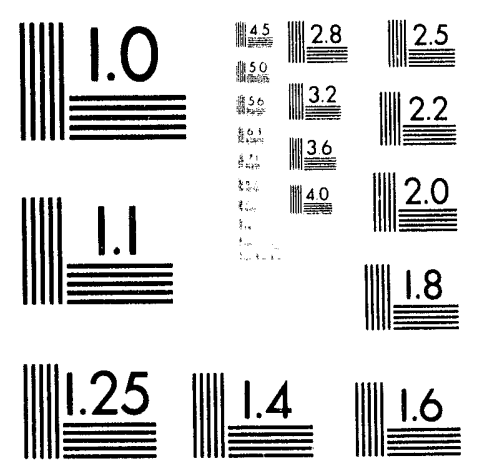



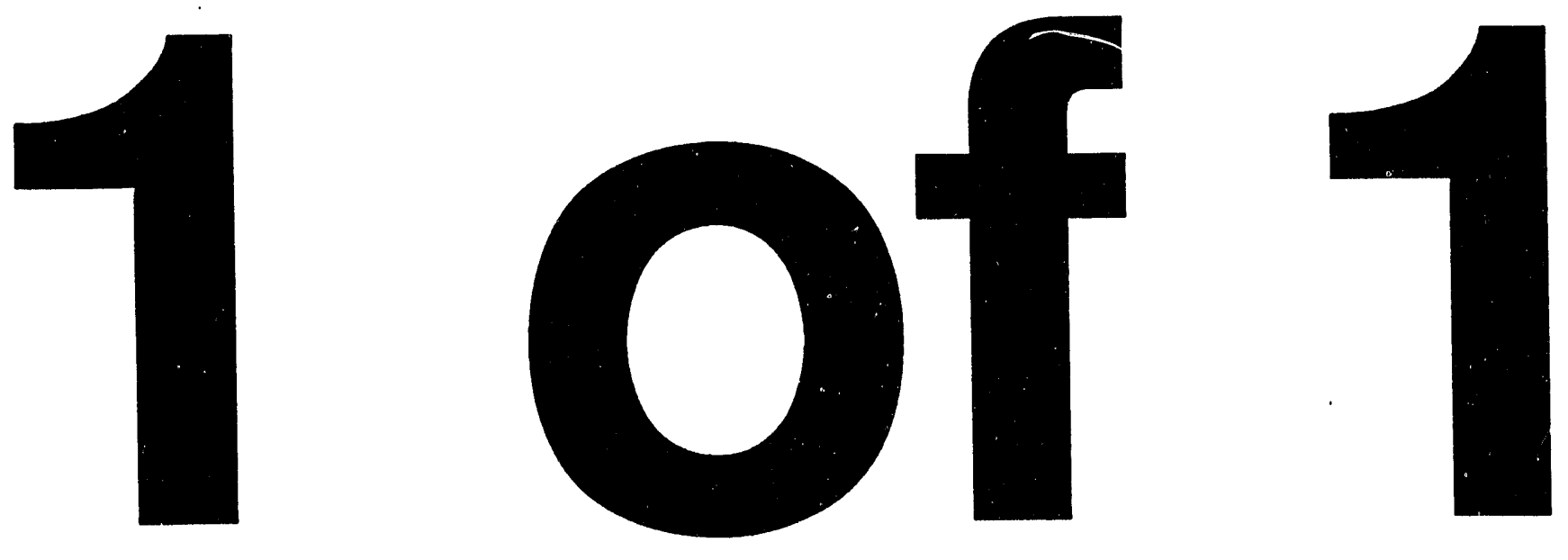
DOE/EIA-0174(92)

Distribution Category UC-950

\title{
Solar Collector Manufacturing Activity 1992
}

\section{November 1993}

\author{
Energy Information Administration \\ Office of Coal, Nuclear, Electric and Alternate Fuels \\ U.S. Department of Energy \\ Washington, DC 20585
}

This report was prepared by the Energy Information Administration, the independent statistical and analytical agency within the Department of Energy. The information contained herein should not be construed as advocating or reflecting any policy position of the Department of Energy or of any other organization. 


\section{Contacts}

Questions regarding the contents of this report may be directed to:

\section{Survey Management Division}

Office of Coal, Nuclear, Electric and Alternate Fuels

Energy Inforriation Administration, EI-52

U.S. Department of Energy

1000 Independence Avenue, SW

Washington, DC 20585
Questions of a general nature should be directed to Howard L. Walton (202/254-5500), Director of the Survey Management Division; Noel Balthasar (202/2545400), Chief, Coal and Uranium Data Systems Branch; or Luther Smith (202/254-5565), Team Leader.

Questions of a technical nature should be directed to Peter Holihan (202/254-5432), Project Manager. 


\section{Preface}

The Solar Collector Manufacturing Activity 1992 report prepared by the Energy Information Administration (EIA) presents data provided by U.S.-based manufacturers and importers of solar collectors. Summary data on solar thermal collector shipments are presented for the years 1974 through $1992 .{ }^{1}$ Summary data on photovoltaic cell and module shipments are presented for the years 1982 through 1992. Detailed information for solar thermal collectors and photovoltaic cells and modules are presented for 1992 . The 1992 data were collected on Form CE-63A, "Annual Solar Thermal Collector Manufacturers Survey," and Form CE-63B, "Annual Photovoltaic Module/Cell Manufacturers Survey." The standard unit of measure for solar thermal collectors is square feet of collector surface and for photovoltaic cells and modules is peak watts (see Glossary).

Appendix A of the report describes the survey methodology. Appendix B contains the 1992 survey forms and instructions. Appendices $C$ and $D$ list the companies that responded to the $1992 \mathrm{CE}-63 \mathrm{~A}$ and CE-63B surveys and granted permission for their names and addresses to appear in the report. Appendix E provides selected tables from this report with data shown in the International System of Units (SI) metric units.
Appendix $\mathrm{F}$ provides an estimate of installed capacity and energy production from solar collectors for 1992.

This report provides annual hata necessary for the Department of Energy to execute its responsibilities to (1) monitor activities in the solar collector industry, (2) implement the National Energy Strategy, and (3) provide information on the development and status of the industry to the Congress, Federal and State government agencies, solar energy manufacturers and specialists, universities and research institutes, and to the general public.

The EIA and its predecessor organizations began conducting voluntary telephone surveys of the solar thermal collector industry in 1975 to monitor manufacturing activities. The first survey collected data for 1974, and subsequent surveys were conducted semi annually through 1981. Since 1982, the surveys have been conducted annually. The sole exception was 1985, when the Form CE-63A survey was not conducted. Mandatory reporting of data or Forms CE-63A and CE-63B was specified under Public L.w 93-275, and it was initiated with the data collection for the period July through December 1978.

\footnotetext{
'Data for 1985 were not collected until 1987 and are considered incomplete. Comparisons of the available 1985 data with similar data for 1984 and 1986 are provided in Appendix A.
} 


\section{Contents}

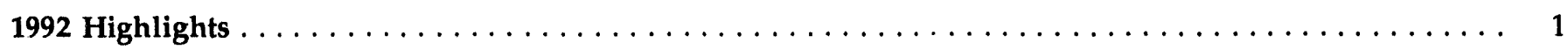

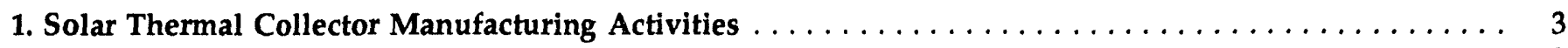

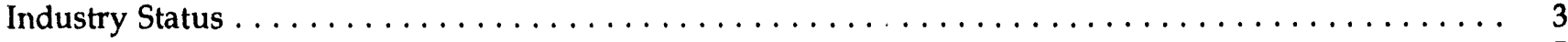

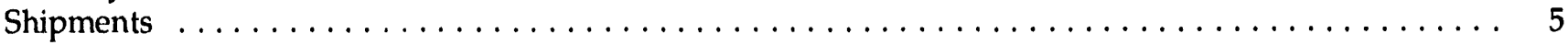

2. Photovoltaic Cell and Module Manufacturing Activities $\ldots \ldots \ldots \ldots \ldots \ldots \ldots \ldots \ldots \ldots \ldots \ldots$

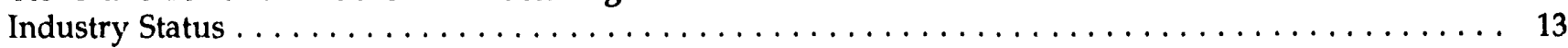

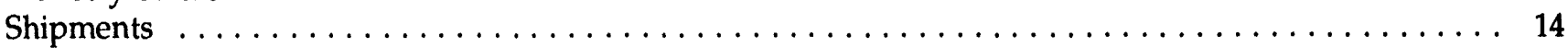

Appendices

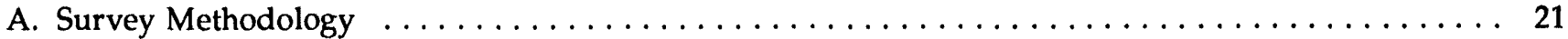

B. CE-63A/B Survey Forms and Instr tions $\ldots \ldots \ldots \ldots \ldots \ldots \ldots \ldots \ldots \ldots \ldots \ldots \ldots \ldots$

C. Respondents to the 1992 Solar Ther nal Collector Manufacturers Survey (Form CE-63A) . . . . . . . 45

D. Respondents to the 1992 Photovoltaic Module/Cell Manufacturers Survey (Form CE-63B) . . . . . . . 49

E. U.S. Customary Units of Measurement, International System of Units (SI), and Selected Data Tables in SI Metric Units $\ldots \ldots \ldots \ldots \ldots \ldots \ldots \ldots \ldots \ldots \ldots \ldots$

F. Solar Collector Installed C. pacity and Ener, : Production in the United States . . . . . . . . . 61

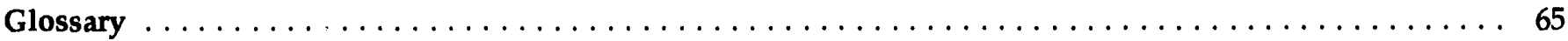




\section{Tables}

1. Annual Solar Thermal Collector Companies and Shipments, $1974-1992 \ldots \ldots \ldots \ldots \ldots \ldots \ldots$

2. Number of Companies Expecting to Introduce New Solar Thermal Collector Products in $1993 \ldots \ldots \ldots$. . . . 4

3. Percent of Solar Thermal Collector Shipments by the Ten Largest Companies, 1982-1992 . . . . . . . . 4

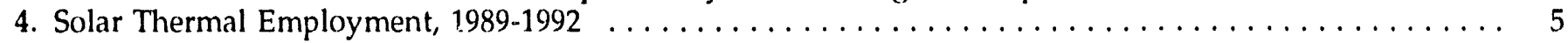

5. Number of Companies Involved in Solar Thermal-Related Activities by Type, 1991 and $1992 \ldots \ldots \ldots$. . . 5

6. Solar-Related Sales as a Percentage of Total Sales, 1991 and $1992 \ldots \ldots \ldots \ldots \ldots \ldots \ldots \ldots \ldots \ldots \ldots$

7. Five Top Solar Thermal Manufacturing States/Territories, 1991 and $1992 \ldots \ldots \ldots \ldots \ldots \ldots \ldots \ldots$

8. Distribution of Solar Thermal Collector Shipments, 1991 and $1992 \ldots \ldots \ldots \ldots \ldots \ldots \ldots \ldots \ldots \ldots$

9. Solar Thermal Collector Shipments by Type, $1980 \cdot 1992 \ldots \ldots \ldots \ldots \ldots \ldots \ldots \ldots \ldots \ldots \ldots \ldots \ldots$

10. Quantity, Value, and Average Price of Solar Thermal Collector Shupments by Type, 1991 and 1992 . . . $\quad 9$

11. Shipments of Solar Thermal Collectors by End Use and Type, 1991 and $1992 \ldots \ldots \ldots \ldots \ldots \ldots \ldots$

12. Shipments of Solar Thermal Collectors by Market and Type, 1991 and $1992 \ldots \ldots \ldots \ldots \ldots \ldots \ldots \ldots$

13. Shipments of Solar Thermal Collectors by Destination, 1991 and $1992 \ldots \ldots \ldots \ldots \ldots \ldots \ldots \ldots \ldots \ldots$

14. The Top Five Destinations of Shipments, 1991 and $1992 \ldots \ldots \ldots \ldots \ldots \ldots \ldots \ldots \ldots \ldots \ldots \ldots \ldots$

15. Distribution of Solar Thermal Collector Exports by Continent, $1992 \ldots \ldots \ldots \ldots \ldots \ldots \ldots \ldots \ldots \ldots \ldots 12$

16. Distribution of Solar Thermal Collector Exports by Country Within Continent, $1992 \ldots \ldots \ldots \ldots \ldots \ldots 12$

17. Complete Solar Thermal Collector Systems Shipped, $1990-1992 \ldots \ldots \ldots \ldots \ldots \ldots \ldots \ldots \ldots \ldots \ldots \ldots . \ldots \ldots$

18. Photovoltaic Cell and Module Companies and Shipments, $1982-1992 \ldots \ldots \ldots \ldots \ldots \ldots \ldots \ldots \ldots$

19. Companies Expecting to Introduce New Photovoltaic Products in $1993 \ldots \ldots \ldots \ldots \ldots \ldots \ldots \ldots \ldots \ldots$

20. Employment in the Photovoltaic Manufacturing Industry, $1989-1992 \ldots \ldots \ldots \ldots \ldots \ldots \ldots \ldots \ldots$

21. Number of Companies Involved in Photovoltaic Related Activities, 1991 and $1992 \ldots \ldots \ldots \ldots \ldots \ldots$

22. Distribution of Photovoltaic Cells and Modules, 1991 and $1992 \ldots \ldots \ldots \ldots \ldots \ldots \ldots \ldots \ldots \ldots \ldots$

23. Photovoltaic Cell and Module Shipments by Type, $1990-1992 \ldots \ldots \ldots \ldots \ldots \ldots \ldots \ldots \ldots \ldots \ldots$

24. Value and Average Price of Cells and Modules by Type, 1991 and $1992 \ldots \ldots \ldots \ldots \ldots \ldots \ldots \ldots$

25. Shipments of Photovoltaic Cells and Modules by End Use and Type, 1991 and $1992 \ldots \ldots \ldots \ldots \ldots \ldots$

26. Shipments of Photovoltaic Cells and Modules by Market and Type, 1991 and $1992 \ldots \ldots \ldots \ldots \ldots \ldots$

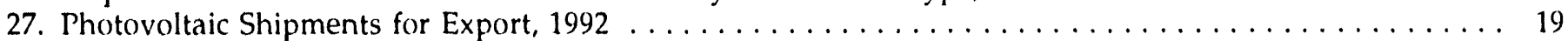

28. Destination of Photovoltaic Cell and Module Exports by Continent, $1992 \ldots \ldots \ldots \ldots \ldots \ldots \ldots \ldots$

29. Destination of Photovoltaic Cell and Module Exports by Countries Receiving Exports, $1992 \ldots \ldots \ldots$

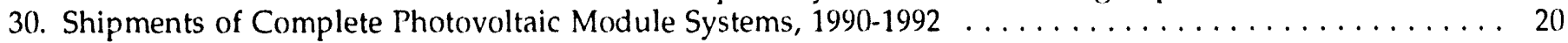

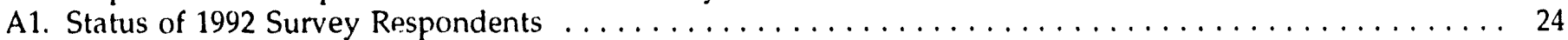

A2. Number of Reporting Companies and Shipments, 1984, 1985, and $1986 \ldots \ldots \ldots \ldots \ldots \ldots \ldots \ldots \ldots$

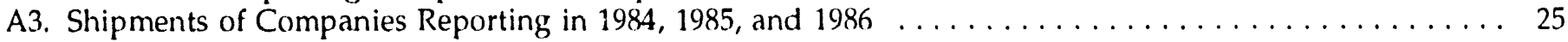

A4. Imputed Solar Thermal Collector Shipments, $1980-1983 \ldots \ldots \ldots \ldots \ldots \ldots \ldots \ldots \ldots \ldots \ldots \ldots \ldots 25$

E1. Conversion Factor for U.S. Customary Units and SI Metric Units of Measurement $\ldots \ldots \ldots \ldots \ldots \ldots 5$

E2. Solar Thermal Collector Companies and Shipments, $1974-1992 \ldots \ldots \ldots \ldots \ldots \ldots \ldots \ldots \ldots \ldots$

E3. Five Top Solar Thermal Manufacturing States/Territories, 1991 and $1992 \ldots \ldots \ldots \ldots \ldots \ldots \ldots \ldots$. . . . . 56

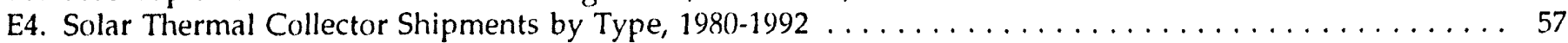

E5. Quantity, Value, and Average Price of Solar Thermal Collector Shipments by Type, 1991 and 1992 . . . 58

E6. Shipments of Solar Thermal Collectors by End Use and Type, 1991 and $1992 \ldots \ldots \ldots \ldots \ldots \ldots$

E7. Shipments of Solar Thermal Collectors by Market and Type, 1991 and $1992 \ldots \ldots \ldots \ldots \ldots \ldots$. . . . . . . . . . . .

E8. Shipments of Solar Thermal Collectors by Destination, 1991 and $1992 \ldots \ldots \ldots \ldots \ldots \ldots \ldots \ldots$. . . . . . . 60

F1. Annual Photovoltaic and Solar Thermal Dornestic Shipments, $1974-1992 \ldots \ldots \ldots \ldots \ldots \ldots \ldots \ldots \ldots$

F2. U.S. Utility Net Electricity Generation from Solar Energy, $1992 \ldots \ldots \ldots \ldots \ldots \ldots \ldots \ldots \ldots \ldots \ldots \ldots 64$

F3. Estimated U.S. Solar and Total Energy Production, $1992 \ldots \ldots \ldots \ldots \ldots \ldots \ldots \ldots \ldots \ldots \ldots \ldots \ldots$ 


\section{Figures}

1. Solar Thermal Collector Shipments, $1978-1992 \ldots \ldots \ldots \ldots \ldots \ldots \ldots \ldots \ldots \ldots \ldots \ldots \ldots \ldots$

2. Low- and Medium-Temperature Solar Thermal Collector Shipments, $1980-1992 \ldots \ldots \ldots \ldots \ldots \ldots \ldots$. . . 8

3. Average Price of Solar Thermal Collectors, 1991 and $1992 \ldots \ldots \ldots \ldots \ldots \ldots \ldots \ldots \ldots \ldots \ldots \ldots$

4. Photovoltaic Cell and Module Shipments, $1985-1992 \ldots \ldots \ldots \ldots \ldots \ldots \ldots \ldots \ldots \ldots \ldots \ldots \ldots \ldots 14$

5. Photovoltaic Cell and Module Shipments by Type, $1989-1992 \ldots \ldots \ldots \ldots \ldots \ldots \ldots \ldots \ldots \ldots \ldots \ldots$

6. Average Price of Photovoltaic Modules, $1990-1992 \ldots \ldots \ldots \ldots \ldots \ldots \ldots \ldots \ldots \ldots \ldots \ldots \ldots$ 


\section{Highlights}

Solar thermal collector shipments totaled 7.1 million square feet in 1992, compared with 6.6 million square feet in 1991. An 11-percent increase in shipments of low-temperature collectors, used primarily to heat residential swimming pools, was responsible for this growth. Shipments of low-temperature collectors increased in 1992 to 6.2 million square feet from 5.6 million square feet in 1991. Shipments of mediumtemperature collectors declined from 1 million square feet in 1991 to 0.9 million square feet in 1992, a 9 percent decrease (Figure H1). The number of companies that shipped solar thermal collectors also declined

\section{Figure H1. Solar Thermal Collector Shipments by Collector Type, 1981-1992}

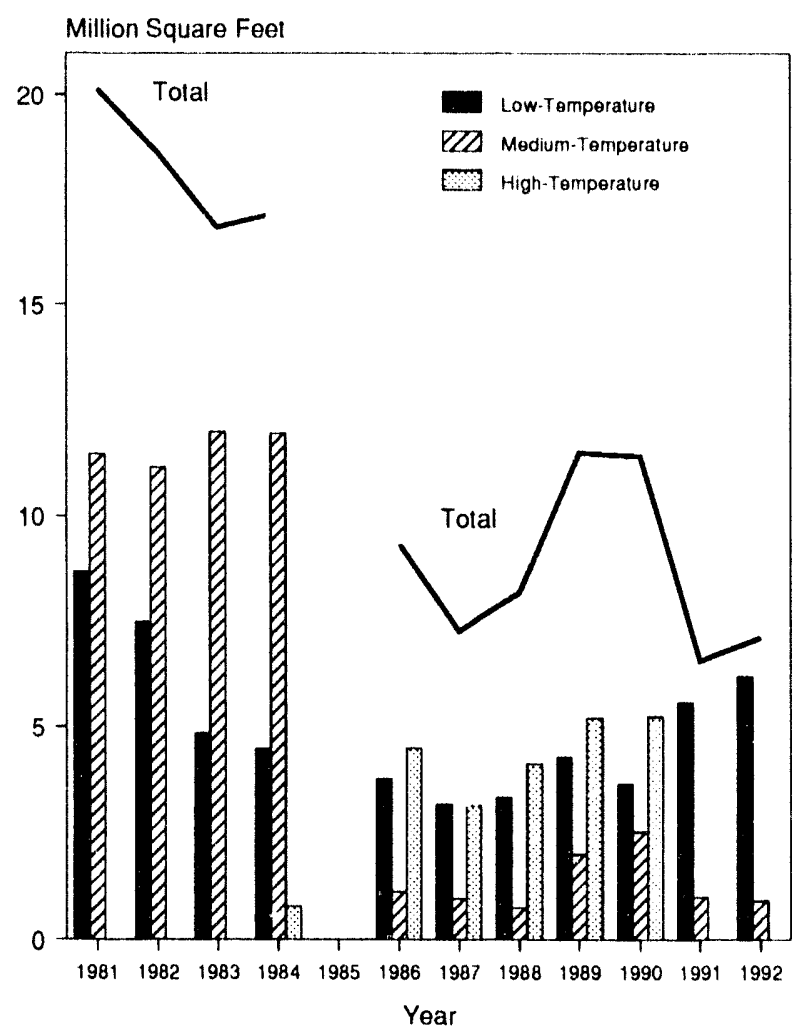

Note: Data for 1985 are incomplete and are not shown. Sources: 1981-1984-Energy Information Administration, Form EIA-63, "Annual Solar Thermal Collector and Photovoltaic Module Manufacturers Survey." 1985-1992-Energy Information Administration, Form CE-63A, "Annual Solar Thermal Collector Manufacturers Survey." from 48 in 1991 to 45 in 1992, the same number as in 1974.

The total value of solar thermal collector shipments in 1992 was $\$ 25.4$ million, a 9-percent decrease from 1991. This decrease was due in part to a drop in the average price per square foot of low-temperature collectors, which decreased 14 percent to $\$ 2.49$ per square foot in 1992 from $\$ 2.90$ per square foot in 1991.

For the last 4 years (1989-1992), solar thermal collector shipments to the commercial sector have been declining, while shipments to the residential sector have been steadily increasing. Shipments of low-temperature solar thermal collectors have experienced an overall increase from 1990 through 1992, but shipments in that same period of medium-temperature solar thermal collectors have declined.

A.t the end of 1992, 27 States provided some financial incentives for investment in the use of solar thermal collectors and photovoltaic modules and cells, compared with 15 States in 1991. The legislative actions were passed to encourage the use of an environmentally clean source of energy, to promote energy conservation through the use of renewable energy technologies, and to increase energy efficiency. Among the most common incentives were property tax exemptions and income tax credits for both the residential and business sectors.

In 1992, California, New York, New Jersey, Florida, and Puerto Rico accounted for 98 percent of the total manufacturing of solar thermal collectors. California accounted for more than 50 percent of the total number of solar thermal collectors manufactured in both 1991 and 1992. Industry wide, the top five destinations for shipments were Florida, California, Arizona, Hawaii, and Puerto Rico. Florida and California together received 83 percent of all shipments to U.S. and U.S. territories.

Shipments of photovoltaic cells and modules (Figure H2) totaled 15.6 peak megawatts in 1992, an increase of 4 percent, compared with the 14.9 peak megawatts in 1991. The total value of photovoltaic cell and module shipments in 1992 was $\$ 87.1$ million, a small increase from the value of shipments in 1991 ( $\$ 86.7$ million). 
Figure H2. Domestic and Export Shlpments of Photovoltalc Cells and Modules, 1985-1992

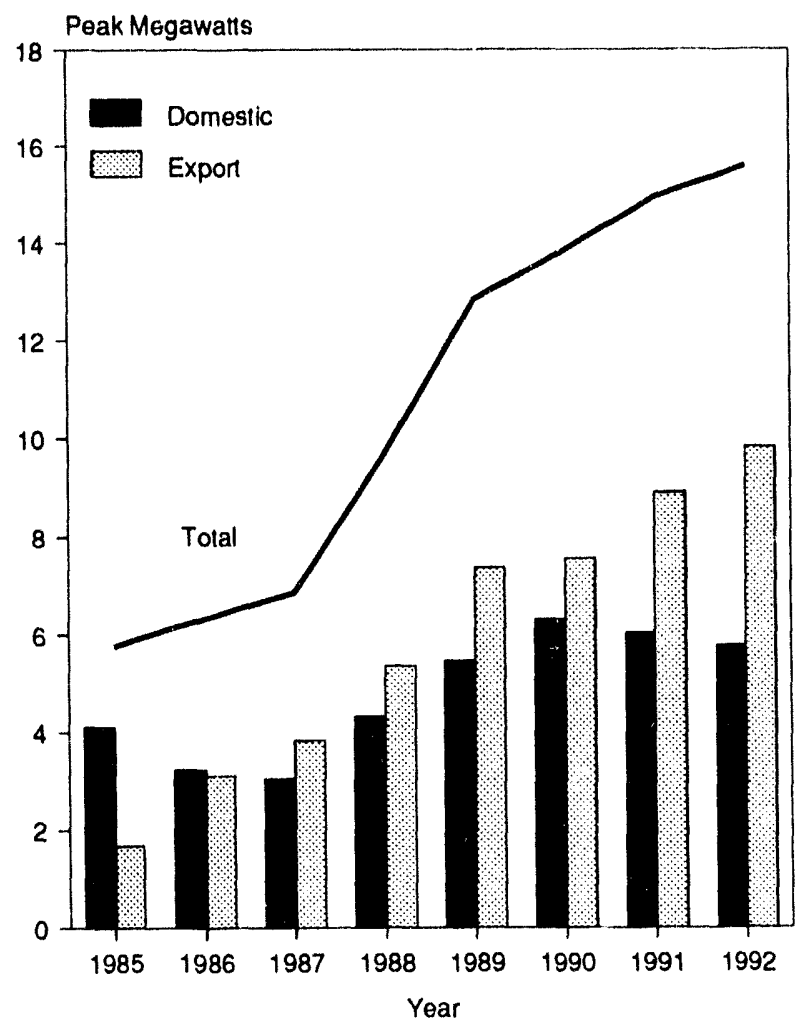

Approximately 10 peak megawatts were exported in 1992, an increase of 10 percent from the 1991 level. Since 1987, the annual amount of export shipments has exceeded domestic shipments.

Shipments of photovoltaic cells and modules for the period 1988 through 1992 have been increasing at an average annual rate of 10 percent. Shipments to the commercial sector have declined 61 percent since 1990, but shipments to the residential sector have increased 40 percent over the same period of time. The average price (dollars per peak watt) of all types of photovoltaic modules has decreased slightly since 1985 mainly as a result of a marked decline in the average price of concentrator modules and cells. This decline was mainly due to increased volumes of shipments of concentrators in 1992.

EIA estimates that solar thermal collectors and photovoltaic modules and cells provided approximately 0.06 quadrillion Btu of energy production in the United States during 1992 (see Appendix F).

Note: Domestic shipments equal total shipments minus exports.

Source: Energy Information Administration, Form CE-63B, "Annual Photovoltaic Module/Cell Manufacturers Survey."

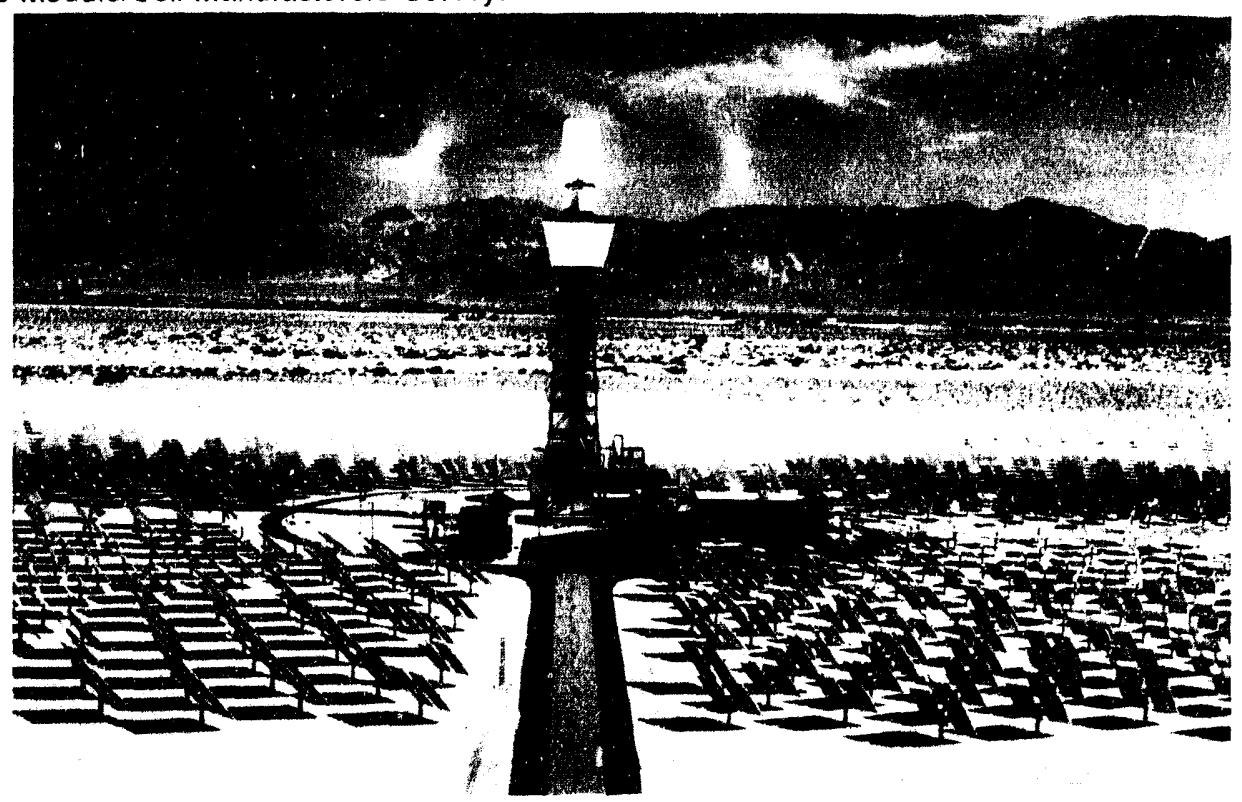

Solar Two is a 10-megawatt central receiver pilot plant in Barstow. California. This project, led by Southern California Edison, is cost-shared by DOE, several major western utilities, EPRI. Bechtel, and the South Coast Air Quality Management District. 


\section{Solar Thermal Collector Manufacturing Activities}

This chapter presents information on the statistics of the solar thermal collector manufacturing industry in 1992. Solar thermal collector shipments, origins and destinations, imports, exports, collector types, values and prices, and uses and market sectors are presented. Data on solar thermal collector shipments include both imported collectors and collectors manufactured by U.S.-based companies that were shipped for domestic use and for export.

\section{Industry Status}

Forty-five companies were active in the solar thermal collector manufacturing industry in 1992. These 45 companies shipped collectors totaling 7.1 million square feet in 1992 (Table 1). Of the 45 companies, 5 plan to introduce new high-temperature collectors in 1993, and 12 plan to introduce new medium-temperature collectors (Table 2).

From 1984 to 1986 , the number of manufacturing companies declined by 127 (Table 1). At the end of 1985 the 40-percent residential energy tax credit and the 15percent business energy tax credit expired. The decline in industry companies intensified with the drop in oil prices in 1986. The reinstatement of the business energy tax credit at the 15-percent level for 1986, at the 12percent level for 1987 through 1991, and at the 10percent level in 1992, plus increasing oil prices after

Table 1. Annual Solar Thermal Collector Companies and Shlpments, 1974-1992

(Thousand Square Feet)

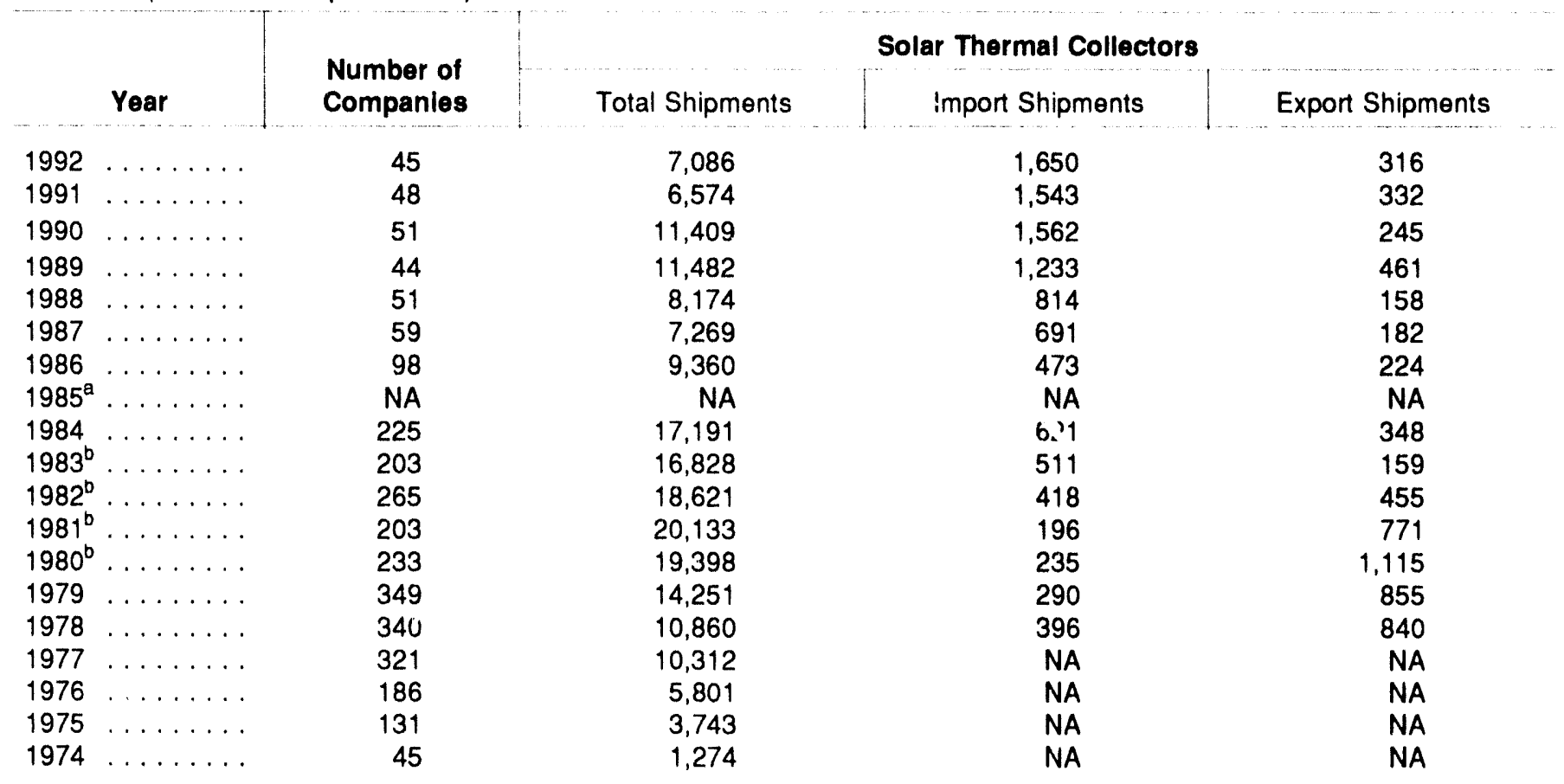

Incomplete data (see Appendix A).

blicludes imputation of shipment data to account for nonrespondents (see Appendix A, pages 24 and 25).

NA $=$ Not available.

Note: Total shipments include import and export shipments.

Sources: 1974-1977-Federal Energy Administration telephune survey. 1978-1984-Energy Information Administration, Form EIA-63, "Annual Solar Thermal Collector and Photovoltaic Module Manufacturers Survey." 1985-1992-Energy Information Administration, Form CE-63A, "Annual Solar Thermal Collector Manufacturers Survey." 
Table 2. Number of Companies Expecting to Introduce New Solar Thermal Collector Products in 1993

\begin{tabular}{c|c} 
New Product Type & $\begin{array}{c}\text { Number of } \\
\text { Compenles }\end{array}$ \\
\hline Low-Temperature Collectors $\ldots \ldots \ldots \ldots$ & 5 \\
Medium-Temperature Collectors $\ldots \ldots \ldots$ & 12 \\
High-Temperature Collectors $\ldots \ldots \ldots$ & 5 \\
Non-Collector Components $\ldots \ldots \ldots \ldots$ & 5 \\
\hline Source: Energy Information Administration, Form \\
CE-63A, "Annual Solar Thermal Collector Manufacturers \\
Survey."
\end{tabular}

1986 appear to have had little effect on drawing companies into manufacturing solar thermal collectors.

At the end of 1992, 27 States provided some financial incentives for investment in the use of solar thermal collectors and photovoltaic modules and cells, compared with 15 States in $1991 .^{2}$ The legislative actions were passed to encourage the use of an environmentally clean source of energy, to promote energy conservation through the use of renewable energy technologies, and to increase energy efficiency. Among the most common incentives were property tax exemptions and income tax credits for both the residential and business sectors.

For the period 1986-1991, the 10 largest U.S. companies in terms of collector shipments have supplied between 91 and 97 percent of all solar thermal collecturs manufactured in or imported into the United States (Table 3). In 1992, 95 percent of the 7.1 million square feet of total shipments were supplied by the 10 largest companies. In the period 1982 to 1984, the average share of the 10 largest companies was 50 percent of total shipments.

Employment in solar thermal-related activities totaled 449 person-years in 1992 (Table 4), an increase of 111 person-years from the 1991 employment level. The average employment per company was 10 person-years, compared with 7 person-years in 1991. For 1992, the range in employment levels for about 50 percent of the companies was 1 to 5 person-years.

Most of the 45 reporting companies in 1992 combined other related activities with the manufacturing or importing of solar thermal collectors: 35 companies were involved in collector or system design, 18
Table 3. Percent of Solar Thermal Collector Shipments by the Ten Largest Companies, 1982-1992

\begin{tabular}{|c|c|c|c|c|}
\hline & lear & $\begin{array}{c}\text { Company } \\
\text { Rank }\end{array}$ & $\begin{array}{c}\text { Shipmenty } \\
\text { (thousand } \\
\text { square feet) }\end{array}$ & $\begin{array}{c}\text { Percent of } \\
\text { Total } \\
\text { Shipments }\end{array}$ \\
\hline 1992. & $\ldots \ldots$ & $\begin{array}{l}1-5 \\
6 \cdot 10 \\
1-10\end{array}$ & $\begin{array}{r}6,110 \\
609 \\
6,718\end{array}$ & $\begin{array}{r}86 \\
9 \\
95\end{array}$ \\
\hline 1991. & $\ldots \ldots$ & $\begin{array}{l}1-5 \\
6-10 \\
1-10\end{array}$ & $\begin{array}{r}5,429 \\
829 \\
6,258\end{array}$ & $\begin{array}{l}83 \\
13 \\
95\end{array}$ \\
\hline 1990 & $\ldots \ldots$ & $\begin{array}{l}1-5 \\
6-10 \\
1-10\end{array}$ & $\begin{array}{r}9,955 \\
1,029 \\
10,983\end{array}$ & $\begin{array}{r}87 \\
9 \\
96\end{array}$ \\
\hline 1989. & $\ldots \ldots$ & $\begin{array}{l}1-5 \\
6-10 \\
1-10\end{array}$ & $\begin{array}{r}9,748 \\
1,321 \\
11,069\end{array}$ & $\begin{array}{l}85 \\
12 \\
96\end{array}$ \\
\hline 1988 & $\ldots \ldots$ & $\begin{array}{l}1-5 \\
6-10 \\
1-10\end{array}$ & $\begin{array}{r}7,585 \\
335 \\
7,920\end{array}$ & $\begin{array}{r}93 \\
4 \\
97\end{array}$ \\
\hline 1987. & $\ldots \ldots$ & $\begin{array}{l}1-5 \\
6-10 \\
1-10\end{array}$ & $\begin{array}{r}6,371 \\
499 \\
6,870\end{array}$ & $\begin{array}{r}88 \\
7 \\
95\end{array}$ \\
\hline$: 980$. & $\ldots \ldots$ & $\begin{array}{l}1-5 \\
6-10 \\
1-10\end{array}$ & $\begin{array}{r}7,771 \\
785 \\
8,556\end{array}$ & $\begin{array}{r}83 \\
8 \\
91\end{array}$ \\
\hline $1985^{a}$ & $\ldots \ldots$ & .. & NA & $\cdot-$ \\
\hline 1984 & $\ldots \ldots$ & $\begin{array}{l}1-5 \\
6-10 \\
1-10\end{array}$ & $\begin{array}{l}6,092 \\
2,605 \\
8,697\end{array}$ & $\begin{array}{l}35 \\
15 \\
51\end{array}$ \\
\hline 1983 & $\ldots$ & $\begin{array}{l}1-5 \\
6-10 \\
1-10\end{array}$ & $\begin{array}{l}5,919 \\
2,752 \\
8,671\end{array}$ & $\begin{array}{l}35 \\
16 \\
52\end{array}$ \\
\hline 1982 & $\ldots \ldots$ & $\begin{array}{l}1-5 \\
6-10 \\
1-10\end{array}$ & $\begin{array}{l}6,320 \\
2,560 \\
8,880\end{array}$ & $\begin{array}{l}34 \\
14 \\
48\end{array}$ \\
\hline
\end{tabular}

Incomplete data (see Appendix A, pages 24 and 25). $N A=$ Not available. $\cdots=$ Not applicable.

Note: Totals may not equal sum of components due to independent rounding.

Sources: 1982-1984-Energy Information Administration, Form EIA-63, "Annual Solar Thermal Collector and Photovoltaic Module Manufacturers Survey." 1985-1992-Energy Information Administration, Form CE-63A, "Annual Solar Thermal Collector Manufacturers Survey."

manufacturers were developing prototype collectors, and 20 were developing prototype systems (Table 5). Twenty-four companies were wholesalers, and $24 \mathrm{com}$ panies were retailers. Twenty of the 45 companies installed their collectors. 
Table 4. Solar Thermal Employment, 1989-1992

\begin{tabular}{|c|c|c|}
\hline Year & $\begin{array}{l}\text { Number of } \\
\text { Companles }\end{array}$ & $\begin{array}{l}\text { Number of } \\
\text { Person-Yoars }\end{array}$ \\
\hline $\begin{array}{l}1992 \ldots \ldots \ldots \\
1991 \ldots \ldots \ldots \\
1990 \ldots \ldots \ldots \ldots \\
1989 \ldots \ldots \ldots \ldots\end{array}$ & $\begin{array}{l}{ }^{a} 45 \\
48 \\
51 \\
44\end{array}$ & $\begin{array}{l}449 \\
338 \\
850 \\
900\end{array}$ \\
\hline
\end{tabular}

${ }^{a}$ One company reported zero employment.

Source: Energy Information Administration, Form CE-63A, "Annual Solar Thermal Collector Manufacturers Survey."

Table 5. Number of Companles Involved in Solar Thermal-Related Activities by Type, 1991 and 1992

\begin{tabular}{|c|c|c|}
\hline \multirow[b]{2}{*}{ Type of Activity } & \multicolumn{2}{|c|}{$\begin{array}{l}\text { Number of } \\
\text { Companles }\end{array}$} \\
\hline & 1992 & 199 \\
\hline $\begin{array}{l}\text { Collector or System Design ........ } \\
\text { Prototype Collector Development . . . } \\
\text { Prototype Systems Development . . }\end{array}$ & $\begin{array}{l}35 \\
18 \\
20\end{array}$ & \\
\hline $\begin{array}{l}\text { Wholesale Distribution } \ldots \ldots \ldots \ldots \\
\text { Retail Distribution } \ldots \ldots \ldots \ldots \ldots \ldots \\
\text { Installation } \ldots \ldots \ldots \ldots \ldots \ldots \ldots \ldots\end{array}$ & $\begin{array}{l}24 \\
24 \\
20\end{array}$ & \\
\hline $\begin{array}{l}\text { Non-Collector System } \\
\text { Component Manufacture }\end{array}$ & 16 & \\
\hline
\end{tabular}

Source: Energy Information Administration, Form CE-63A, "Annual Solar Thermal Collector Manufacturers Survey."

Solar-related sales represented 90 to 100 percent of total company sales for 27 companies in 1992 versus 26 companies in 1991 (Table 6). Solar-related sales made up less than 10 percent of total sales for 4 companies in 1992, compared with 8 companies in 1991.

\section{Shipments}

Solar thermal collector shipments totaled 7.1 million square feet in 1992, an 8-percent increase from the 1991 level of 6.6 million square feet in 1991 (Table 1). Import shipments totaled 1.7 million square feet and export shipments were 0.3 million square feet in 1992 (Figure 1). Shipments of low-temperature solar thermal collectors increased 11 percent in 1992 from 1991, and medium-temperature collectors decreased 9 percent. Shipments of high-temperature collectors increased from 1,000 square feet in 1991 to 2,000 square feet in 1992 (Table 9).

\section{Table 6. Solar-Related Sales as a Percentage of Total Sales, 1991 and 1992}

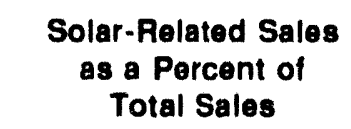

$90-100 \ldots \ldots \ldots \ldots$

$50-89 \ldots \ldots \ldots \ldots$

$10-49 \ldots \ldots \ldots \ldots$

Less than 10

Total $\ldots \ldots \ldots \ldots \ldots$

\section{Number of Companies \\ 1992 \\ 1991}

$\begin{array}{rr}27 & 26 \\ 7 & 9 \\ 7 & 5 \\ 4 & 8\end{array}$

45
Source: Energy Information Administration, Form CE-63A, "Annual Solar Thermal Collector Manufacturers Survey."

\section{Origins}

U.S. manufacturers in California, New York, New Jersey, Florida and Puerto Rico produced 98 percent of U.S.-manufactured cullectors in 1992, compared with 99 percent in 1991. California continued to lead the Nation in 1992, with 55 percent of total domestic shipments. Shipments of U.S. manufactured solar thermal collectors in 1992, which totaled 5.4 million square feet, originated Irom 19 States and Puerto Rico. California produced 55 percent of U.S. manufactured solar thermal collectors in 1992 compared with 56 percent in 1991 (Table 7). New York, New Jersey, and Florida produced a combined 2.2 million square feet in 1992. The amount of collectors produced in Florida increased from 149,000 square feet in 1991 to 208,000 square feet in 1992, a 40-percent increase. Hawaii and Texas had shipments of over 10,000 square feet in 1992.

\section{Distribution}

Fifty percent of total shipments were seni directly to wholesale distributors and 38 percent were sent to retail distributors in 1992 (Table 8). Eighty-nine percent of export shipments were sent directly to exporters. Fight percent of total shipments were shipped directly to installers, end users, or "others."

\section{Collector Types}

Solar thermal collectors are divided into three categories:

- Low-temperature collectors provide heat up to $110^{\circ}$ Fahrenheit through either metallic or nonmetallic absorbers for applications such as 
Figure 1. Solar Thermal Coliector Shlpments, 1978-1992

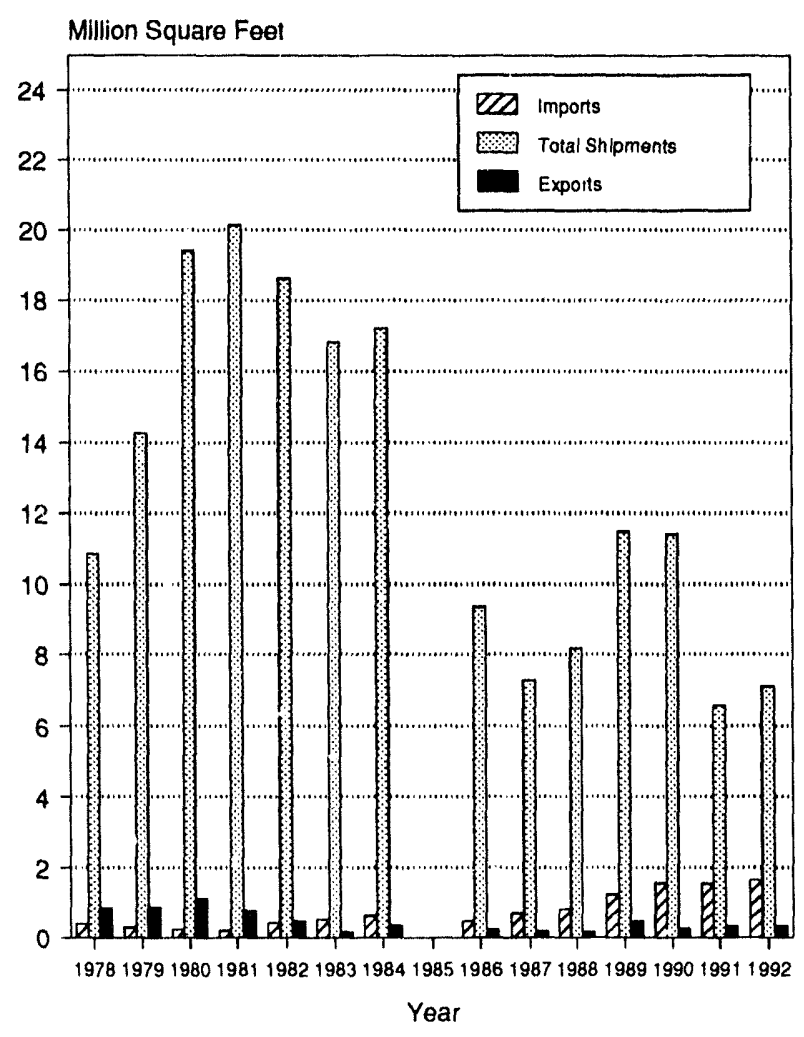

Note: Data for 1985 are incomplete and are not shown. Sources: 1978-1984-Energy information Administration, Form EIA-63, "Annual Solar Thermal Collector and Photovoltaic Module Manufacturers Survey." 1985-1992-Energy Information Administration, Form CE-6iA, "Annual Solar Thermal Collector Manufacturers Survey."

swimming pool heating and water, space, and process heating.

- Medium-temperature collectors provide heat greater than $110^{\circ}$ Fahrenheit (usually 140 to $180^{\circ}$ Fahrenheit) through either glazed flat-plate collectors that use air or liquid as the heat transfer medium or concentrator collectors that concentrate the heat to levels greater than "one sun." Evacuated-tube collectors are included in this category.

- High-temperature collectors are parabolic dish or trough collectors used primarily by utilities and nonutility power producers in the generation of electricity for the grid. A high-temperature solar thermal collector is a collector that uperates at temperatures above 180 degrees Fahrenheit.
Table 7. Five Top Solar Thermal Manufacturing States/Territories, 1991 and 1992

(Thousand Square Feet)

\begin{tabular}{|c|c|c|c|c|c|}
\hline \multirow{2}{*}{$\begin{array}{c}\text { Rank } \\
1992 / 1991\end{array}$} & \multirow[b]{2}{*}{ Origin } & \multicolumn{2}{|c|}{ Shipments ${ }^{a}$} & \multicolumn{2}{|c|}{ Percent } \\
\hline & & 1992 & 1991 & 1992 & 1991 \\
\hline $1 / 1$ & California & 2,985 & 2,818 & 55 & 56 \\
\hline $2 / 2$ & New York & 978 & 979 & 18 & 19 \\
\hline $3 / 3$ & New Jersey & 967 & 805 & 18 & 16 \\
\hline $4 / 5$ & Florida & 208 & 149 & 4 & 3 \\
\hline $5 / 4$ & Puerto Rico & 201 & 208 & 4 & 4 \\
\hline \multicolumn{2}{|l|}{ Subtotal } & 5,339 & 4,959 & 98 & 99 \\
\hline \multicolumn{2}{|c|}{ Total U.S. Manufacturers } & 5,436 & 5,031 & 100 & 100 \\
\hline
\end{tabular}

${ }^{2}$ Includes domestic shipments and exports.

Note: Totals may not equal sum of components due to independent rounding.

Source: Energy Information Administration, Form CE-63A,

"Annual Solar Thermal Collector Manufacturers Survey."

Table 8. Distribution of Solar Thermal Collector Shipments, 1991 and 1992

\begin{tabular}{|c|c|c|}
\hline \multirow[b]{2}{*}{ Reciplent } & \multicolumn{2}{|c|}{$\begin{array}{c}\text { Shlpments } \\
\text { (thousand square feet) }\end{array}$} \\
\hline & 1992 & 1991 \\
\hline Wholesale Distributors & 3,537 & 3,674 \\
\hline Retail Distributors & 2,709 & 2,161 \\
\hline Exporters & 280 & 324 \\
\hline Installers & 192 & 191 \\
\hline End Users and Other ${ }^{a}$ & 367 & 224 \\
\hline Total & 7,086 & 6,574 \\
\hline
\end{tabular}

aOther includes minimal shipments not explained on Form CE$63 A$.

Note: Totals may not equal sum of components due to independent rounding.

Source: Energy Information Administration, Form CE-63A, "Annual Solar Thermal Collector Manufacturers Survey."

The average annual shipment of low-temperature collectors was 386,700 square feet per manufacturer for 16 manufacturers in 1992 (Table 9). In 1981, 75 companies manufactured low-temperature collectors, and the average annual shipment was 115,700 square feet per manufacturer. For the 34 medium-temperature collector manufacturers in 1992, the average annual shipment was 26,400 square feet. Ten years earlier, there were 248 manufacturers of medium-temperature 
Table 9. Solar Thermal Collector Shipments by Type, 1980-1992 (Thousand Square Feet)

\begin{tabular}{|c|c|c|c|c|c|}
\hline \multirow[b]{2}{*}{ Yes } & \multicolumn{2}{|c|}{ Low-Temperature } & \multicolumn{2}{|c|}{ Med!um-Temperature } & \multirow{2}{*}{$\begin{array}{c}\text { High-Temperature } \\
\text { Shipments }\end{array}$} \\
\hline & Shipments & $\begin{array}{l}\text { Average Annual } \\
\text { Shipments per } \\
\text { Manufacturer }\end{array}$ & Shipments & $\begin{array}{l}\text { Average Annual } \\
\text { Shipments par } \\
\text { Manufacturer }\end{array}$ & \\
\hline $1992 \ldots$ & 6,187 & 386.7 & 897 & 26.4 & 2 \\
\hline $1991 \ldots$ & 5,585 & 349.0 & 989 & 24.1 & 1 \\
\hline $1990 \ldots$ & 3,645 & 303.8 & 2,527 & 61.6 & 5,237 \\
\hline $1989 \ldots$ & 4,283 & 428.3 & 1,989 & 55.3 & 5,209 \\
\hline 1988 & 3,326 & 415.8 & 732 & 16.2 & 4,116 \\
\hline 1987 & 3,157 & 263.1 & 957 & 19.1 & 3,155 \\
\hline 1986 & 3,751 & 170.5 & 1,111 & 12.8 & 4,498 \\
\hline $1985^{\mathrm{b}}$ & NA & -- & NA & -- & NA \\
\hline 1984 & 4,479 & 93.3 & 11,939 & 58.0 & 773 \\
\hline $1983^{\mathrm{C}}$ & 4,853 & 88.2 & 11,975 & 66.9 & NA \\
\hline $1982^{c}$ & 7,476 & 122.6 & 11,145 & 44.9 & NA \\
\hline $1981^{\mathrm{C}}$ & 8,677 & 115.7 & 11,456 & 43.6 & NA \\
\hline $1980^{c}$ & 12,233 & 154.8 & 7,165 & 28.7 & NA \\
\hline
\end{tabular}

${ }^{a}$ For high-temperature collectors, average annual shipments per manufacturer are not disclosed.

Incomplete data (see Appendix A, pages 24 and 25).

'Includes shipment data imputed for nonrespondents (see Appendix A, pages 24 and 25).

NA $=$ Not available. $--=$ Not applicable.

Note: Totals may not equal sum of components due to independent rounding.

Sources: 1980-1984-Energy Information Administration, Form ElA-63, "Annual Solar Thermal Collector and Photovoltaic Module Manufacturers Survey." 1985-1992-Energy Information Administration, Form CE-63A, "Annual Solar Tinermal Collector Manufacturers Survey."

collectors in the United States, and the average annual shipment was 44,900 square feet.

In 1983 and 1984, before the expiration of the energy tax credits at the end of 1985 , medium-temperature collector manufacturers shipped just under 12 million square feet annuaily (Figure 2). Shipments declined to 1.1 million square feet in 1986. For the period 19861992 , shipments of medium-temperature collectors have ranged between 0.7 and 2.6 million square feet annually.

Between 1980 and 1984, annual low-temperature collector shipments decreased from 12.2 million to 4.5 million square feet. From 1986 through 1992, shipments of lowtemperature collectors ranged between 3.2 and 6.2 million square feet annually. Low-temperature collectors dominated the solar thermal industry in 1992, arcounting for 87 percent of total shipments (Table 9).

Medium-temperature collectors accounted for 13 percent total collector shipments in 1992. Flat plate collectors represented 8 percent of total shipments.
Collectors that constituted sub units of thermosiphon systems or integral collector storage systems (ICS) represented 4 percent of total shipments. Hightemperature collectors, shipped primarily for research and demonstration, represented a negligible percentage of total shipments in 1992.

\section{Values and Prices}

The total value of solar thermal collector shipments was $\$ 25.4$ million in 1992; a "-percent decrease compared with 1991 (Table 10). The average price of lowtemperature collectors decreased from $\$ 2.90$ to $\$ 2.49$ (dollars per square foot), and the average price of ICS and thermosiphon collectors decreased from $\$ 19.08$ in 1991 to $\$ 12.64$ in 1992 . This decrease is most likely due to increased levels of shipments and concurrent lower unit costs. The average price for flat-plate collectors in 1992 increased to $\$ 9.32$ from the corresponding 1991 level of $\$ 9.07$ per square foot (Figure 3 ). The value of shipments includes charges for advertising and warranties. Not included are excise taxes and the cost of freight or transportation for the shipments. 
Figure 2. Low- and Medlum-Temperature Solar Thermal Collector Shipments, 1980-1992

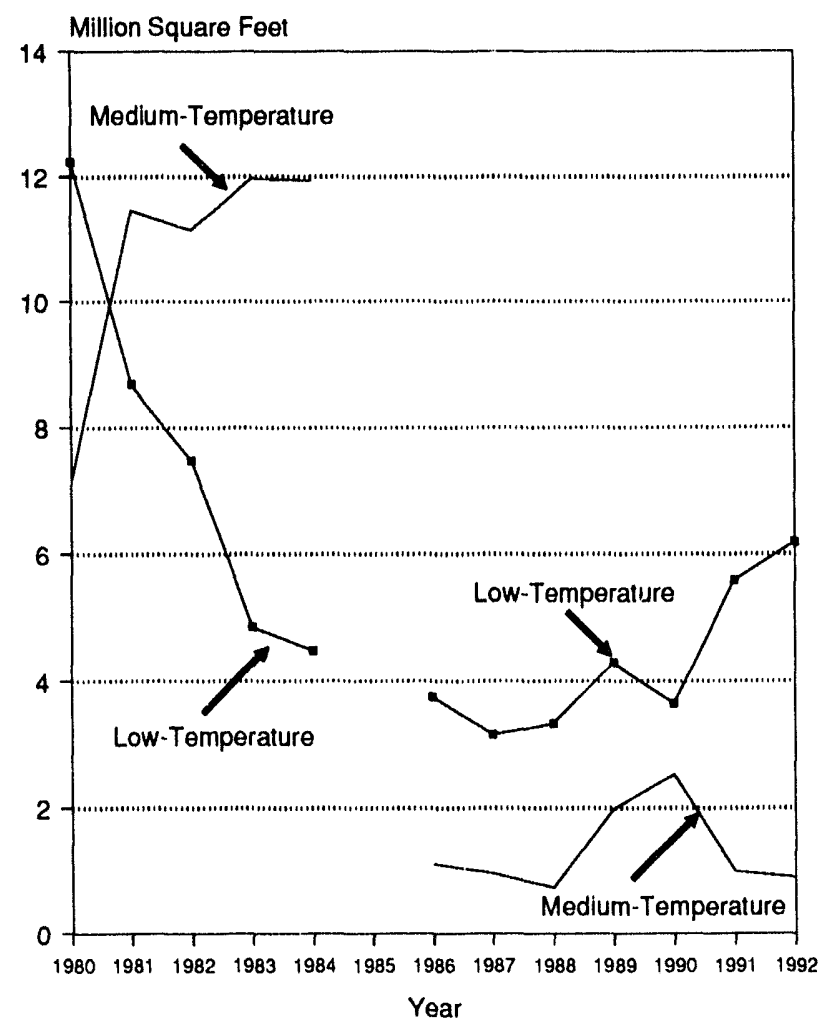

Note: Data for 1985 are incomplete and are not shown. Sources: 1980-1984-Energy Information Administration, Form EIA-63, "Annual Solar Thermal Collector and Photovoltaic Module Manufacturers Survey." 1985-1992-Energy Information Administration, Form CE-63A, "Annual Solar Thermal Collector Manufacturers Survey."

\section{Uses}

The largest end use for solar thermal collectors shipped in 1992 was for heating swimming pools, and it represented 88 percent of the total square feet shipped (Table 11). This application usually involved the use of low-temperature collectors. A common low-temperature pool-heating solar collector is a black plastic or rubberlike sheet with tubing through which water is circulated. The heat of the sun is directly transferred from the black absorbing material to the water circulating through the tubing to supply heat to the pool.

The second largest end use was for domestic hot water systems, which accounted for 11 percent of the total square feet shipped. Typical solar water-heating systems feature flat-plate collectors or collectors installed in an ICS or thermosiphon system. Unlike pool-heating systems, domestic solar water-heating systems nearly always have a conventional backup (i.e., gas or electric).

Additional medium-temperature collectors were shipped for space heating and cooling, and for installation into systems that provide both space and water heating. A small amount of high-temperature parabolic dish and trough collectors were shipped for electricity generation, research, and process heating in 1992.

\section{Markets}

In 1992, the largest market for solar thermal collectors was the residential market. Solar thermal collectors shipped to the residential sector in 1992 totaled 6.8 million square feet, 96 percent of total shipments (Table 12). This market sector primarily involves the use of low-temperature solar collectors for heating swimming pools and medium-temperature collectors for water heating in residential buildings. Collectors shipped to the residential sector increased 8 percent, compared with the corresponding 1991 level. The residential sector was also the largest market in 1991. The second largest market for solar thermal collectors in 1992 was the commercial sector, which accounted for 3 percent of total shipments.

\section{Destinations}

\section{Domestic}

Solar thermal collectors were shipped to 42 States, Puerto Rico, and the U.S. Virgin Islands in 1992. In 1991, 43 States, the District of Columbia, Puerto Rico, and the U.S. Virgin Islands received collector shipments. Eight states and the District of Columbia had no shipments in 1992. Four States (Alaska, Delaware, North Dakota, South Dakota, and Wyoming) did not receive solar thermal collector shipments in 1991 and 1992 (Table 13). The four States and one U.S. territory that received the largest amounts of solar thermal collectors in 1992, were: Florida (56 percent), California (26 percent), and Puerto Rico, Arizona, and Hawaii ( 3 percent each) (Table 14). All of the collectors manufactured in Puerto Rico remained on the island. The U.S. market for solar thermal collectors continued to be highly concentrated in a few States and Puerto Rico. Factors favorable for solar energy use that these States and Puerto Rico have in common are: (1) good solar insolation; (2) high electricity costs; (3) solarpromoting incentives, such as tax credits or exemptions; and (4) a demand for low technology solar pool heaters and solar domestic hot water systems. 
Table 10. Quantity, Value, and Average Price of Solar Thermal Collector Shlpments by Type, 1991 and 1992

\begin{tabular}{|c|c|c|c|c|c|c|}
\hline \multirow[b]{2}{*}{ Type } & \multicolumn{3}{|c|}{1992} & \multicolumn{3}{|c|}{1991} \\
\hline & $\begin{array}{l}\text { Quantity } \\
\text { (thousand } \\
\text { square feet) }\end{array}$ & $\begin{array}{l}\text { Value } \\
\text { (thousand } \\
\text { dollars) }\end{array}$ & $\begin{array}{l}\text { Average Price } \\
\text { (dollars per } \\
\text { square foot) }\end{array}$ & $\begin{array}{l}\text { Quantity } \\
\text { (thousand } \\
\text { square feet) }\end{array}$ & $\begin{array}{l}\text { Value } \\
\text { (thousand } \\
\text { dollars) }\end{array}$ & $\begin{array}{l}\text { Average Price } \\
\text { (dollars per } \\
\text { square foot) }\end{array}$ \\
\hline $\begin{array}{l}\text { Low-Temperature } \\
\text { Liquid and Air . . . . . . . . . }\end{array}$ & 6,187 & 15,403 & 2.49 & 5,585 & 16,206 & 2.90 \\
\hline $\begin{array}{l}\text { Medlum-Temperature } \\
\text { Air } \ldots \ldots \ldots \ldots \ldots \ldots \ldots \ldots \\
\text { Liquid }\end{array}$ & 1 & 8 & 11.57 & W & W & W \\
\hline $\begin{array}{l}\text { ICS/Thermosiphon } \ldots \ldots \ldots \\
\text { Flat Plate . . . . . . . . . . . } \\
\text { Evacuated Tube . . . . . . . } \\
\text { Concentrator . . . . . . . . } \\
\text { All Medium Temperature . . . }\end{array}$ & $\begin{array}{r}303 \\
584 \\
W \\
W \\
897\end{array}$ & $\begin{array}{r}3,825 \\
5,441 \\
W \\
W \\
9,831\end{array}$ & $\begin{array}{l}12.64 \\
9.32 \\
W \\
W \\
10.96\end{array}$ & $\begin{array}{r}260 \\
703 \\
W \\
1 \\
989\end{array}$ & $\begin{array}{r}4,965 \\
6,375 \\
W \\
275 \\
11,807\end{array}$ & $\begin{array}{c}19.08 \\
9.07 \\
W \\
218.79 \\
11.94\end{array}$ \\
\hline $\begin{array}{l}\text { High-Temperature } \\
\text { Parabolic Dish and Trough ... }\end{array}$ & 2 & 148 & 75.66 & 1 & 23 & 31.94 \\
\hline Total $\ldots \ldots \ldots \ldots \ldots \ldots$ & 7,086 & 25,382 & $\cdots$ & 6,574 & 28,036 & -- \\
\hline
\end{tabular}

$W=$ Data withheld to avoid disclosure. ICS = Integral collector storage. $\cdots=$ Not applicable.

Note: Totals may not equal sum of components due to independent rounding.

Source: Energy Information Administration, Form CE-63A, "Annual Solar Thermal Collector Manufacturers Survey."

Figure 3. Average Price of Solar Thermal Collectors, 1991 and 1992

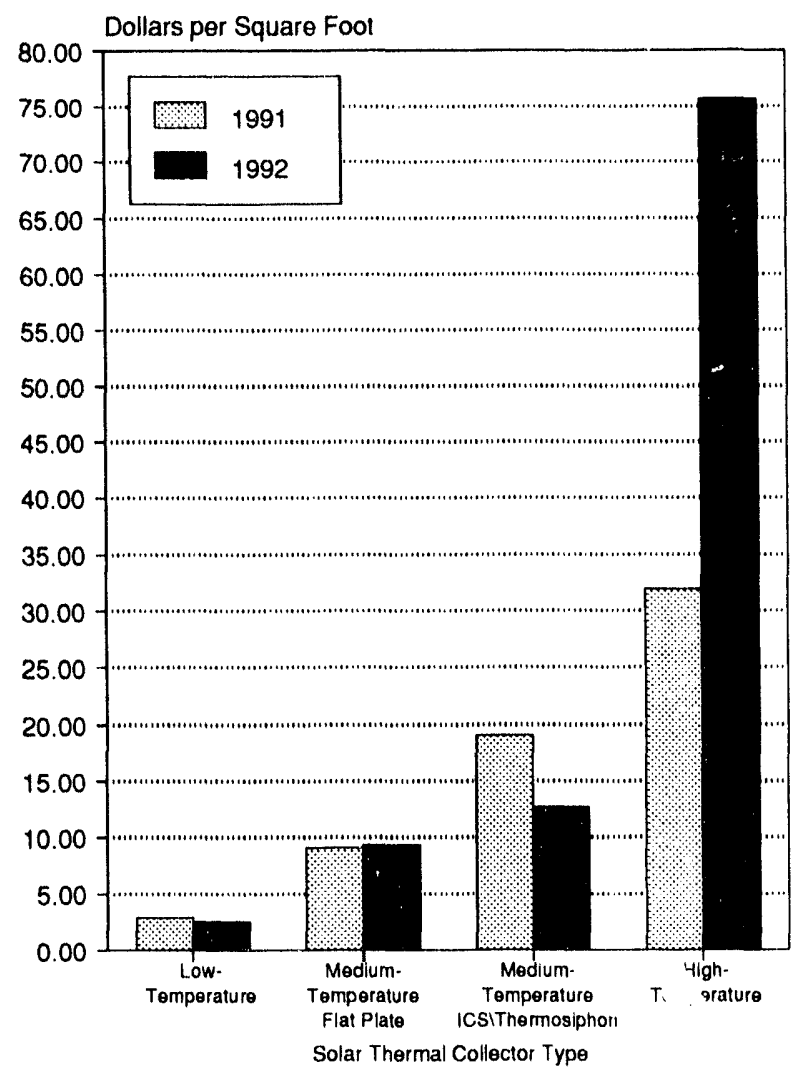

Source: Energy Information Administration, Form CE-63A, "Annual Solar Thermal Collector Manufacturers Survey."

\section{Export}

Exports accounted for 4 percent of total shipments in 1992. Sixteen companies exported solar thermal collectors compared with 13 companies in 1991. Of total 1992 exports, low-temperature collectors accounted for 20 percent and medium-temperature collectors 80 percent. Summed by continents, the largest percentage of shipments were to North America (51 percent), followed by Asia (31 percent) and Europe (14 percent) (Table 15). Trading countries that received export shipments were Taiwan (25 percent), Mexico (10 percent), Canada (6 percent), the Bahamas ( 6 percent), and Guatemala (5 percent) (Table 16).

\section{Systems}

Of the 45 companies reporting shipments of solar thermal collectors in 1992, 35 reported shipments of 15,946 complete solar thermal collector systems. This was an 8 percent increase compared with 1991 (Table 17). A complete system is a unit with a collector and all the necessary functional components, except for installation materials. Included are thermosiphon systems, integral collector storage systems, packaged systems, and system kits. The 15,946 complete systems accounted for 2.8 million square feet of collectors, an increase of 24 percent in square feet shipped, compared with 1991. The total value for the systems shipped in 1992 was $\$ 19.4$ million, compared with $\$ 19.5$ million in 1991 . 
Table 11. Shipments of Solar Thermal Colleciors by End Use and Type, 1991 and 1992 (Thousand Square Feet)

\begin{tabular}{|c|c|c|c|c|c|c|c|c|c|}
\hline \multirow[b]{3}{*}{ End Use } & \multirow{2}{*}{$\begin{array}{c}\begin{array}{c}\text { Low- } \\
\text { Temperature }\end{array} \\
\text { Liquid/Air }\end{array}$} & \multicolumn{5}{|c|}{ Medlum-Temperature } & \multirow{3}{*}{$\begin{array}{c}\text { High- } \\
\text { Temperature } \\
\\
\text { Parabolic } \\
\text { Dish } / \text { Trough } \\
\end{array}$} & \multirow[b]{3}{*}{$\begin{array}{l}1992 \\
\text { Total }\end{array}$} & \multirow[b]{3}{*}{$\begin{array}{l}1991 \\
\text { Total }\end{array}$} \\
\hline & & \multirow[b]{2}{*}{ Air } & \multicolumn{4}{|c|}{ Liquid } & & & \\
\hline & $\begin{array}{l}\text { Metallic and } \\
\text { Nonmetallic }\end{array}$ & & $\begin{array}{c}\text { ICS/ } \\
\text { Thermo- } \\
\text { siphon }\end{array}$ & $\begin{array}{l}\text { Flat-Plate } \\
\text { (Pumped) }\end{array}$ & $\begin{array}{c}\text { Evacu- } \\
\text { ated } \\
\text { Tube }\end{array}$ & $\begin{array}{c}\text { Concen- } \\
\text { trator }\end{array}$ & & & \\
\hline Pool Heating $\ldots .$. & 6,177 & 0 & 0 & 34 & 0 & 0 & 0 & 6,210 & 5,535 \\
\hline Hot Water & 0 & (s) & 276 & 516 & $w$ & $w$ & 0 & 801 & 989 \\
\hline Space Heating & 10 & (s) & 25 & 0 & (s) & 0 & 0 & 35 & 24 \\
\hline Space Cooling ..... . & 0 & 0 & 0 & 0 & $w$ & $w$ & 1 & 1 & 2 \\
\hline \multicolumn{10}{|l|}{ Combined Space and } \\
\hline Water Heating & 0 & 0 & 0 & 4 & (s) & 0 & 0 & 5 & a \\
\hline Process Heating $\ldots \ldots \ldots \ldots$ & 0 & 0 & 2 & 29 & 0 & 0 & (s) & 32 & 12 \\
\hline Electricity Generation . . . . . . & 0 & 0 & 0 & (s) & 0 & 0 & (s) & 1 & 1 \\
\hline Other & 0 & 0 & 0 & 0 & 0 & 0 & 1 & 1 & 1 \\
\hline Total $\ldots \ldots \ldots \ldots \ldots$ & 6,187 & 1 & 303 & 584 & $w$ & $w$ & 2 & 7,086 & 6,574 \\
\hline
\end{tabular}

(s) = Less than 500 square feet. ICS = Integral Collector Storage. $W=$ Data withheld to avoid disclosure.

Note: Totals may not equal sum of components due to independent rounding.

Source: Energy Information Administration, Form CE-63A, "Annual Solar Thermal Collector Manufacturers Survey."

Table 12. Shipments of Solar Thermal Collectors by Market and Type, 1991 and 1992 (Thousand Square Feet)

\begin{tabular}{|c|c|c|c|c|c|c|c|c|c|}
\hline \multirow[b]{3}{*}{ Market Sector } & \multirow{3}{*}{$\begin{array}{c}\text { Low- } \\
\text { Temperature } \\
\text { Liquid/Air } \\
\text { Metallic and } \\
\text { Nonmetallic }\end{array}$} & \multicolumn{5}{|c|}{ Medium-Temperature } & \multirow{3}{*}{$\begin{array}{c}\text { High- } \\
\text { Temperature } \\
\\
\text { Parabolic } \\
\text { Dish/Trough }\end{array}$} & \multirow[b]{3}{*}{$\begin{array}{l}1992 \\
\text { Total }\end{array}$} & \multirow[b]{3}{*}{$\begin{array}{l}1991 \\
\text { Total }\end{array}$} \\
\hline & & \multirow[b]{2}{*}{ Air } & \multicolumn{4}{|c|}{ Liquid } & & & \\
\hline & & & $\begin{array}{l}\text { ICS/ } \\
\text { Thermo- } \\
\text { siphon }\end{array}$ & $\begin{array}{l}\text { Flat-Plate } \\
\text { (Pumped) }\end{array}$ & $\begin{array}{c}\text { Evacu- } \\
\text { ated } \\
\text { Tube }\end{array}$ & $\begin{array}{l}\text { Concen- } \\
\text { trator }\end{array}$ & & & \\
\hline Residential & 6,018 & 1 & 295 & 508 & $w$ & $w$ & 0 & 6,832 & 6,322 \\
\hline Commercial & 158 & 0 & 4 & 41 & $w$ & W & 0 & 204 & 225 \\
\hline Industrial & 10 & 0 & 2 & 16 & 0 & 0 & 0 & 27 & 13 \\
\hline Utility & 0 & 0 & 2 & 16 & 0 & 0 & 0 & 17 & 12 \\
\hline Other & 0 & 0 & (s) & 3 & 0 & 0 & 2 & 6 & 2 \\
\hline Total ..... & 6,187 & 1 & 303 & 584 & $w$ & $w$ & 2 & 7,086 & 6,574 \\
\hline
\end{tabular}

$(s)=$ Less than 500 square feet. ICS $=$ Integral Collector Storage.

$W=$ Data withheld to avoid disclosure.

Note: Totals may not equal sum of components due to independent rounding

Source: Energy Information Administration, Form CE-63A, "Annual Solar Thermal Collector Manufacturers Survey." 
Table 13. Shlpments of Solar Thermal Collectors by Destination, 1991 and 1992 (Square Feet)

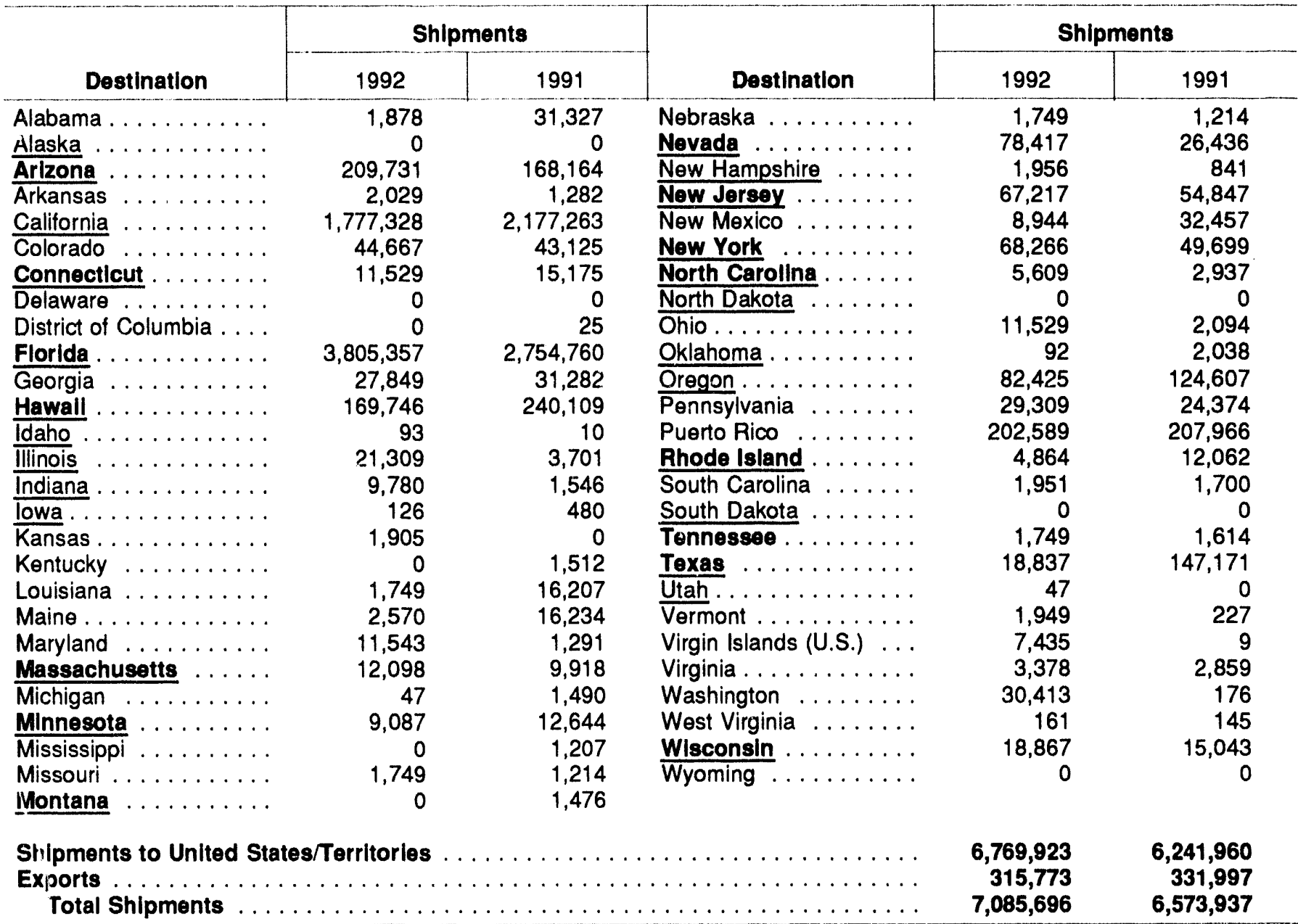

INotes: States shown in bold print sponsored incentives for solar thermal collector purchases during 1991 (Solar Energy Industries Association, Solar Industry Journal, First Quarter 1992, pp. 16-21). Underlined States sponsored incentives during 1992 (Solar Energy Industries Association, Solar Industry Journal, First Quarter 1993, pp. 21-28).

Source: Energy Information Administration, Form CE-63A, "Annual Solar Thermal Collector Manufacturers Survey."

Table 14. The Top Flve Destinations of Shlpments, 1991 and 1992

\begin{tabular}{|c|c|c|c|c|c|c|}
\hline \multirow[b]{2}{*}{ State or Territory } & \multicolumn{3}{|c|}{1992 Shipments } & \multicolumn{3}{|c|}{1991 Shipments } \\
\hline & $\begin{array}{l}\text { Thousand } \\
\text { Square Feet }\end{array}$ & $\begin{array}{l}\text { Percent of } \\
\text { U.S. Total }\end{array}$ & Rank & $\begin{array}{l}\text { Thousand } \\
\text { Square Feet }\end{array}$ & $\begin{array}{l}\text { Percent of } \\
\text { U.S. Total }\end{array}$ & Rank \\
\hline Florida & 3,805 & 56 & 1 & 2,755 & 44 & 1 \\
\hline California & 1,777 & 26 & 2 & 2,177 & 35 & 2 \\
\hline Arizona & 210 & 3 & 3 & 168 & 3 & 5 \\
\hline Puerto Rico & 203 & 3 & 4 & 208 & 3 & 4 \\
\hline Hawaii $\ldots \ldots \ldots \ldots \ldots$ & 170 & 3 & 5 & 240 & 4 & 3 \\
\hline Top Five Total & 6,165 & 91 & & 5,548 & 89 & \\
\hline
\end{tabular}

Note: Totals may not equal sum of components due to independent rounding.

Source: Energy Information Administration, Form CE-63A, "Annual Solar Thermal Collector Manufacturers Survey." 
Table 15. Distribution of Solar Thermal Collector Exports by Continent, 1992 (Percent of Total Exports)

\begin{tabular}{|c|c|}
\hline Continent & Percent of Exports \\
\hline 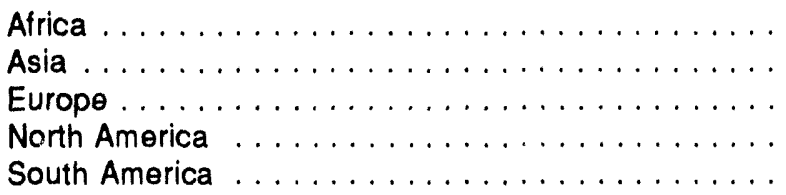 & $\begin{array}{r}3.2 \\
30.8 \\
14.2 \\
50.6 \\
1.3\end{array}$ \\
\hline Total & 100.0 \\
\hline
\end{tabular}

Note: Totals may not equal sum of components due to independent rounding.

Source: Prepared by staff of the Survey Management Division, Office of Coal, Nuclear, Electric and Alternate Fuels, Energy Information Administration, based on data submitted on Energy Information Administration, Form CE-63A, "Annual Solar Thermal Collector Manufacturers Survey."

Table 16. Distribution of Solar Thermal Collector Exports by Country Within Continent, 1992

\begin{tabular}{|c|c|c|}
\hline Continent & Country & $\begin{array}{l}\text { Percent } \\
\text { of Exports }\end{array}$ \\
\hline $\begin{array}{l}\text { Africa } \ldots \ldots \ldots \ldots \ldots \ldots \ldots \ldots \\
\text { Asia } \ldots \ldots \ldots \ldots \ldots \ldots \ldots\end{array}$ & $\begin{array}{l}\text { Egypt } \\
\text { Saudi Arabia } \\
\text { Taiwan } \\
\text { Other Asia/Pacific Rim }\end{array}$ & $\begin{array}{r}3.2 \\
2.0 \\
25.0 \\
3.7\end{array}$ \\
\hline$\ldots \ldots \ldots \ldots \ldots$ & England & 4.0 \\
\hline North America & $\begin{array}{l}\text { Germany } \\
\text { Other Europe } \\
\text { Bahamas }\end{array}$ & $\begin{array}{l}4.2 \\
5.9 \\
5.8\end{array}$ \\
\hline South America $\ldots \ldots \ldots \ldots \ldots$ & $\begin{array}{l}\text { Canada } \\
\text { Costa Rica } \\
\text { Guatemala } \\
\text { Mexico } \\
\text { Other Caribbean/Central America } \\
\text { Ecuador } \\
\text { Other South America }\end{array}$ & $\begin{array}{r}6.4 \\
4.0 \\
4.5 \\
9.5 \\
20.3 \\
0.6 \\
0.6\end{array}$ \\
\hline Total & & 100.0 \\
\hline
\end{tabular}

Notes: Other represents shipments to countries not disaggregated by companies on Form CE-63A and may include shipments to enumerated countries. Totals may not equal sum of components due to independent rounding.

Source: Energy Information Administration, Form CE-63A, "Annual Solar Thermal Collector Manufacturers Survey."

Table 17. Complete Solar Thermal Collector Systems Shlpped, 1990-1992

\begin{tabular}{|c|c|c|c|}
\hline & 1992 & 1991 & 1990 \\
\hline 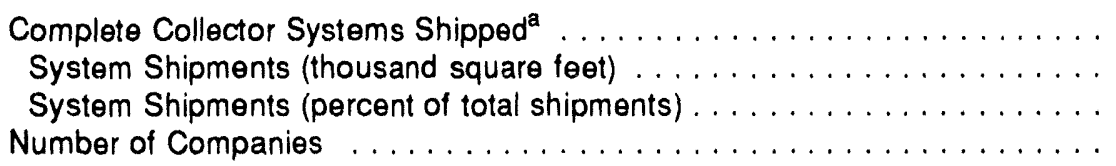 & $\begin{array}{r}15,946 \\
2,763 \\
39 \\
35\end{array}$ & $\begin{array}{r}14,780 \\
2,220 \\
34 \\
34\end{array}$ & $\begin{array}{r}12,131 \\
6,561 \\
58 \\
31\end{array}$ \\
\hline Value of Systems (thousand dollars) & 19,390 & 19,451 & 25,834 \\
\hline
\end{tabular}

${ }^{a} A$ complete system is a unit with a collector and all the necessary functional components, except for installation materials. Source: 1990-1992-Energy Information Administration, Form CE-63A, "Annual Solar Thermal Collector Manufacturers Survey." 


\section{Photovoltaic Cell and Module Manufacturing Activities}

This chapter presents information on the U.S. photovoltaic cell and module manufacturing industry in 1992. It covers the status of the industry, photovoltaic cell and module shipments (expressed in peak watts), manufacturing origins, destinations, imports, exports, cell and module types, values and prices, and uses and markets. Photovoltaic shipments data in this chapter include both cells and modules manufactured by U.S. companies that were shipped for domestic use and for export and also imported cells and modules.

A photovoltaic module is an integrated array of photovoltaic cells assembled into a panel. Photovoltaic cells are the unencapsulated semiconductor components of the module. The photovoltaic cells convert solar energy to electricity. Cells and modules manufactured and shipped for space and satellite applications are not included in this report.

\section{Industry Status}

Photovoltaic cell and module shipments totaled 15.6 peak megawatts in 1992 (Table 18). These shipments were reported by 21 companies. Seven companies expect to introduce new crystalline-silicon module products, and ten companies reported plans to introduce new thin-film products to the industry during 1993. Two companies reported plans to produce new photovoltaic concentrator products and four plan new non-module system components during 1993 (Table 19).

Employment in photovoltaic-related activities totaled 1,463 person-years in 1992 (Table 20), a decrease of 125 person-years from the 1991 level of employment. The average employment per company was 70 person-year 3 in 1992, compared with 69 person-years in 1991. Of the 21 companies that reported shipments in 1992, 43 percent reported employment levels of more than 10 person-years each.

Table 18. Photovoltaic Cell and Module Companies and Shipments, 1982-1992

(Peak Kilowatts)

\begin{tabular}{|c|c|c|c|c|}
\hline \multirow[b]{2}{*}{ Year } & \multirow{2}{*}{$\begin{array}{l}\text { Number of } \\
\text { Companies }\end{array}$} & \multicolumn{3}{|c|}{ Photovoltalc Cells and Modules } \\
\hline & & Total Shipments & Import Shipments & Export Shipments \\
\hline $1992^{\mathrm{a}}$ & 21 & 15,583 & 1,602 & 9,823 \\
\hline $1991^{\mathrm{a}}$ & 23 & 14,939 & 2,059 & 8,905 \\
\hline$\ldots \ldots$ & ${ }^{b} 19$ & ${ }^{b} 13,837$ & 1,398 & 7,544 \\
\hline$\ldots \ldots$ & 17 & 12,825 & 826 & 7,363 \\
\hline $1988^{a}$ & 14 & 9,676 & $i, 453$ & 5,358 \\
\hline $1987^{a}$ & 17 & 6,850 & 921 & 3,821 \\
\hline$\ldots \ldots$ & 17 & 6,333 & 678 & 3,109 \\
\hline $1985^{a}$ & 15 & 5,769 & 285 & 1,670 \\
\hline 1984 & 23 & 9,912 & NA & 2,153 \\
\hline$\ldots \ldots$ & 18 & 12,620 & NA & 1,903 \\
\hline $1982 \ldots \ldots \ldots$ & 19 & 6,897 & NA & NA \\
\hline
\end{tabular}

${ }^{a}$ Does not include shipments of cells and modules for space/satellite applications.

Includes imputed data for one nonrespondent, which exited the industry during 1990. See Appendix A for imputation method.

NA $=$ Not available.

Note: Total shipments include import and export shipments.

Sources: 1982-1984-Energy Information Administration, Form ElA-63, "Annual Solar Thermal Collector and Photovoltaic Module Manufacturers Survey." 1985-1992-Energy Information Administration, Form CE-63B, "Annual Photovoltaic Module/Cell Manufacturers Survey." 
Table 19. Companles Expecting to Introduce New Photovoltalc Products in 1993

\begin{tabular}{|c|c|c|}
\hline \multicolumn{2}{|c|}{ Now Product Typo } & $\begin{array}{l}\text { Number of } \\
\text { Companles }\end{array}$ \\
\hline \multicolumn{2}{|c|}{$\begin{array}{l}\text { Crystalline Sllicon } \\
\text { Single-Crystal Silicon Modules } \ldots \ldots \ldots \\
\text { Cast Silicon Modules } \ldots \ldots \ldots \ldots \ldots \\
\text { Ribbon Silicon Modules } \ldots \ldots \ldots \ldots \ldots\end{array}$} & $\begin{array}{l}3 \\
3 \\
1\end{array}$ \\
\hline \multicolumn{2}{|c|}{$\begin{array}{l}\text { Thin-Film } \\
\text { Amorphous Silicon Modules } \ldots \ldots \ldots \\
\text { Other } \ldots \ldots \ldots \ldots \ldots \ldots \ldots \ldots\end{array}$} & $\begin{array}{l}6 \\
4\end{array}$ \\
\hline \multicolumn{2}{|c|}{$\begin{array}{l}\text { Concentrators } \ldots \ldots \ldots \ldots \ldots \ldots \ldots \\
\text { Non Module System Components } \ldots \ldots\end{array}$} & $\begin{array}{l}2 \\
4\end{array}$ \\
\hline \multirow{2}{*}{\multicolumn{3}{|c|}{$\begin{array}{l}\text { Source: Energy Information Administration, } \\
\text { CE-63B, "Annual Photovoltaic Module/Cell Manufac } \\
\text { Survey." } \\
\text { Table 20. Employment In the Photovoltalc } \\
\text { Manufacturing Industry, 1989-1992 }\end{array}$}} \\
\hline & & \\
\hline Year & $\begin{array}{l}\text { Number of } \\
\text { Companles }\end{array}$ & $\begin{array}{l}\text { Number of } \\
\text { Person-Years }\end{array}$ \\
\hline $\begin{array}{l}1992 \ldots \ldots \ldots \ldots \\
1991 \ldots \ldots \ldots \ldots \\
1990 \ldots \ldots \ldots \ldots \\
1989 \ldots \ldots \ldots \ldots\end{array}$ & $\begin{array}{l}21 \\
23 \\
19 \\
17\end{array}$ & $\begin{array}{l}1,463 \\
1,588 \\
1,622 \\
1,645\end{array}$ \\
\hline
\end{tabular}

Source: Energy Information Administration, Form CE-63B, "Annual Photovoltaic Module/Cell Manufacturers Survey."

Of the 21 companies that reporied in 1992, most were engaged in a broad range of photovoltaic-related activities other than manufacturing and/or importing cells or modules. Eighteen of the 21 companies were involved in module or system design, 15 were active in development of module prototypes, and 12 were active in development of photovoltaic system prototypes (Table 21). Fourteen companies were wholesalers, and 9 companies were retailers. Seven companies, five less than in 1991, were installers of photovoltaic cells or modules.

\section{Shipments}

Photovoltaic cell and module shipments in 1992 totaled 15.6 peak megawatts, an increase of 4 percent from the 1991 level (Table 18). Module shipments totaled 12.8 peak megawatts and cell shipments totaled 2.8 peak megawatts. Total shipments have increased 170 percent since 1985 (Figure 4). Beginning in 1985, data for
Table 21. Number of Companles Involved in Photovoltalc Related Activities, 1991 and 1992

\begin{tabular}{|c|c|c|}
\hline \multirow[b]{2}{*}{ Type of Activity } & \multicolumn{2}{|c|}{$\begin{array}{l}\text { Number of } \\
\text { Companles }\end{array}$} \\
\hline & 1992 & 1991 \\
\hline Cell Manufacturing & 13 & 11 \\
\hline Module or System Design & 18 & 19 \\
\hline Prototype Module Development & 15 & 16 \\
\hline Prototype Systems Development . . & 12 & 14 \\
\hline Wholesale Distribution & 14 & 15 \\
\hline Retail Distribution ... & 9 & 12 \\
\hline Installation $\ldots \ldots \ldots \ldots$ & 7 & 12 \\
\hline $\begin{array}{l}\text { Non-Collector System } \\
\text { Component Manufacture }\end{array}$ & 6 & 9 \\
\hline
\end{tabular}

Source: Energy Information, Form CE-63B, "Annual Photovoltaic Module/Cell Manufacturers Survey."

Figure 4. Photovoltaic Cell and Module Shipments, 1985-1992

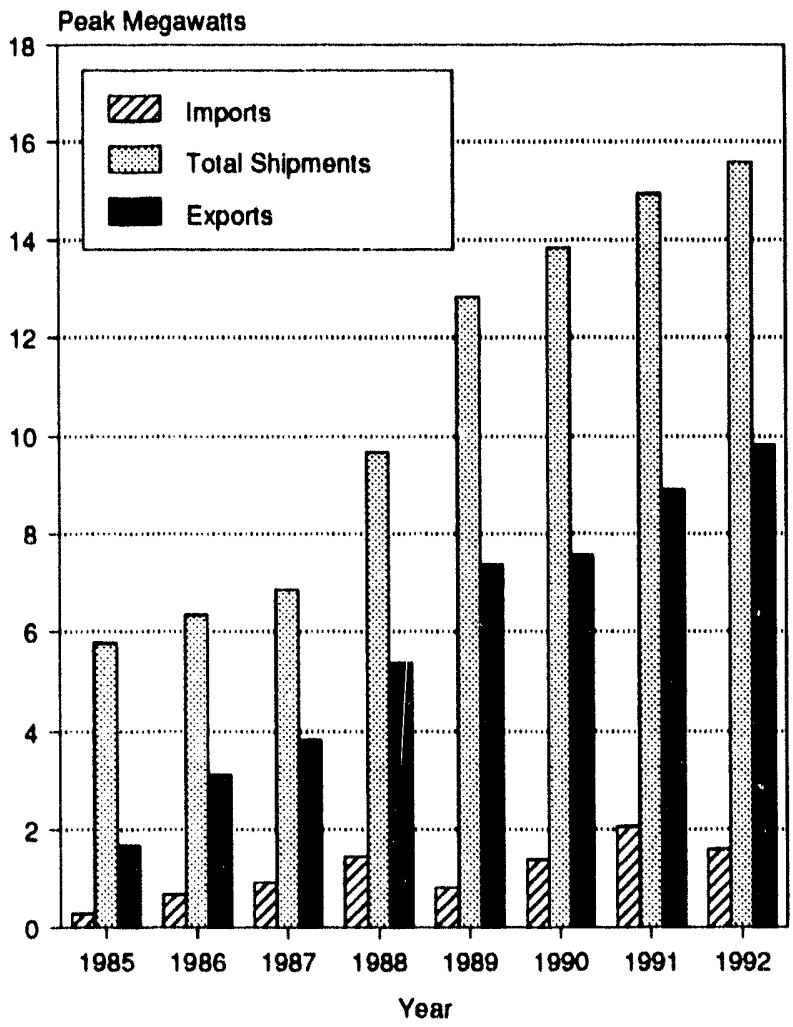

Source: Energy Information Administration, Form CE-63B, "Annual Photovoltaic Module/Cell Manufacturers Survey." 
photovoltaic cells and modules for terrestrial use (not space applications) were first reported.

\section{Imports}

Import shipments of photovoltaic cell and modules in 1992 totaled 1.6 peak megawatts, or 10 percent of total shipments (Table 18). These shipments were reported by seven companies. The predominant type of photovoltaic import was crystalline silicon. The countries of origin for the imports were Australia, China, Japan, and the United Kingdom. Japan accounted for most of the imported photovoltaic cells and modules.

\section{Distribution}

In 1992, photovoltaic cell and module shipments totaling 8.6 peak megawatts (55 percent of total shipments) were sent directly to wholesale dist ibutors (Table 22). Installers and end users received 2.2 peak megawatts (14 percent of total shipments). Photovoltaic cell manufacturers shipped 2.5 peak megawatts to the companies that manufacture (assemble) cells into photovoltaic modules. Under "Other," 1.1 peak megawatts of cells and modules were shipped predominantly to original equipment manufacturers (OEM) in 1992.

Table 22. Distribution of Photovoltaic Cells and Modules, 1991 and 1992

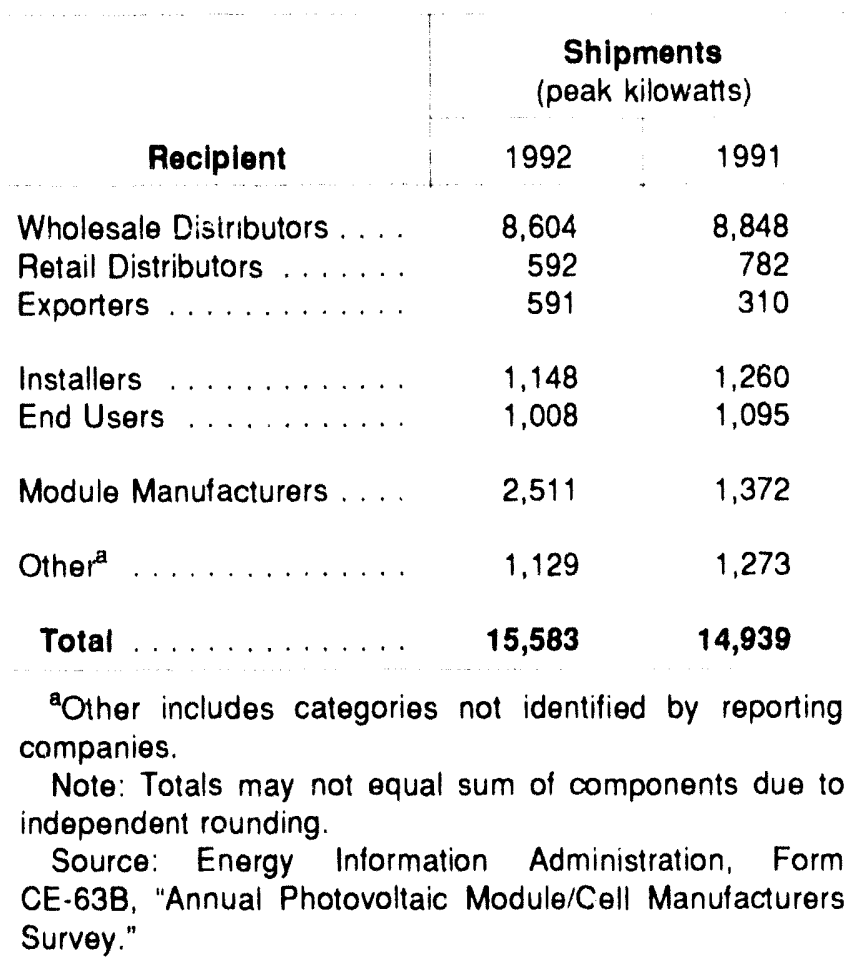

\section{Cell and Module Types}

Photovoltaic shipments are divided into three categories by product type: (1) crystalline silicon cells and modules (includes single-crystal, cast silicon, and ribbon silicon); (2) thin-film cells and modules (made from a number of layers of photosensitive materials such as amorphous silicon); (3) concentrator cells and modules (in which a lens is used to gather and focus a larger area of sunlight onto a smaller area of the cell or module).

Crystalline silicon cells and modules continued to dominate the photovoltaic industry, accounting for 93 percent of total shipments in 1992 (Table 23). In particular, single-crystal silicon shipments totaled 9.1 peak megawatts, an increase of 5 percent compared with corresponding 1991 shipments (Figure 5). Together, cast and ribbon silicon shipments totaled 5.4 peak megawatts, a 3 percent decrease from the corresponding 1991 shipments.

From 1991 to 1992, thin-film shipments increased 49 percent, while from 1990 to 1991, shipments fell 45 percent. The overall trend from 1990 to 1992 was, however, a decline of 19 percent. Thin-film shipments represented 7 percent of total shipments in 1992.

\section{Values and Prices}

The total value of photovoltaic cell and module shipments was $\$ 87.1$ million in 1992, a slight increase over the 1991 value of $\$ 86.7$ million (Table 24). The total value includes charges for advertising and warranties but does not include excise taxes or the cost of freight or transportation for the shipments.

The total value of crystalline silicon (single-crystal, cast, and ribbon) shipments was $\$ 80$ million in 1992, a 2percent decrease compared with the corresponding 1991 value. The value of thin-film shipments in 1992 was $\$ 6.9$ million, 49 percent higher than the corresponding 1991 level.

The average price of crystalline silicon modules in 1992 was $\$ 6.10$ per peak watt, a small decrease from the price in 1991 (Figure 6). The average price for thin-film modules was $\$ 6.31$ per peak watt, 1 percent higher than their 1991 price. For concentrator modules, the average price was $\$ 4.37$ per peak watt, 68 percent lower than their 1991 price (Table 24). This decrease is due to increased levels of shipping by a small number of companies and concurrent lower unit costs. 
Table 23. Photovoltalc Cell and Module Shlpments by Type, 1990-1992

\begin{tabular}{|c|c|c|c|c|c|c|}
\hline \multirow[b]{2}{*}{ Type } & \multicolumn{3}{|c|}{ Shlpments (peak kilowatts) } & \multicolumn{3}{|c|}{ Percent of Total Shipments } \\
\hline & 1992 & 1991 & 1990 & 1992 & 1991 & 1990 \\
\hline $\begin{array}{l}\text { Crystalline Silicon } \\
\text { Single-Crystal } \ldots \ldots \ldots \ldots \ldots \\
\text { Cast and Ribbon } \ldots \ldots \ldots \ldots \ldots \\
\quad \text { Subtotal } \ldots \ldots \ldots \ldots \ldots \ldots\end{array}$ & $\begin{array}{r}9,078 \\
5,379 \\
14,457\end{array}$ & $\begin{array}{r}8,685 \\
5,520 \\
14,205\end{array}$ & $\begin{array}{r}7,486 \\
5,006 \\
12,492\end{array}$ & $\begin{array}{l}58 \\
35 \\
93\end{array}$ & $\begin{array}{l}58 \\
37 \\
95\end{array}$ & $\begin{array}{l}54 \\
36 \\
90\end{array}$ \\
\hline Thin-Film Silicon ....... & 1,075 & 723 & 1,321 & 7 & 5 & 10 \\
\hline Concentrator Silicon & 40 & 12 & 24 & $(")$ & $(*)$ & $(*)$ \\
\hline Other $\ldots \ldots \ldots \ldots \ldots \ldots$ & 11 & 0 & 0 & $(*)$ & 0 & 0 \\
\hline Total & 15,583 & 14,939 & 13,837 & 100 & 100 & 100 \\
\hline
\end{tabular}

*Represents less than 0.5 , rounded to zero.

Notes: Data do not include shipments of cells and modules for space/satellite applications. Totals may not equal sum of components due to independent rounding.

Source: Energy Information Administration, Form CE-63B, "Annual Photovoltaic Module/Cell Manufacturers Survey."

Figure 5. Photovoltaic Cell and Module Shipments by Type, 1989-1992

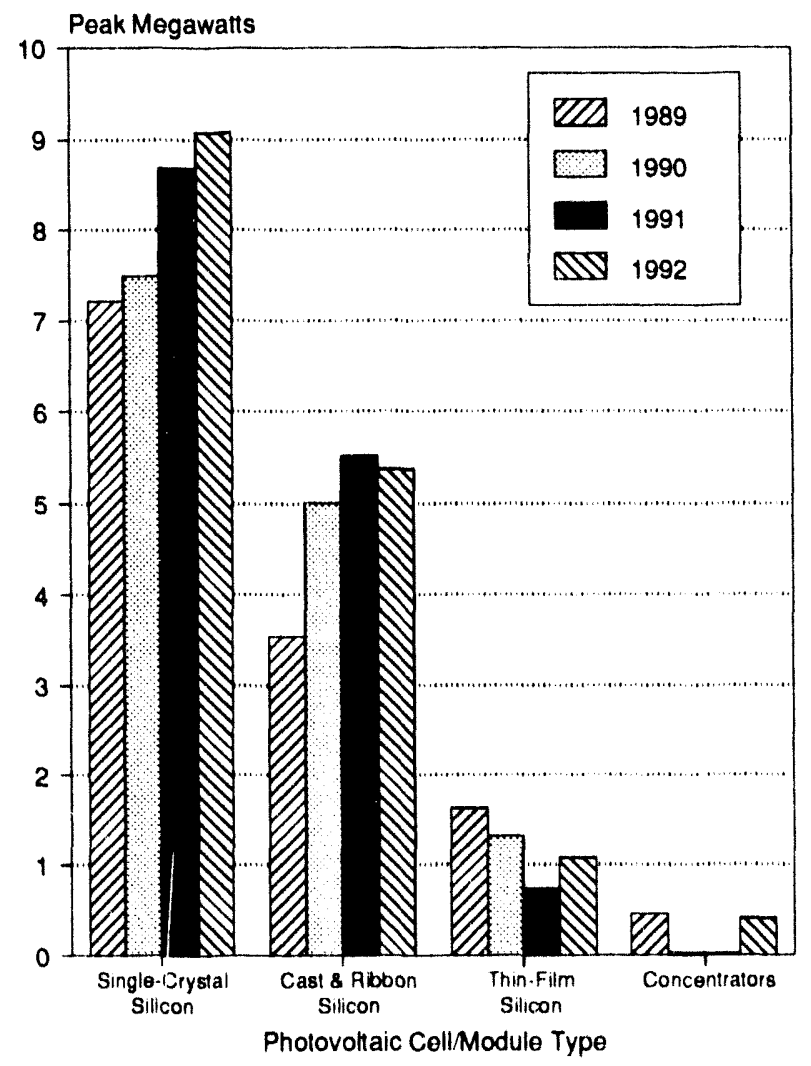

Source: Energy Information Administration, Form CE-63B, "Annual Photovoltaic Module/Cell Manufacturers Survey."

\section{Uses}

The largest application by end use for photovoltaic cells and modules in 1992 was for electricity generation (combined grid-interactive and remote). This represented 35 percent of total shipments (Table 25). Eightynine percent of the 5.5 peak megawatts represented by this end use involved crystalline silicon cells and modules. Grid interactive and remote, or stand alone, power generation for general uses include those for grid distribution and general remote uses for residential power and power for mobile homes.

The second largest photovoltaic end use was to power fixed-base communications equipment, such as mountain-top, signal repeater stations. Cells and modules for communications accounted for 3.7 peak megawatts in 1992, 24 percent of total shipments. In 1991, communications was also the second largest photovoltaic end-use application, representing 24 percent of total shipments.

Photovoltaic units to power consumer goods, such as portable computers and radios, toys, watches, and small battery chargers, totalled 2.6 peak megawatts, the third largest application in 1992. End uses related to transportation and water pumping accounted for 1.6 peak megawatts and 0.8 peak megawatts, respectively, in 1992 and involved primarily the use of crystalline silicon cells and modules. Photovoltaic cells and modules for transportation include cells and modules on boats, cars, and recreational vehicles, and those used 
Table 24. Value and Average Price of Cells and Modules by Type, 1991 and 1992

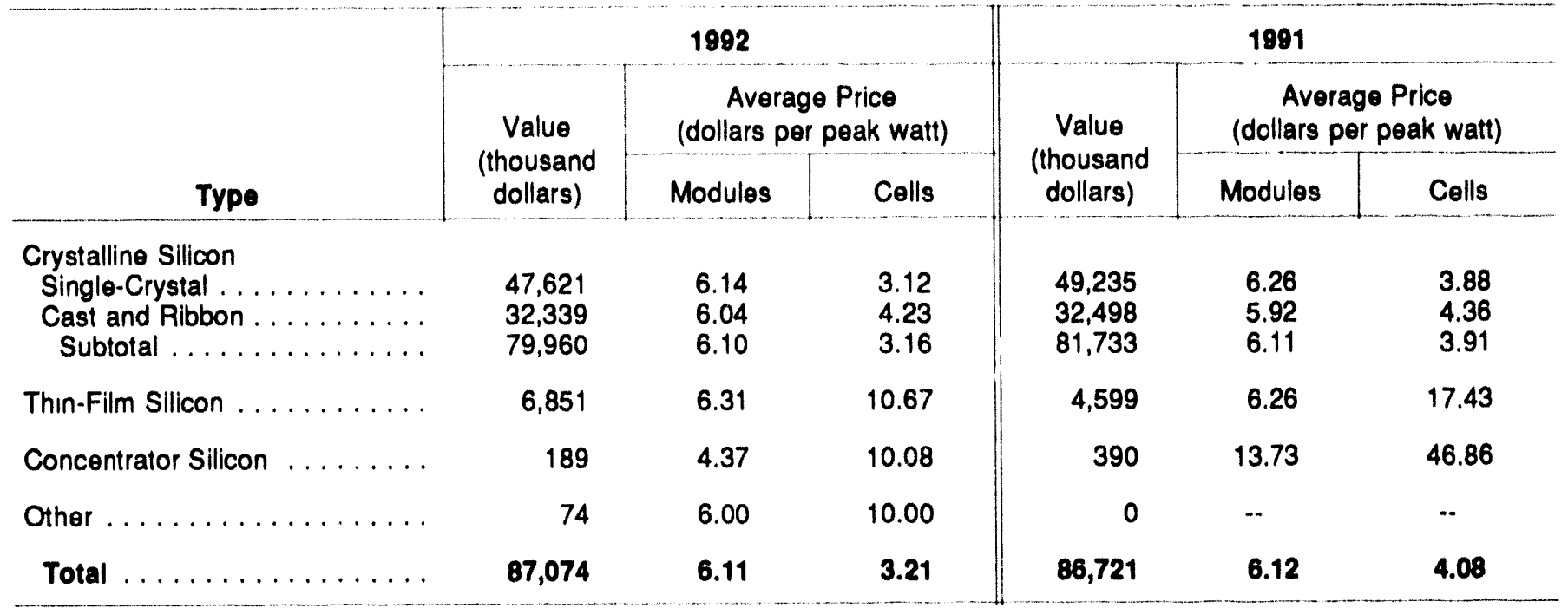

$W=$ Data withheld to avoid disclosure.

-. = Not Applicable.

Notes: Data do not include shipments of cells and modules for space/satellite applications. Totals may not equal sum of components due to independent rounding.

Source: Energy Information Administration, Form CE-63B, "Annual Photovoltaic Module/Cell Manufacturers Survey."

Figure 6. Average Price of Photovoltalc Modules, 1990-1992

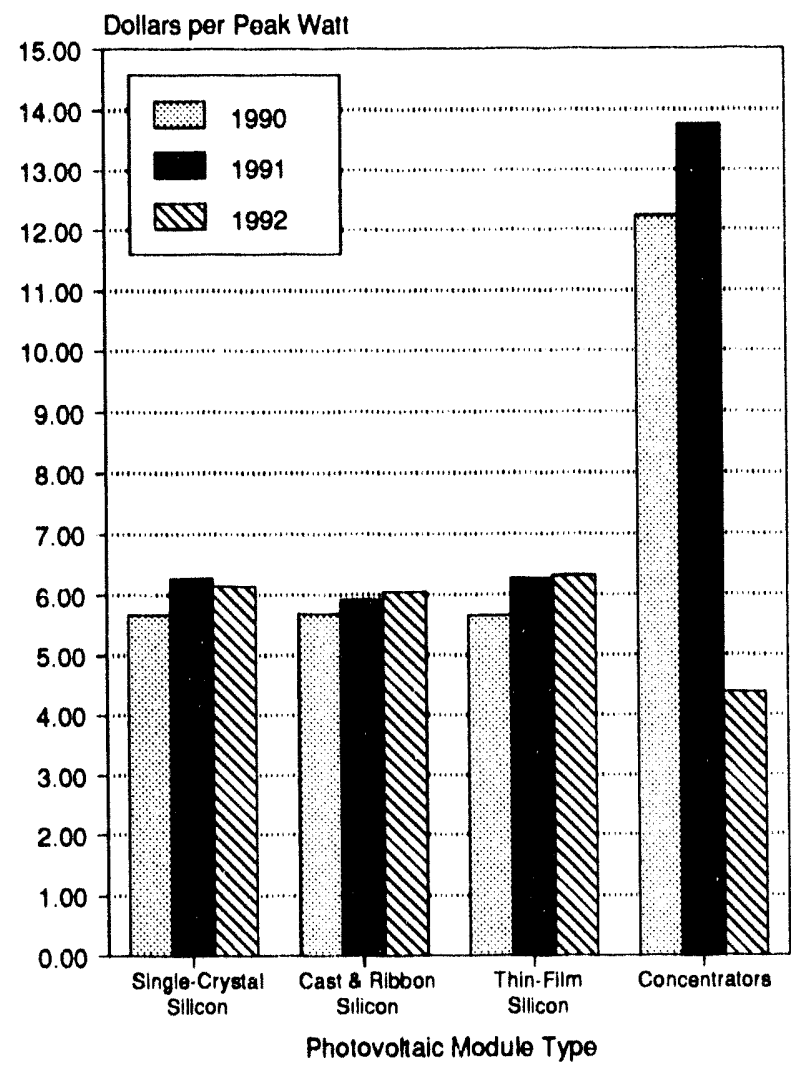

Source: Energy Information Administration, Form CE-63B, "Annual Photovoltaic Module/Cell Manufacturers Survey." for transportation support systems such as signs, illumination, and warning signals.

Original equipment manufacturers accounted for 0.8 peak megawatts in 1992 and 1.3 peak megawatts in 1991. Ihotovoltaic cells and modules used for health and medical purposes, such as those used for powering refrigerators, medical equipment, and water purifiers, totaled 67 peak kilowatts in 1992, a 10-percent increase from the corresponding level in 1991.

\section{Destination}

\section{Domestic}

The industrial sector was the largest market for photovoltaic cells and modules in 1992, accounting for 27 percent of total shipments (Table 26). This market involves the use of photovoltaic cells and modules, of which 98 percent were crystalline silicon and 2 percent were thin-film silicon cells and modules in 1992, to produce power for industrial applications including grid and non-grid systems. The industrial sector also represented the largest market for photovoltaic shiprnents in 1991.

Photovoltaic cells and modules used in grid-connected and remote (non-grid) photovoltaic systems to provide power for the residential sector was the second largest market for photovoltaics in 1992 (27 percent of total shipments). In contrast, in 1991 cells and modules 
Table 25. Shipments of Photovoltaic Cells and Modules by End Use and Type, 1991 and 1992 (Peak Kilowatts)

\begin{tabular}{|c|c|c|c|c|c|c|}
\hline End Uso & $\begin{array}{l}\text { Cryotalline } \\
\text { Silloon }\end{array}$ & $\begin{array}{l}\text { Thin-Film } \\
\text { Silloon }\end{array}$ & $\begin{array}{c}\text { Concentrator } \\
\text { Silloon }\end{array}$ & Other & $\begin{array}{l}1992 \\
\text { Total }\end{array}$ & 1991 Total \\
\hline $\begin{array}{l}\text { Electricity Generation } \\
\text { Grid Interactive } \ldots \ldots \ldots \ldots \ldots \ldots \\
\text { Remote } \ldots \ldots \ldots \ldots \ldots \ldots\end{array}$ & $\begin{array}{r}710 \\
4,178\end{array}$ & $\begin{array}{r}517 \\
24\end{array}$ & $\begin{array}{r}0 \\
37\end{array}$ & $\begin{array}{l}0 \\
0\end{array}$ & $\begin{array}{l}1,227 \\
4,238\end{array}$ & $\begin{array}{r}856 \\
3,594\end{array}$ \\
\hline $\begin{array}{l}\text { Communication } \ldots \ldots \ldots \ldots \ldots \\
\text { Consumer Goods } \ldots \ldots \ldots \ldots \\
\text { Transportation } \ldots \ldots \ldots \ldots \\
\text { Water Pumping } \ldots \ldots \ldots \ldots \\
\text { Cells/Modules to OEM } \ldots \ldots \ldots \ldots \\
\text { Health } \ldots \ldots \ldots \\
\text { Other } \ldots \ldots \ldots \ldots \\
\ldots \ldots \ldots \ldots\end{array}$ & $\begin{array}{r}3,700 \\
2,379 \\
1,470 \\
776 \\
806 \\
53 \\
384\end{array}$ & $\begin{array}{r}17 \\
181 \\
127 \\
32 \\
21 \\
14 \\
142\end{array}$ & $\begin{array}{l}0 \\
0 \\
0 \\
1 \\
0 \\
0 \\
2\end{array}$ & $\begin{array}{l}0 \\
6 \\
5 \\
0 \\
0 \\
0 \\
1\end{array}$ & $\begin{array}{r}3,717 \\
2,566 \\
1,602 \\
809 \\
828 \\
67 \\
530\end{array}$ & $\begin{array}{r}3,538 \\
3,312 \\
1,523 \\
729 \\
1,315 \\
61 \\
13\end{array}$ \\
\hline Total $\ldots \ldots \ldots \ldots \ldots$ & 14,457 & 1,075 & 40 & 11 & 15,583 & 14,939 \\
\hline
\end{tabular}

Note: Totals may not equal sum of components due to independent rounding.

Source: Energy Information Administration, Form CE-63B, "Annual Photovoltaic Module/Cell Manufacturers Survey."

Table 26. Shlpments of Photovoltalc Cells and Modules by Market and Type, 1991 and 1992 (Peak Kilowatts)

\begin{tabular}{|c|c|c|c|c|c|c|}
\hline Market Sector & $\begin{array}{l}\text { Crystalline } \\
\text { Sllicon }\end{array}$ & $\begin{array}{l}\text { Thin-Film } \\
\text { Sllicon }\end{array}$ & $\begin{array}{l}\text { Concentrator } \\
\text { Sllicon }\end{array}$ & Other & $\begin{array}{l}1992 \\
\text { Total }\end{array}$ & 1991 Total \\
\hline$\ldots \ldots \ldots \ldots$ & 4,203 & 74 & 2 & 0 & 4,279 & 3,947 \\
\hline Residential & 4,069 & 85 & 0 & 0 & 4,154 & 3,624 \\
\hline$\ldots \ldots \ldots \ldots$ & 2,211 & 168 & 1 & 6 & 2,386 & 3,345 \\
\hline Transportation $\ldots \ldots \ldots \ldots$ & 1,551 & 116 & 0 & 6 & 1,673 & 1,555 \\
\hline Utility $\ldots \ldots \ldots \ldots \ldots \ldots \ldots$ & 1,032 & 521 & 0 & 0 & 1,553 & 1,275 \\
\hline Government . . . . . . . . . . & 1,063 & (s) & 0 & 0 & 1,063 & 815 \\
\hline Other $\ldots \ldots \ldots \ldots \ldots \ldots \ldots$ & 329 & 111 & 37 & 0 & 477 & 377 \\
\hline Total & 14,457 & 1,075 & 40 & 11 & 15,583 & 14,939 \\
\hline
\end{tabular}

(s) $=$ Less than 500 peak watts.

Note: Totals may not equal sum of components due to independent rounding.

Source: Energy Intormation Administration, Form CE-63B, "Annual Photovoltaic Module/Cell Manufacturers Survey."

shipped to the residential market represented 24 percent of total shipments.

The commercial market was the third largest photovoltaic market, accounting for 15 percent of total shipments in 1992. These cells and modules were shipped to produce power for commercial establishments such as office buildings, private hospitals and schools (publicly owned hospitals and schools are listed under the government sector), and retail establishments. In contrast, the commercial sector accounted for 22 percent of total shipments in 1991.
Photovoltaic cells and modules for the transportation sector, which were used to produce power on boats, cars, and recreational vehicles and to power transportation support systems, amounted to 1.7 peak megawatts. The transportation sector accounted for 11 percent of total shipments in 1992 compared with 10 percent in 1991.

Shipments to the utility sector, where cells and modules were used to produce power at utility-owned systems including central stations, decentralized systems, and experimental applications, amounted to 1.6 peak 
megawatts in 1992, a 22-percent increase rrom the 1991 level.

Shipments of photovoltaic cells and modules used to produce power for branches of Federal, State, or local governments (including military) totaled 1.1 peak megawatts in 1992 . This compares with 0.8 peak megawatts shipped to the government sector in 1991. The "Other" sector (Table 26) consists of 0.5 peak megawatts shipped to foreign governments and for specialty purposes in 1992.

\section{Exports}

Export shipments totaled 10 peak megawatts in 1992 , an increase of 10 percent from the 1991 level (Table 18). Generally, exports have increased at about the same pace as total shipments because of the continued search for new photovcltaic markets outside the United States (Figure 4). Seventeen of the 21 reporting companies exported photovoltaic cells and modules, and exports accounted for 63 percent of total photovoltaic shipments in 1992. The major type of cells and modules exported in 1992 were crystalline silicon (98 percent)(Table 27). Destination of photovoltaic exports by continent is shown in Table 28. Countries named as the destination of exports are listed in Table 29.

\section{Systems}

Of the 25 companies reporting shipments of photovoltaic systems in 1992, 7 reported shipments of 232 complete photovoltaic systems (Table 30 ). A complete photovoltaic system is defined as a power supply unit that satisfies all the power requirements of an application. Such a system is generally made up of one or more modules, a power conditioning unit to process the electricity into the form needed by the application, wires and other electrical connectors, and sometimes batteries for back-up power supply. Some complex, large-scale photovoltaic systrms use concentrators to focus solar rays onto a small photovoltaic cell and tracking systems to track the sun. In this report, installation materials such as the support frame and concrete foundations are not considered part of the system. Cost of systems reported in this document exclude excise taxes and charges for freight, transportation, and installation. Total value of complete systems shipped in 1992 was $\$ 7.4$ million. Six percent of all modules shipped were complete systems.

\section{Table 28. Destination of Photovoltalc Cell and Module Exports by Continent, 1992}

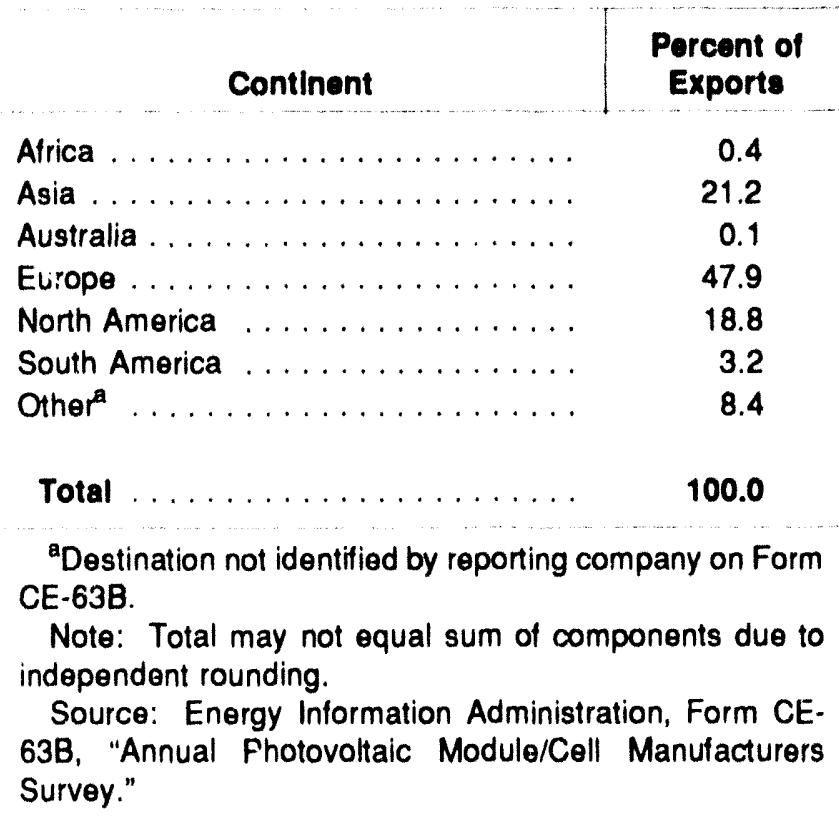

Table 27. Photovoltalc Shipments for Export, 1992

(Peak Kilowatts)

\begin{tabular}{|c|c|c|c|c|c|}
\hline & \multicolumn{5}{|c|}{ Type } \\
\hline & $\begin{array}{l}\text { Crystalline } \\
\text { Silicon }\end{array}$ & $\begin{array}{l}\text { Thin-Film } \\
\text { Silicon }\end{array}$ & $\begin{array}{l}\text { Concentrator } \\
\text { Silicon }\end{array}$ & Other & Total \\
\hline Module & 6,986 & 122 & 35 & 3 & 7,146 \\
\hline Cell & 2,676 & 0 & (s) & 0 & 2,676 \\
\hline Total & 9,662 & 122 & 35 & 3 & $\mathbf{9 , 8 2 3}$ \\
\hline
\end{tabular}

$(s)=$ Less than 500 peak watts.

Note: Total may not equal sum of components due to independent rounding.

Source: Energy Information Administration, Form CE-63B, "Annual Photovoltaic Module/Cell Manufacturers Survey." 
Table 29. Destination of Photovoltaic Cell and Module Exports by Countries Recelving Exports, 1992

\begin{tabular}{|c|c|c|}
\hline Country & $\begin{array}{c}\text { Peak } \\
\text { Kllowatts }\end{array}$ & $\begin{array}{c}\text { Percent } \\
\text { of } \\
\text { Exports }\end{array}$ \\
\hline Argentina $\ldots \ldots \ldots \ldots \ldots \ldots$ & 69 & 0.7 \\
\hline Australia . . . . . . . . . . . & 12 & 0.1 \\
\hline Bolivia ................ & 65 & 0.7 \\
\hline Brazil .................. & 2 & $(*)$ \\
\hline Canada $\ldots \ldots \ldots \ldots \ldots \ldots$ & 570 & 5.8 \\
\hline Chile $\ldots \ldots \ldots \ldots \ldots \ldots$ & 2 & $(*)$ \\
\hline China . . . . . . . . . . . . . & 11 & 0.1 \\
\hline Colombia . . . . . . . . . . & 7 & 0.1 \\
\hline Dominican Republic . . . . . . . . . & 3 & $(*)$ \\
\hline England $\ldots \ldots \ldots \ldots \ldots \ldots$ & 10 & 0.1 \\
\hline France $\ldots \ldots \ldots \ldots \ldots \ldots$ & 94 & 1.0 \\
\hline Germany . . . . . . . . . . . & 3,763 & 38.3 \\
\hline Hong Kong . . . . . . . . . . . . & 141 & 1.4 \\
\hline Hungary . . . . . . . . . . . . . & 3 & $(*)$ \\
\hline India $\ldots \ldots \ldots \ldots \ldots \ldots$ & 3 & $(*)$ \\
\hline Indonesia . . . . . . . . . . . & 169 & 1.7 \\
\hline Israel $\ldots \ldots \ldots \ldots \ldots \ldots \ldots$ & 32 & 0.3 \\
\hline Italy $\ldots \ldots \ldots \ldots \ldots \ldots$ & 230 & 2.3 \\
\hline Japan $\ldots \ldots \ldots \ldots \ldots \ldots \ldots$ & 1,305 & 13.3 \\
\hline Malaysia ................ & 160 & 1.6 \\
\hline 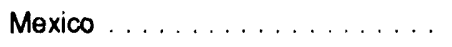 & 1,244 & 12.7 \\
\hline Netherlands $\ldots \ldots \ldots \ldots \ldots$ & 170 & 1.7 \\
\hline Nigeria $\ldots \ldots \ldots \ldots \ldots \ldots$ & 1 & $(*)$ \\
\hline Norway ................ & 169 & 1.7 \\
\hline Pakistan . . . . . . . . . . . . . & $(s)$ & $(*)$ \\
\hline 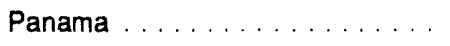 & 25 & 0.3 \\
\hline Philippines . . . . . . . . . & 4 & $(*)$ \\
\hline Portugal $\ldots \ldots \ldots \ldots \ldots \ldots$ & 32 & 0.3 \\
\hline 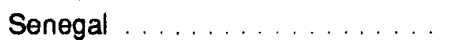 & (s) & (") \\
\hline Singapore $\ldots \ldots \ldots \ldots \ldots$ & 197 & 2.0 \\
\hline South Africa $\ldots \ldots \ldots \ldots \ldots$ & 38 & 0.4 \\
\hline Spain ................... & 10 & 0.1 \\
\hline Swaziland $\ldots \ldots \ldots \ldots \ldots$ & $(s)$ & (*) \\
\hline Sweden $\ldots \ldots \ldots \ldots \ldots \ldots$ & 39 & 0.4 \\
\hline Switzerland $\ldots \ldots \ldots \ldots \ldots$ & 181 & 1.8 \\
\hline 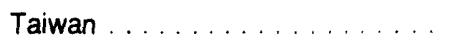 & 57 & 0.6 \\
\hline Thailand . . . . . . . . . . . . & 3 & $(*)$ \\
\hline United Kingdom . . . . . . . . . & 3 & $(*)$ \\
\hline Venezuela $\ldots \ldots \ldots \ldots \ldots \ldots$ & 101 & 1.0 \\
\hline$\ldots \ldots \ldots \ldots$ & (s) & $(*)$ \\
\hline Zambia $\ldots \ldots \ldots \ldots \ldots$ & (s) & $(*)$ \\
\hline Zimbabwe $\ldots \ldots \ldots \ldots \ldots$ & 4 & $(*)$ \\
\hline Unspecified $\ldots \ldots \ldots \ldots \ldots$ & 892 & 8.4 \\
\hline$\ldots \ldots \ldots$ & 9,823 & 100.0 \\
\hline
\end{tabular}

(") Represents less than 0.05 percent.

(s) Less than 500 peak watts.

Note: Total may not equal sum of components due to independent rounding.

Source: Energy Information Administration, Form CE-63B,

"Annual Photovoltaic Module/Cell Manufacturers Survey."
Table 30. Shlpments of Complete Photovoltalc Module Systems, 1990-1992

\begin{tabular}{|c|c|c|c|}
\hline Category & 1992 & 1991 & 1990 \\
\hline $\begin{array}{l}\text { Complete Photovoltaic } \\
\text { Systems Shipped (units) }\end{array}$ & 232 & 795 & 647 \\
\hline $\begin{array}{l}\text { Modules in Complete Systems } \\
\text { (peak kilowatts) . . . . . . }\end{array}$ & 781 & 89 & 409 \\
\hline $\begin{array}{l}\text { Modules in Systems as } \\
\text { Percent of Total Module } \\
\text { Shipments } \ldots \ldots \ldots \ldots\end{array}$ & 6 & 1 & 3 \\
\hline $\begin{array}{l}\text { Value of Complete Systems } \\
\text { (thousand dollars) } \ldots \ldots \ldots\end{array}$ & 7,409 & 5,625 & 7,766 \\
\hline
\end{tabular}

Source: Energy Information Administration, Form CE63B, "Annual Photovoltaic Module/Cell Manufacturers Survey."

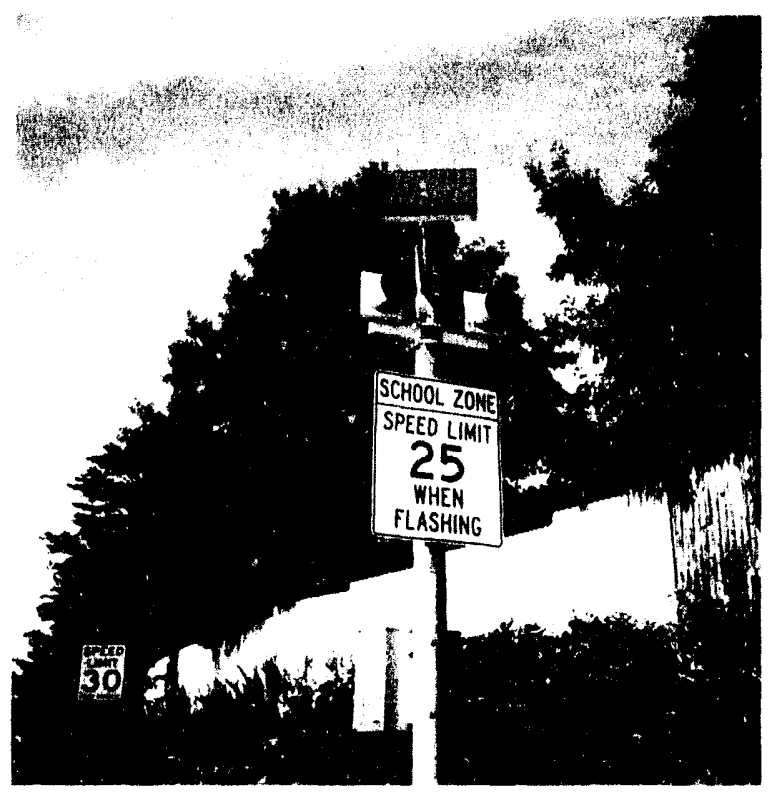

A traffic-warning light near Baltimore, Maryland, powered by a 40-peak-watt crystalline silicon photovoltaic module. 
Appendix A

Survey Methodology 


\section{Appendix A Survey Methodology}

\section{Survey Design}

The Energy Information Administration (EIA) conducts the "Annual Solar Thermal Collector Manufacturers Survey" (Form CE-63A), and the "Annual Photovoltaic Module/Cell Manufacturers Survey" (Form CE-63B). Appendix $B$ contains a copy of the survey forms. Forms CE-63A/B are used to collect data from all U.S.-based manufacturers and importers of solar collectors. The surveys cover a 12-month period, from January through December of each year.

Respondents to the surveys are required to report data on (1) manufacturing activities, employment, and plans; and (2) total shipments, including imports and exports, type of collectors, shipment value, and shipment origin and destination. Respondents are requested to report their shipments of solar thermal collectors in terms of square feet and shipments of photovoltaic cells and modules in terms of electrical capacity, expressed in peak kilowatts.

The data collected on Forms CE-63A/B are subject to various sources of error. These sources are: (1) coverage (the list of respondents may not be complete or, on the other hand, there may be double counting); (2) nonresponse (all that are surveyed may not respond or may not provide all information requested); (3) respondents (respondents may commit errors in reporting the data); (4) processing (the data collection agency may omit or incorrectly transcribe a submission); (5) concept (the data collection elements may not measure the items they were intended to measure); and (6) adjustments (errors may be made in estimating values for missing data). Because both of the surveys are census surveys, the estimates shown in this report are not subject to sampling error. ${ }^{3}$ Although it is not possible to present estimates of nonsampling error, precautionary steps were taken at each stage of the survey design to minimize the possible occurrence of these errors.

\section{Survey Universe and Frame}

The universe of the $\mathrm{CE}-63 \mathrm{~A} / \mathrm{B}$ respondents is a census of those U.S.-based companies involved in manufacturing and/or importing solar collectors. Care has been taken to establish the survey frames accurately. The frames of potential respondents are compiled from previous surveys and from information in the public domain. However, because the solar collector industry is subject to sporadic entry and exit of manufacturers and importers, the frame could possibly exclude some small companies that recently entered or reentered the industry.

The 1991 survey frames were updated in late 1992. The 1990 survey frames were updated in late 1991 and again in early 1992. Based on results from updates of the survey frames, data for 1990 (published in Solar Collector Manufacturing Activity 1990) were revised in the report, Solar Collector Manufacturing Activity 1991.

\section{Survey Procedures}

The survey forms were sent out via first class mail to ensure their receipt only by the proper respondent organization. If the U.S. Postal Service was unable to deliver a survey form, the corrected address was obtained where possible. In a few instances, businesses that reported in earlier surveys were no longer operating and therefore were eliminated from the survey frames. All known companies currently conducting business in the U.S. solar collector industry were contacted before and during this survey.

Approximately half of the respondents replied to the form within the specified initial deadlines. Those that did not were mailed another form specifying a new deadline. Those that had not responded by the second deadline were telephoned to encourage submission of

\footnotetext{
"Sampling error is a measure of the variation that occurs by chance because a sample rather than a complete enumeration of units is surveyed.
} 
the forms, and those calls resulted in the submission of most of the remaining forms. During the second round of calls, data were taken over the telephone whenever possible. Data received over the phone were entered on a blank survey form. Followup procedures were carried out to reduce the nonresponse rate and possible resulting bias.

\section{Data Editing, Analysis, and Processing}

Responses to the surveys were first edited manually to verify the accuracy of the reporting and to ensure reliability of the data. All individual company responses were also compared with the data reported in previous surveys. Wherever manual editing procedures indicated discrepancies or omissions, telephone calls were made to confirm or clarify the data. Data from manually edited forms were then entered into a computer and edited a second time via an automated procedure. After the second edit, a copy of each entry and tabulated computations were reviewed by an analyst familiar with the survey and with the solar collector industry and its companies.

\section{Response Rates}

The response rate for both surveys (Forms CE-63A/B) was 100 percent. The status of companies that were mailed CE-63A survey forms for the 1992 survey is shown in Table A1. The 1992 survey responses to surveys sent to 67 potential solar thermal collector companies resulted in the following performance statistics:

- Active companies: Forty-five (45) companies are known to have shipped solar thermal collectors during 1992.

- Inactive: Eighteen (18) companies on the mailing list had no shipments in 1992 but were kept on the list because they may have shipments in future years.

- Out of business: Three (3) of the companies were reported to be out of the solar thermal business during 1992, with no plans to reenter the business in a future year.

- Out of scope: One (1) company reported that it was not involved in solar thermal collector manufacturing or importing solar thermal collectors.
Table A1. Status of 1992 Survey Respondents

\begin{tabular}{c|c|c}
\hline & \multicolumn{2}{|c}{ Number of Companles } \\
\cline { 2 - 3 } Status & $\begin{array}{c}\text { Solar Thermal } \\
\text { (Form CE-63A) }\end{array}$ & $\begin{array}{c}\text { Photovoltaic } \\
\text { (Form CE-63B) }\end{array}$ \\
\hline Active $\ldots \ldots \ldots \ldots \ldots$ & 45 & 21 \\
Inactiv $\ldots \ldots \ldots \ldots$ & 18 & 18 \\
Out of Business $\ldots \ldots$ & 3 & 2 \\
Out of Scope $\ldots \ldots \ldots$ & 1 & 6 \\
Total $\ldots \ldots . \ldots$. & & 47 \\
\hline
\end{tabular}

Sources: Energy Information Administration, Form CE-63A, "Annual Solar Thermal Collector Manufacturers Survey," and Form CE-63B, "Annual Photovoltaic Module/Cell Manufacturers Survey."

The status of companies that were mailed CE-63B survey forms for the 1992 survey is shown in Table A1. The 1992 survey responses to surveys sent to 47 potential photovoltaic cell and module companies resulted in the following performance statistics:

- Active companies: Twenty-one (21) companies are known to have shipped photovoltaic cells or modules during 1992.

- Inactive: Eighteen (18) companies on the mailing list had no shipments in 1992 but were kept on the list because they may have shipments in future years.

- Out of business: Two (2) companies were reported to have exited the photovoltaic cell and module business during 1992, with no plans to reenter the business in the future.

- Out of scope: Six (6) companies reported that they were not involved in photovoltaic cell and module manufacturing or importing cells and modules.

\section{Incomplete or Missing Data and Imputation}

During the 1990 Form CE-63B survey period, one photovoltaic manufacturer was known to have shipped photovoltaic cells and modules during the first half of 1990. This photovoltaic company had gone out of business in the second half of 1990, and no data were acquired. For this company, one-half of the shipments reported for 1989 was used as the estimate of 1990 shipments. 
During 1986 the solar thermal collector manufacturing industry experienced a substantial slowdown in shipments as a result of the expiration of the solar tax credit at the end of 1985 and the reduction in energy prices. Reported shipments declined from 16.4 million square feet in 1984 to 4.9 million square feet in $1986 .{ }^{4}$ Many of the 1986 shipments probably occurred during the first quarter, as customers took delivery of materials purchased in late 1985 when solar tax credits were still available. The number of companies reporting and their reported shipments for the years 1984 through 1986 are presented in Table A2.

Table A2. Number of Reporting Companies and Shipments, 1984, 1985, and 1986

\begin{tabular}{|c|c|c|c|}
\hline Item & 1984 & $1985^{a}$ & 1986 \\
\hline Number of Companies & 224 & 116 & 97 \\
\hline Shipments (million square feet) & 16.4 & 11.1 & 4.9 \\
\hline $\begin{array}{l}\text { "Incomplete data. } \\
\text { Sources: } 1984-E n e r g y \text { Informatio } \\
\text { ElA-63, "Annual Solar Thermal Coll } \\
\text { Module Manufacturers Survey." } \\
\text { Information Administration, Form C } \\
\text { Thermal Collector Manufacturers Su }\end{array}$ & $\begin{array}{l}\text { Admi } \\
\text { lector a } \\
1985-1 \\
\text { SE-63A, } \\
\text { rvey." }\end{array}$ & $\begin{array}{l}\text { istration } \\
\text { id Photo } \\
986- \\
\text { "Annual }\end{array}$ & $\begin{array}{l}\text {, Form } \\
\text { ovoltaic } \\
\text { Energy } \\
\text { I Solar }\end{array}$ \\
\hline
\end{tabular}

Although reported shipments for 1985 were only 68 percent of those reported in 1984, it is likely that actual shipments were higher in 1985, which was believed to be a banner year because the energy tax credit expired at the end of the year. The number of companies reporting and, therefore, the reported shipments may have been low because many of the companies had gone out of business, and could not be located to collect the 1985 data when the data collection forms were mailed out more than a year later in early 1987. Shipment data for 80 companies that were in business all three years are presented in Table A3.

\section{Table A3. Shipments of Companies Reporting in 1984, 1985, and 1986}

\begin{tabular}{|c|c|c|c|}
\hline Item & 1984 & $1985^{\mathrm{a}}$ & 1986 \\
\hline Number of Companies $\ldots \ldots \ldots$ & 80 & 80 & 80 \\
\hline Shipments (million square feet) & 8.7 & 9.9 & 4.6 \\
\hline $\begin{array}{l}\text { ancomplete data. } \\
\text { Sources: } 1984 \text {-Energy Informati } \\
\text { ElA-63, "Annual Solar Thermal Co } \\
\text { Module Manufacturers Survey." } \\
\text { Information Administration, Form } \\
\text { Thermal Collector Manufacturers St }\end{array}$ & $\begin{array}{l}\text { n Admir } \\
\text { ector ar } \\
\text { 1985-1 } \\
\text { E-63A, } \\
\text { iey." }\end{array}$ & $\begin{array}{l}\text { istration } \\
\text { d Photo } \\
\text { "Annual }\end{array}$ & $\begin{array}{l}\text { Form } \\
\text { Enoltaic } \\
\text { Energy } \\
\text { I Solar }\end{array}$ \\
\hline
\end{tabular}

For the 80 companies that were in business all three of the years, 1984 through 1986, shipments increased 14 percent in 1985 but decreased 54 percent in 1986. Although not conclusive, this is an indication that if all shipments for all companies in business in 1985 were reported, there could have been a substantial increase from 1984 to 1985.

During the 1980 through 1983 survey periods for solar thermal collectors, imputed shipment data for nonrespondents were included (Tables 1 and 9). The imputed data are presented in Table A4.

Table A4. Imputed Solar Thermal Collector Shipments, 1980-1983

(Thousand Square Feet)

\begin{tabular}{|c|c|c|c|c|c|}
\hline \multirow{2}{*}{\multicolumn{2}{|c|}{ Year }} & \multirow{2}{*}{$\begin{array}{c}\text { Number of } \\
\text { Nonrespondents }\end{array}$} & \multicolumn{3}{|c|}{ Imputed Shipments } \\
\hline & & & Total $^{a}$ & Low-Teinperature ${ }^{b}$ & Medium-Temperature ${ }^{b}$ \\
\hline 1983 & & 21 & 1,624 & 1,327 & 297 \\
\hline 1982 & $\ldots$ & 9 & 249 & 106 & 143 \\
\hline 1981. & $\ldots$ & 79 & 1,771 & 338 & 1,433 \\
\hline 1980 . & $\ldots \ldots \ldots$ & 43 & 1,631 & 934 & 697 \\
\hline
\end{tabular}

amputed shipments included in total shipments.

Imputed shipments included in low-temperature and medium-temperature shipments.

Source: Energy Information Administration, Form EIA-63, "Annual Solar Thermal Collector and Photovoltaic Module Manufacturers Survey."

'The 1984 and 1986 shipment data stated here are the original survey data. These were revised by the Energy Information Administration (EIA) in Solar Collector Manufacturing Activity 1989, DOE/ElA-0174(89) (Washington DC, March 1991). The revised data shipments for 1984 are 17.2 million square feet, and 9.4 million square feet for 1986 . The revised data include shipments of parabolic dish/trough collectors to independent power producers to generate electricity for the electric grid. For the purposes of this analysis the original data are provided. 


\section{Data Revisions}

The Office of Coal, Nuclear, Electric and Alternate Fuels, Energy Information Administration, has adopted the following policy for review and correction (revision) of data it collects and publishes. The policy covers revisions to prior published data. This new policy is initially implemented with the publication of the Solar Collector Manufacturing Activity 1992.

1. Annual survey data are published either as preliminary or final when they first appear in a data report. Data released as preliminary will be identified as such. When necessary, preliminary data will be revised and declared to be final at the next publication of that data.

2. Monthly and quarterly survey data are published initially as preliminary data. They will be revised only after the completion of the data collection cycle for the full 12-month survey period. Revisions will not be made to monthly or quarterly data prior to this time.

3. The magnitude of historical data revisions experienced will be included in each data report to inform the reader about the accuracy of the data presented.

4. Revisions to data published as final will be made only in the event that newly available information would result in a change to published data of greater than one percent difference at the national level. Revisions for changes of lesser magnitudes will be made at the discretion of the Office Director.

All data from Forms CE63/A and CE-63/B are published as final data. All revised data are indicated by an " $R$ " in front of each revised data cell. No 1991 data were revised in this report.

\section{Nondisclosure of Data}

To protect the confidentiality of individual respondents' data, a policy was implemented to ensure that the reporting of survey data in this publication would not associate those data with a particular company. This is in compliance with EIA Standard No. 88-05-06, "Nondisclosure of Company Identifiable Data in Aggregate Cells." In tables where the nonzero value of a cell is composed of data from fewer than three companies or if a single company dominates a table-cell value so that the publication of the value would lead to identification of a company's data, then the EIA classifies the cell value as "sensitive," and the cell value is withheld ("W") from publication. Within a table with a sensitive cell value, selected values in other cells of the table are also withheld, as necessary, so that the sensitive cell value cannot be computed using the values in published cells.

A sensitive table-cell value can be reported, if permission is first obtained from each company (whose data contribute to the sensitivity) to publish the value. This is the only exception to the application of EIA Standard No. 88-05-06 in this report.

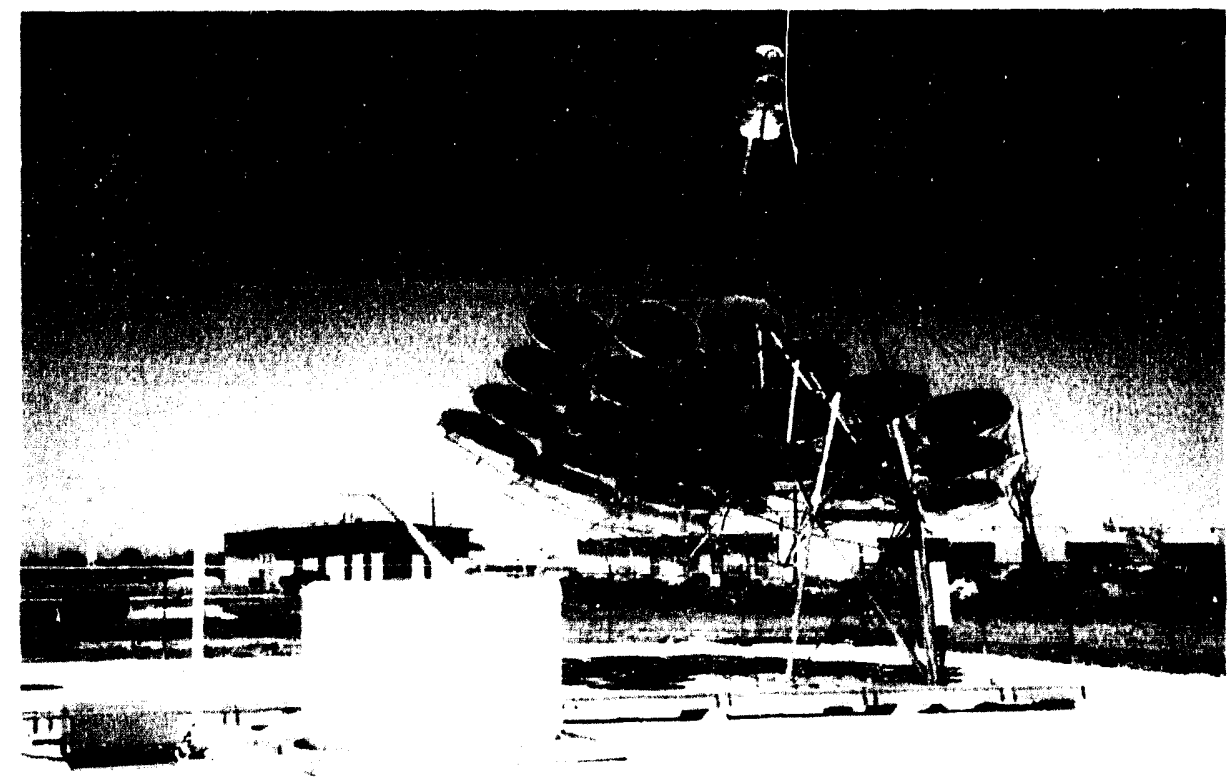

This 7.5-kilowatt dish-engine system developed and manufactured by Cummins Power Generation. Inc. of Columbus. Indiana, provides power for water pumping in Abilene. Texas. 
Appendix B

CE-63A/B

Survey Forms

and Instructions 
This report Is mandatory under FEA Act of 1974 (Public Law 93.275) and the Department of Energy Organizatlon Acl (Public Lew 95 -91). Provisiona regardine

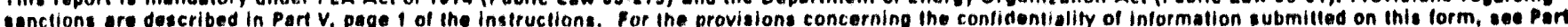
Vi of the instructions. Public reporting burden tor this collection of intormation ls estimaled to average 3 hours per response including the time reviewing instructions, oarching existing date sources, gathering and maintaining the dath needed, and compinting and reviewing ine collection of information. send

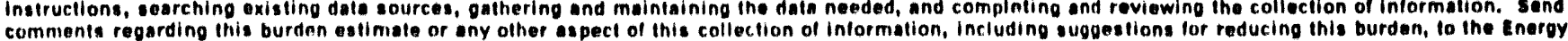
information Administration, Otfice of statistical standards, E1.73, 4000 independence Ave., sW. Weshington, D.C. 20585, end to ine Olfice of intormation and Regulatory Alfairs, Olfice of Management and Budget, Washington, O.C. 20503.

\section{The reporting perlod for this survey lo the calendar year 19}

For definitions and Instructions, plesee reler to the Oeneral Information and Instructions section of this form.

1.0 IDENTIFICATION DATA

1.1 Respondent Identification

Complete (a) inrough (d) only if label is incorrect

(a) Company Name:

(b) Street Address:

(c) City:

(d) State and Zip Code:

1.2 Provide the name, tille, and telephone number of a person in your company to whom quesllons may be addressed regarding this this submission.

(a) Name:

(b) Tille:

(c) Telephone:

Area Code Number

2.0 MANUFACTURINO status (Please refer 10 the "definition" section in the instructions for key words.)

2.1 During the current reporting period, did your company:

(a) Manufacture and ship solar thermal collectors?

(b) Cease manufacluring but continue to ship solar thermal collectors?

(c) Import and ship solar therinal collectors?

(d) Manulacture and export solar thermal collectors?

2.2 If you answered "No" to all parts of question 2.1, do you plan to manufacture, import, export, and ship solar thermal collectors in the huture? If yes, when? (year)

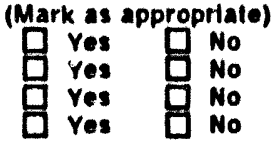

Note: If you answered "Yes" to any part of question 2,1, please complete the remainder of this form.

11 you answered "No" 10 all parts of question 2.1 , please complete question 8.0 and relurn inis form in the enclosed envelope or to the address specllied in the instructions.

\section{MANUFACTURER AND MARKETINO DATA}

3.1 Mark the appropriate box or boxes to Indicate all the solar.related activities in which your company was engaged during the survey year. Mark only those that apply to your solar activities.

(a) $\square$ Collector or system design

(b) $\square$ Prolotype collector development

(c) Drototype systems development

(d) Wholesale distribution

(0) Retail distribution

(n) installation

(q) Manufacfure of system.components other than those used for collector assembly

(h) Other (describe)

32 If you are planning to introduce new solar-related product in the next calendar year, please check the appropriate box.

(a) Low. Temperature Collector

(b) Mediun-Temperature Collector

(c) High-Temperafure Collector

(d) Noncollector Solar System Components

(o) 0 Other (describe)

33 please enter the number of person-years expended in your company in solar-related activities during the survey year. (For clarification of "person year," see the instructions.) person years.

34 What percentage of your company's lotal sales volume do solar-related activitles compose?

(a) $90 \cdot 100 \%$

(b) $50.89 \%$

(c) $10 \cdot 49 \%$

(d) Less than $10 \%$ 


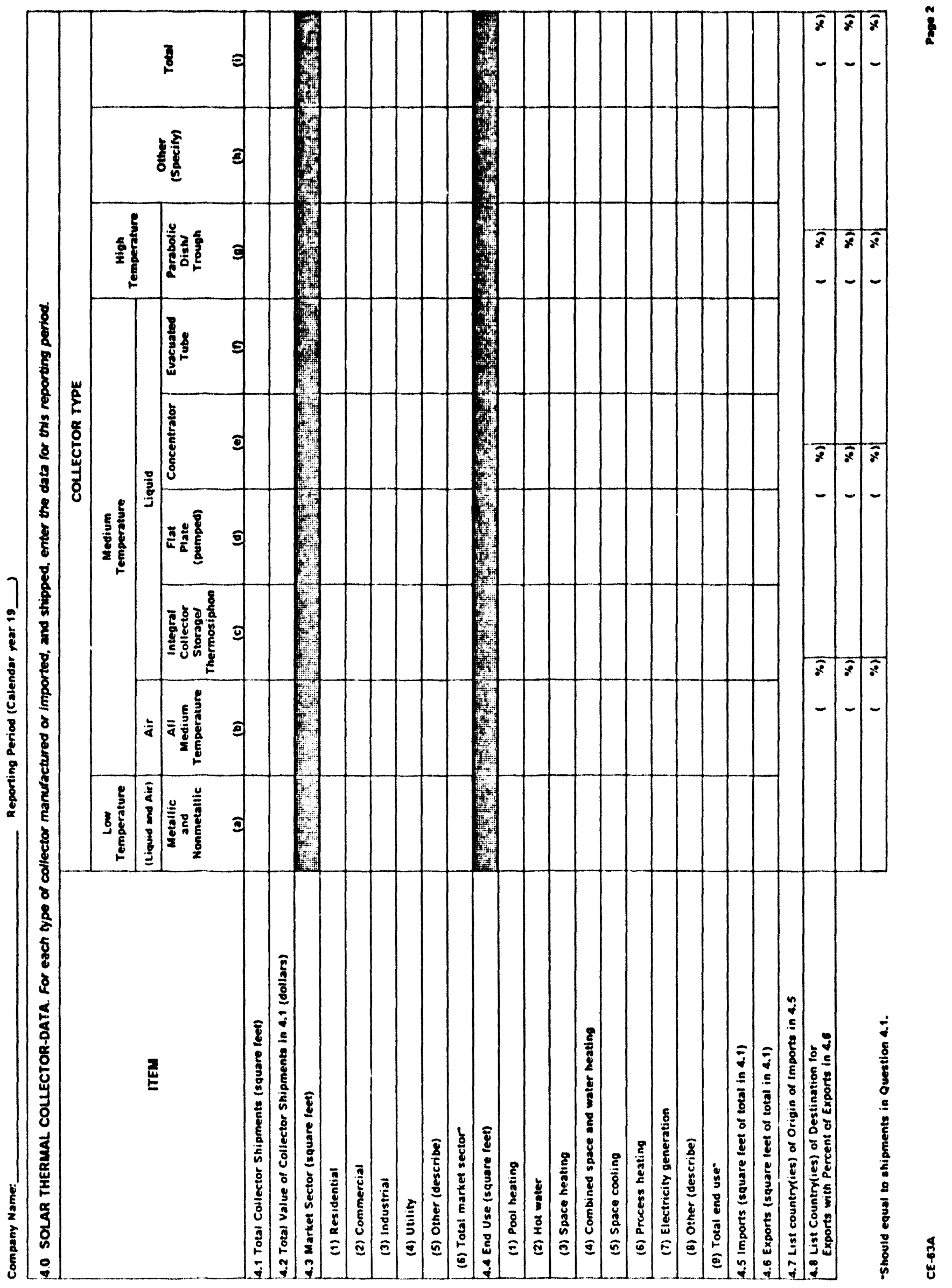



(a) Exporters
(b) Wholesele distributors
(c) Retall Distributore
(d) Installere
(e) End.Users
in oiner (dascribe)

TOTAL

\section{S.0 SYSTEMS DATA}

s.1 Or the tolal collector ehipments reported in question 4.1(1), how many complete ayateme were shipped (number of eveloms)?

5.2 Or the collector anioments reported in question 4.1(1), enter the square footage that was sold so part of complete aystems (aquare feet).

\section{0 ozooraphic data}

6.1 Report the percentage $(\%)$ of your company's collactors manufaclured in the state llsted below under Code Ot-53. If some colleclore were Imported Irom another country, please indicate the percentage under Code 00.

$$
\% \text { Collectors Imported }
$$

stale

Code

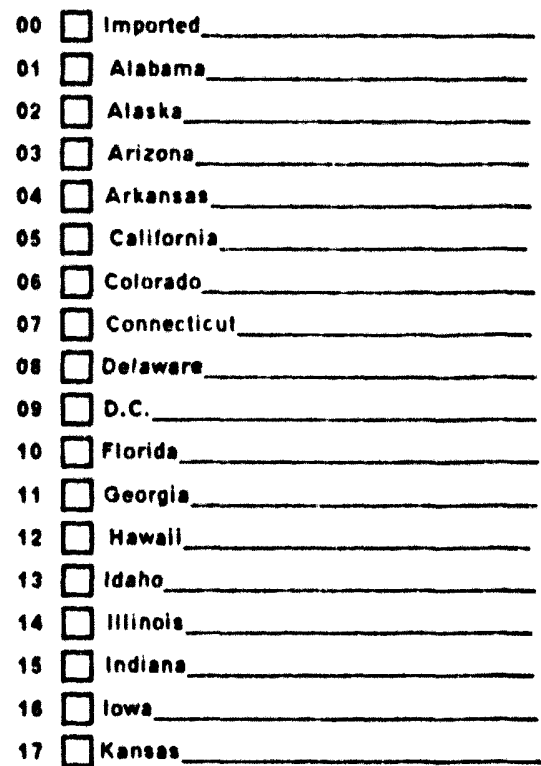

\section{or Manulactured}

in the state
\% Collector Importad

or Manulectured

in the slate
$\%$ Collector Imported

state

code or Manufactured

In the stole

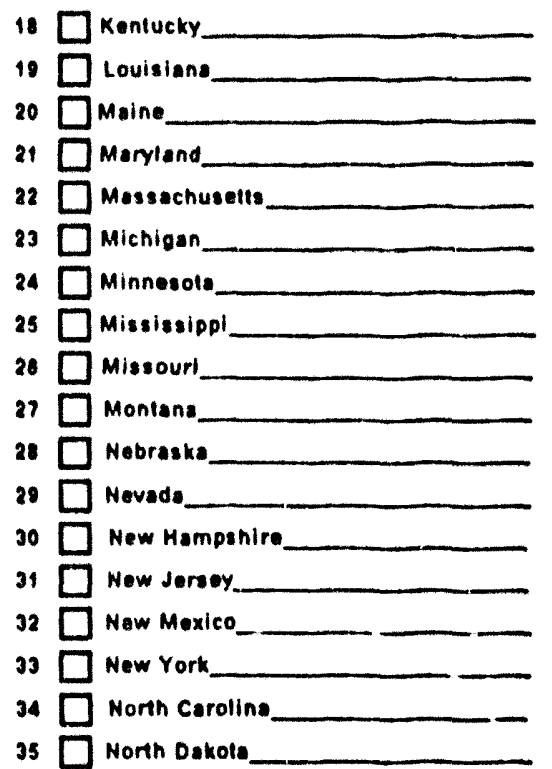

$36 \square$ Ohio $37 \square$ oklahoma $38 \square$ Oregon $39 \square$ Pennsyluanis $40 \square$ Puerto Rico $41 \square$ anode lsiand. $42 \square$ south Carolina $43 \square$ South Dakola $44 \square$ Tennessee. $44 \square$ Tennesses 45 Texas $16 \square$ Uian. $47 \square$ Vermont

$48 \square$ Viroin falands

$40 \square$ virginia so $\square$ Washington st $\square$ West Virginis $32 \square$ Wieconsin s3 $\square$ Wyoming 
6.2 Report the percentege $(\%)$ ol your company's collectore likely to have been shipped to the atale listed below under Code O1.53, this includes ahipmenta to the sale of manulacture. Il some collectors were exported, plesese indicale the percentage under Code oo.

\% Colleclors Exported

State

Code
\% Collectors Exported

or shipoed

to the siale
$\%$ Collectors Exported

or Shipped

to the state

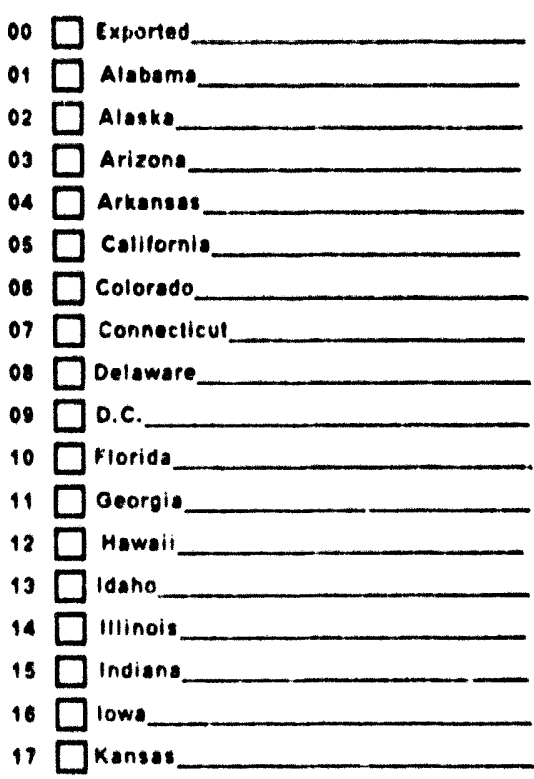

Code

$18 \square$ kentucky

$19 \square$ Louisiana

$20 \square$ Maine

$21 \square$ Marylend

$22 \square$ Massechusetts

$23 \square$ Michioen

$24 \square$ Minnesota

$25 \square$ Miselssipo

$26 \square$ Missourl

$27 \square$ Montana

28 [] Nebraska

$28 \square$ Nevads

$30 \square$ New Hampshire

$31 \square$ New Jersey

$92 \square$ New Mexico

33 New York

$34 \square$ North Carolin

$\square$ Norin Carolina

$35 \square$ North Dekola stote

Code

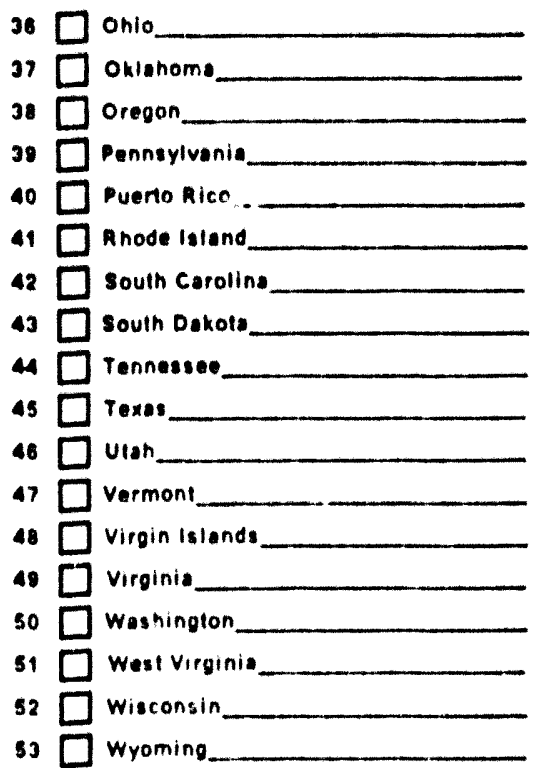

\subsection{PuBLICATION DATA}

7.1 Do you want the name and eddress of your company to appear in the appendix of the next - Solar Collector Manulacturing Activity report?

$\square$ Yes $\square$ No

7.2 Do you want to receive a copy of the next 'Solar Collector Manufacturing Activity redart?

\subsection{Certification}

I certity that the historical and estimated intormation provided hereon and appended hereto are inue, complete. and accurate to the best of my knowledge, informatioti, and beliet.

Name: Title:

Signature: Dale:

Enter ony additional remarks here:

Tille 18 U.S.C. 1001 makes 11 a crime lor any person knowingly and willingly lo make to any Agency of Department of ine United Stales any lalse. fictitious op fraudulent statement or misrepresentation os lo any maller within its jurisdiction. 


\title{
FORM CE-63A, ANNUAL SOLAR THERMAL COLLECTOR MANUFACTURERS SURVEY
}

\section{GENERAL INFORMATION AND INSTRUCTIONS}

\section{Purpose}

Form CE.63A is designed to provide the data necessary for the Eneroy Information Administration (EIA), U.S. Department of Energy (DOE), to carry out its responsibilities for tracking collector shipments in the solar collector manufacturing industry and for providing information concerning the size and status of the industry. The publication Solar Collector Manufacturing Activity 1992 will contain the results of this survey.

\section{Whe Should Resoend to This Surver}

Form CE.63A is to be submitted by companies (1) that manufactured and shipped lincluding exportingl solar thermal collectors and (2) that imported solar thermal collectors during the survey year. If you are completing this survey form for the first time but were active in the industry during the previous survey year, please photocopy the entire form and provide us with data for the previous year also.

III. Where to Submit Comoleted Forms

Completed and signed CE.63A forms should be returned to:

\author{
U.S. Depertment of Enorgy \\ Energy Information Administration. BG.094 \\ 1000 Independence Ave. SW \\ Washington, O.C. 20277.7091
}

Request for further information and/or additional forms may be mailed to the above address or telephoned to the surver project manager at (202) 254-5565.

\section{When 10 Submit Cempleted Forms}

Completed CE-63A forms are due on the date specified in the cover letter. The survey year is from January 1 through December 31 each year.

\section{Sanction:}

The timely submission of Form CE.63A by those required to report is mandatory under Section 13(b) of the Federal Energy Administration Act of 1974 (FEAA) (Public Law 93-275), as amended. Failure to respond may result in a civil penalty of not more than $\$ 2,500$ for each violation, or a fine of not more than $\$ 5,000$ for each willful violation. The government may bring a civil action to prohibit reporting violations which may result in a tempo ary restraining order or a preliminary or permanent injunction without bond. In such civil action, the court may also issue mandatory injunctions commanding any person to comply with these reporting requirements.

\section{Provision Regarding Confidentiality of Information}

The Otfice of Legal Counsel of the Department of Justice concluded on March 20, 1991, that the Federal Energy Administration Act requires the Energy Information Administration to provide company-specific data to the Department of Justice, or to any other Federal agency when requested for official use, which may include enforcement of Federal law. The information contained on this form may also be made available, upon request, to another component of the Department of Energy (DOE), to any Committee of Congress. the General Accounting Office, or other Congressional agencies authorized by law to receive such information. A court of competent jurisdiction may obtain this information in response to an order.

The information contained on this form will be kept confidential and not disclosed to the public to the extent that it satisfies the criteria for exemption under the Freedom of Information Act (FOIA), 5 U.S.C. 5552, the DOE regulations, 10 C.F.R. 1004.11 , implementing the FOIA, and the Trade Secrets Act, 18 U.S.C. 1905.

Upon receipt of a request for this information under the FOIA, the DOE shall make a final determination whether the information is exempt from disclosure in accordance with the procedures and criteria provided in the regulations. To assist us in this determination, respondents should demonstrate to the DOE that, for example, their information contains trade secrets or commercial or financial information whose release would be likely to cause substantial harm to their company's competitive position. A letter accompanying the submission that explains (on an element-by-element basis) the reasons why the information would be likely to cause the respondent substantial competitive harm if released to the public would aid in this determination. A new justification does not need to be provided each time information is submitted on the form. if the company has previously submitted a justification for that information and the justification has not changed. 
1.1 (a-d) Make corrections to the company name or address in the spaces provided.

1.2 (a.c) Enter the name, title, and telephone number of a company contact person who may be contacted for additional information regarding this submission.

2.1 (e-d) Mark as appropriate the manufacturing activity conducted by your company during the current reporting period. If you anewer "Yes" to eny one of (a) through (d) please begin with ltem 3.0 and complete the remainder of this form. If you answer "No" to all of (a) through (d) please complete only ltems 2.2 and 8.0.

2.2 If you answered "No" to all of liem 2.1. please mark whether your company plans to begin or continue any manufacturing activity and. If so, in what year.

3.1 (a-h) Report only on activities that are solar related.

3.2 (a-e) A now solar-related product is differentiated from a modified existing product if the "new" product is different though to warrant a new model number and requires retesting or recertification under existing industry standards.

3.3 Enter the total number of person-years expended on solar-related activities during the survey year. ISee definition of "Person Year" on page 4.1

3.4 "Solar-rolated activities" includes all activities listed in Item 3.1.

4.1 Enter the square footage (not the number of collectors), in whole numbers (i.e.. no decimals), of solar collectors by iype shipped for final consumption or to another organization for resale lincluding exports and imports) in the appropriate collector type column. Total (column i) should be the total square footage of all collector types in that row.

4.2 Enter the total value received for the total collector shipments in Item 4.1 by type. The value reported should be the total value received for collectors only at your company's net billing price, freight-on-board factory, including charges for cooperative advertising and warranties. Do not include excise taxes, freight. or transportation. Report values to the nearest dollar. Total (column i) should be the total value of all collector types in that row.

4.3 For each appropriate sector, enter the square footoge of collector shipments in ltem 4.1 by collector type as precisely as pussible. The market-sector categories in Item 4.3 are:

Part (1) Residential. Solar applications related to any building used for residential occupancy that has a system for heating or cooling, or both.

Part (2) Commercial. Solar applications for use in businesses where services (rather than products) are provided. such as wholesale and retail trade or health and educational services.

Part (3) Industrial. Solar applications for use in businesses where products (rather than services) are providec, such as the manufacture and processing of goods and basic materials.

Part (4) Utility. Shipments of solar thermal collectors to utilities for use in power generation or for experimental applications (includes gas and electric utilities). Includes central stations, decentralized systems or experimental applications.

Part (5) Other - Shipments of solar thermal collectors to other sectors such as "Government" (including the military).

Total market sector - Sum market sector quantities and onter a total for each row $[4.3(1) \cdot(5)]$ in column i. Next, sum columns o through $i$ and enter a total in row 4.3(6) for each column. These column totals should equal shipment totals entered under liem 4.1 by column. The total entered for $4.3(6)$ in column i should equal the total entered for Item 4.1 in column $\mathrm{i}$.

4.4 For each end use, enter the square footage of collector shipments in Item 4.1 by collector type as precisely as possible. The end-use categories in Item 4.4 are:

Part (1) Pool Heating - Self-explanatory.

Part (2) Hot Water - Shipments of solar thermal collectors used only for water heating.

Part (3) Space Heating - Shipments of solar thermal collectors used only for space heating.

Part (4) Combined space and water heating. Shipments of solar thermal collectors are used in combination for space and water heating.

Part (5) Space cooling - Shipments of solar thermal collectors used for space cooling (air conditioning) or for space cooling in combination with water and/or space heating.

Part (6) Process heating - Shipments of solar thermal collectors used for industrial process heating.

Part (7) Electricity Generation - Shipments of solar thermal collectors such as concentrators, linear fresnel lens. heliostats, parabolic dishes, and parabolic troughs used as steam generators to power electric generators.

Part (8) Other. Shipments of solar thermal collectors for other uses such as cooking food, water pumping. water purification. desalinization, distilling, etc. 


\section{SPECIFIC INSTRUCTIONS}

4.4 Total end use - Sum end.use quantities and enter a total for each row $(4.4(1) \cdot(8) 1$ in column 1 . Next. sum columns a through $i$ and enter a total in row 4.419$)$ for each column. These column totals should equal shipment totals entered under ltem 4.1 by column. The total entered for 4.419 in column i should equal the total entered for ltem 4.1 in column I.

4.5 Enter the square footage by collector type. This amount represents the portion of total collector shipments entered in Item 4.1 that were imported and shipped by your company.

4.6 Enter the square footage by collector type. This amount represents the portion of total collector shipments entered in Item 4.1 that were manufactured for export and shipped (sold) to another country.

4.7 List the countrylies) from which solar collectors reported in liem 4.5 were imported.

4.0 List the country(ies) to which solar collectors reported in ltem 4.6 were exported, and percent of exports in ltem 4.6 for each country listed.

4.9 Of the collectors reported in Item 4.1(i), report in square feet, the recipients of solar thermal collectors immediately following manufacturing or warehousing. If recipients overlap lfor example. the recipient is both a wholesale distributor and an installer) report the recipients in the higher category (i.e.. a is higher than $b, h$ is higher than $c$. etc.).

5.1 Enter number of complete systems shipped from the total in Item 4.1 (i).

5.2 Of the collectors reported in Item 4.1(i). enter the square footage that was sold as complete systems. IComplete system is defined as unit with all the necessary functional components. except for installation materials. These include thermosiphon systems, integral collector storage systems, packaged systems, or system kits.)

5.3 The value reported should be total value received for the complete systems at your company's net billing price, freight. on-board factory, including charges for cooperative advertising and warranties. Ilt should include the value of associated collectors.) Do not include excise taxes. treight or transportation charges, or installation charges. Report values to the nearest dollar.

6.1 Please identify only the State of final assembly of the collector. Please be certain to provide total percentage calculations.

6.2 Refers to collector shipments only. Indicate the last State of destination of which you are aware.

7.1 Mark as appropriate.

7.2 Mark as appropriate.

8.0 Selt-explanatory. 


\section{DEFINITIONS}

1. Air Collector - A medium-temperature solar thermal collector used predominantly in space-heating application and which utilizes pumped air as the heat-transfer medium.

2. Concentrator - A reflective or refractive device that focuses solar rays onto an area smaller than the reflective or refractive surface, resulting in higher intensity solar rays at the point of focus.

3. Evacuated-Tube Collector - A solar thermal collector in which the collector fluid flows through an absorber tube that is contained inside an evacuated glass cylinder.

4. Export (solar) - shipment of solar thermal collectors and/or photovoltaic devices sent from the United States and any of its territories to a foreign country.

5. Flat Plate (pumped) - A medium-temperature solar thermal collector, typically made with a metal frame, glazing. absorbers (usually metal), and insulation, that uses pumped liquid as the heat-transfer medium; predominantly used in water-heating applications.

6. High-Temperature Collectors - A solar thermal collector that generally operates at temperatures above 180 degrees Fahrenheit.

7. Import (solar) - A shipment of solar thermal collectors and/or photovoltaic devices into the United States and any of its territories from foreign countries.

8. Integral Collector Storage (ICS) - A solar thermal collector in which incident solar radiation is absorbed directly by the storage medium.

9. Liquid Collector - A medium-temperature solar thermal collector used predominantly in water heating, utilizing pumped liquid as the heat-transfer medium.

10. Low-Temperature Collectors - A solar thermal collector that generally operates at temperatures below 100 degrees Fahrenheit.

11. Medium-Temperature Collectors - A solar thermal collector that generally operates in the temperature range of 140 degrees Fahrenheit to 180 degrees Fahrenheit but can also operate at a temperature as low as 100 degrees Fahrenheit.

12. Parabolic Dish - A high temperature (above 180 degrees Fahrenheit) solar thermal concentrator, generally bowlshaped, with the capacity for tracking the sun using two axes of rotation.

13. Parabolic Trough - A high temperature (above 180 degrees Fahrenheit) solar thermal concentrator with the capacity for tracking the sun using one axis of rotation.

14. Person Year - One whole year, or fraction thereof, worked by an employee. It is expressed as a quotient (to two decimal places) of the time units worked during a year (hours, weeks, months) divided by the like total time units in a year. For example: 80 hours worked is 0.04 (rounded) of a person year; 3 weeks worked is 0.06 (rounded) of a person year; 12 months worked is 1.0 person year.

15. Solar Thermal Collector - A device designed to receive solar radiation and convert it into thermal energy. Normally, a solar thermal collector includes a frame, glazing, and an absorber, together with appropriate insulation. The heat collected by the solar thermal collector may be used immediately or stored for later use.

16. Thermosiphon System - A solar collector system for water heating in which circulation of the collection fluid through the storage loop is provided solely by the temperature and density difference between the hot and cold fluids. 


\section{Form CE-63B \\ U.S. DEPARTMENT OF ENEROY \\ Enorgy Information Administration \\ ANNUAL PHOTOVOLTAIC MODULEJCELL MANUFACTURERS SURVEY}

This report is mendabry under FEA ACt of 1874 (Public Law 93-275) and the Department of Enorgy Orparization Act (Public Law 95-91). Faiture b comply may result in criminal fines, civil penalties and other sanctions as provided by lew. For the provisions conceming the confidentedity of information submitted on this form, see Part Vl of the instructions. Public reporting burden for this collection of information is estimated to averege 3 hours per nesponso inctuding the timo reviewing instructions, searcting existing data sources, gathering and maintaining the data needed, end completing and reviewing the collectian of information. Send comments regarding this burden estimate or any other aspect of this collection of intormation, inctuding suggestions for reducing this burden, to the Energy Information Administration, Oliros of Statistical Standerda, E-73, Mai Station 1H-023 Forrestal, 1000 Independence Ave.. S.W., Washington,

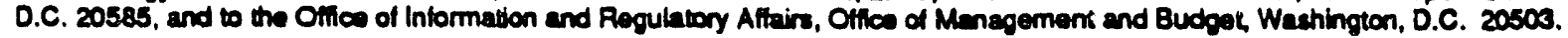

The reporting porlod for thls survey la calendar year 10

1.0 IDENTIFCATION DATA

For definitions and instructions, please refer to the General Information and Instructions section of this form.

1.1

Complete (a) through (d) only if label is incorrect:

(a) Company Name:

(b) Stroot Address:

(c) City:

(d) State and Zip Code:

1.2 Provide the name, title, and telephone number of a person in your company to whom questions may be addressed regarding this submission.
(a) Namo:
(b) Thto:
(c) Tolephono:
Area Code Number

20 MANUFACTUAING STATUS (Pleaze rofor to the "dofinition" soctlon for koy worda)

21 During the current reporting period, did your company:

(a) Manufacture and ship photovoltaic modules/colls?

(b) Cease manufacturing but continue to ship photovoltaic modules/cells?

(c) Import and ship photovoltaic modules/cells?

(d) Manufacture and export photovoltaic modules/calls?

2.2 If you answered "No" to all parts of question 2.1, do you plan to manufacture, import, export, and ship photovoltaic modules/cells in the future? If yes, when? ___ (year)

\begin{tabular}{llll}
\multicolumn{4}{c}{ (Mark as appropriato) } \\
$\square$ Yes & $\square$ & No \\
$\square$ & Yes & $\square$ & No \\
$\square$ & Yes & $\square$ & No \\
$\square$ & Yes & $\square$ & No
\end{tabular}

Note: If you answored "Yes" to any part of question 21, please complete the remainder of this form.

"I you answered No' to all parts of question 2.1, ploase complete question 7.0 and retum this form in the enclosed envelope or to the address specified in the instructions.

3.0 MANUfACTURER AND MARKETNG DATA

3.1 Mark the appropriate box or boxes to indicate all the photovoltaic-related activities in which your company was engaged in during this reporting poriod. Mark all that apply to your photovoltaic activitios only.
(a) Coll manufacturing
(b) $\square$ Module or system design
(c) $\square$ Prototype module devalopment
(d) Prototypo systems development
(e) Wholesale distribution of modules
(I) $\square$ Retail distribution of modules
(g) Installation
(h) Manufacture of system-components other than those used for module assembly
(i) $\square$ Other (describe):

3.2 If you are expecting to introduce new photovoltaic-rolated products in the next calendar year, please check the appropriate box(es).

(a) $\square$ Single-crystal silicon modules

(b) Cast silicon modules

(c) $\square$ Ribbon silicon modules

(d) Amorphous silicon modules

(e) $\square$ Other thin film

(i) $\square$ Other (llat plate) - spocity:

(g) Other (concentrator) - specity:

(h) $\square$ Nonmodule system components - specify:

3.3 Please enter the number of full-time-equivalent employees in your company that were engaged in photovoltaic-related activities during this reporting period. (For clarification of "full-time-equivalent," see the instructions.) 


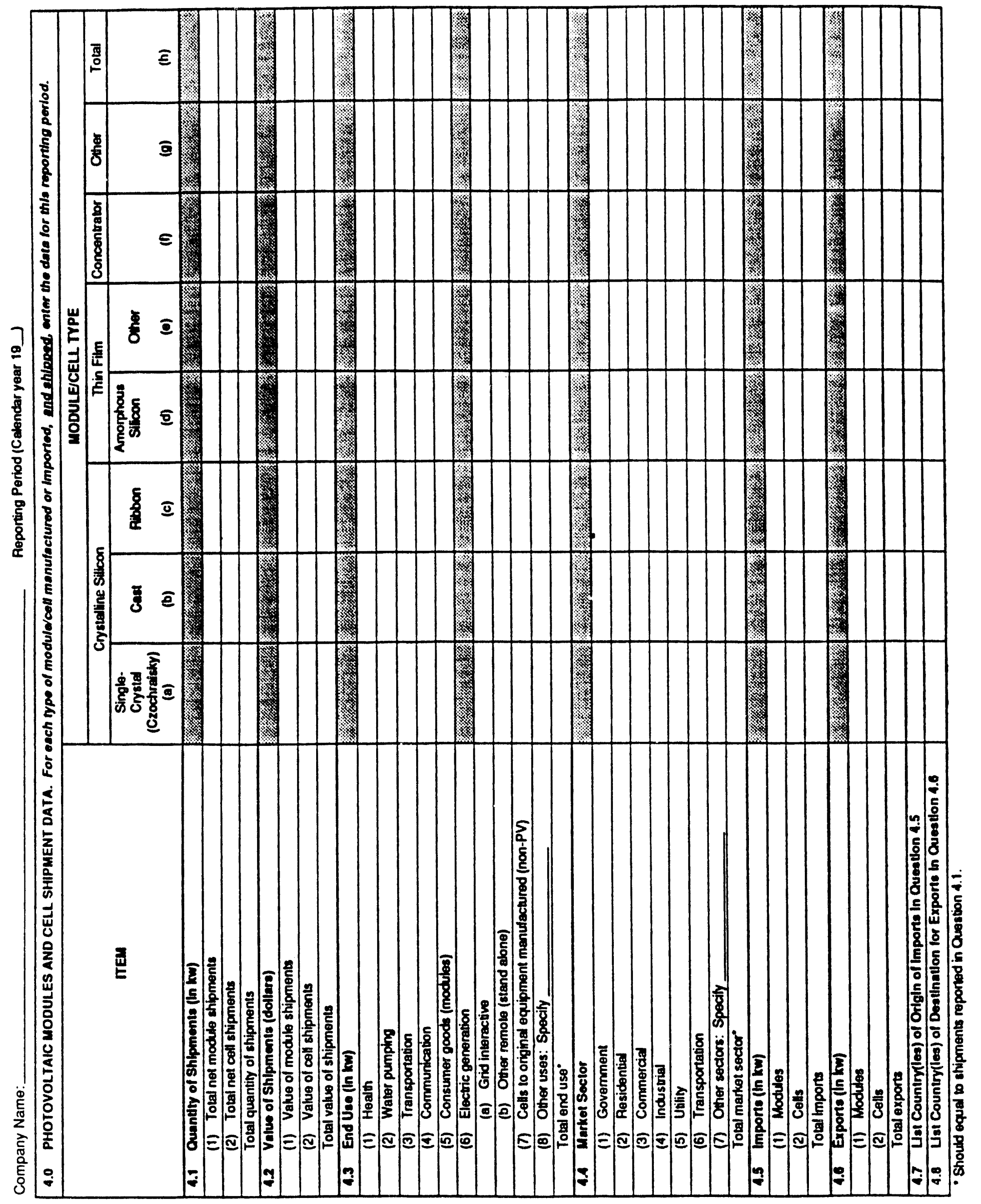


4.9 Enter the quantity (in kilowatts) of modules and cells reported in 4.1(1)(h) and $4.1(2)(h)$ that were shipped to:

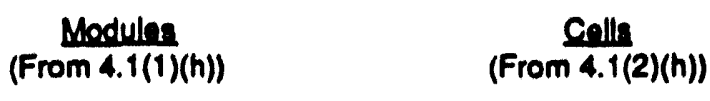

(a) Exportor

(b) Module Manufecturors

(c) Wholesalo Distributors

(d) Rotail Distributors

(o) Installor

(i) End-Users

(o) Other (describe)

TOTAL

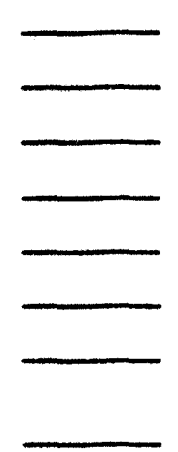
(From 4.1(2)(h))

5.0 TOTAL SHIPMENT DATA

5.1 Or the total modules shipped in $4.1(1)(h)$, how many complote systems were shipped (number of systoms)?

5.2 Of the modules shipped in 4.1(1)(h), enter the peak kilowatts that were sold as part of complete systems (klowatts).

5.3 What was the value of complote systems shipped in question 5.1 (dollars)?

\subsection{Publucation data}

6.1 Do you want the name and address of your company to appear in the appendix of the next Solar Collector Manufacturing Activity report?

Do you want to receive a copy of the next Solar Collector Manufacturing Activity repont?

\subsection{CERTIFICATION}

I certify that the information contained and appended is true and accurate to the best of my knowledge.

Name: Titio:

Signature: Date:

Enter any additional remarks here: 


\title{
FORM CE-63B, ANNUAL PHOTOVOLTAAC MODULE/CELL MANUFACTURERS SURVEY
}

\author{
GENERAL INFORMATION AND INSTRUCTIONS
}

\section{Purpose}

Form CE-63B is designed to provide the data necessary for the Energy Information Administration (EIA), U.S. Department of Energy (DOE), to carry out its responsibilities for tracking collector shipments in the solar collector manufacturing industry and for providing information concerning the size and status of the industry. The publication Solar Collector Manufacturing Activity 1992 will contain the results of this survey.

\section{Who Should Respond to This Survey}

Form CE-63B is to be submitted by companies that (1) manufactured and shipped (including exporting) photovoltaic cells and modules and (2) that imported photovoltaic cells and modules during the survey year. If you are completing this survey form for the first time but were active in the industry during the provious survey year, please photocopy the eiltire form and provide us with data for the previous year also.

\section{Where to Submit Completed Forms}

Completed and signed CE-63B forms should be returned to:

\author{
U.S. Department of Energy \\ Energy Information Administration, BG.094 \\ 1000 Independence Ave., SW \\ Washington, D.C. $20277-7091$
}

Request for further information and/or additional forms may be mailed to the above address or telephoned to the survey project manager at (202) 254-5565.

\section{When to Submit Completed Forms}

Completed CE-63B forms are due on the date specified in the cover letter. The survey year is from January 1 through December 31 each year.

\section{Sanctions}

The timely submission of Form CE-63B by those required to report is mandatory under Section $13(\mathrm{~b})$ of the Federal Energy Administration Act of 1974 (FEAA) (Public Law 93.275), as amended. Failure to respond may result in a civil penalty of not more than $\$ 2,500$ for each violation, or a fine of not more than $\$ 5,000$ for each willul violation. The government may bring a civil action to prohibit reporting violations which may result in a temporary restraining order or a preliminary or permanent injunction without bond. In such civil action, the court may also issue mandatory injunctions commanding any person to comply with these reporting requirements.

\section{Provisions Regarding Confidentiality Of Information}

The Office of Legal Counsel of the Department of Justice concluded on March 20, 1991, that the Federal Energy Administration Act requires the Energy Information Administration to provide company-specific data to the Department of Justice, or to any other Federal agency when requested for official use, which may include enforcement of Federal law. The information contained on this form may also be made available, upon request. to another component of the Department of Energy (DOE), to any Committee of Congress, the General Accounting Office, or other Congressional agencies authorized by law to receive such information. A court of competent jurisdiction may obtain this information in response to an order.

The information contained on this form will be kept confidential and not disclosed to the public to the extent that it satisfies the criteria for exemption under the Freedom of Information Act (FOIA), 5 U.S.C. \$552, the DOE regulations, 10 C.F.R. \$1004.11, implementing the FOIA, and the Trade Secrets Act, 18 U.S.C. \$1905.

Upon receipt of a request for this information under the FOIA, the DOE shall make a final determination whether the information is exempt from disclosure in accordance with the procedures and criteria provided in the regulations. To assist us in this determination, respondents should demonstrate to the DOE that, for example, their information contains trade secrets or commercial or financial information whose release would be likely to cause substantial harm to their company's competitive position. A letter accompanying the submission that explains (on an element-by-element basis) the reasons why the information would be likely to cause the respondent substantial competitive harm if released to the public would aid in this determination. A new justification does not need to be provided each time information is submitted on the form. if the company has previously submitted a justification for that information and the justification has not changed. 


\section{SPECIFIC INSTRUCTIONS}

1.1 (a-d) Make corrections to the company name or address in the spaces provided.

1.2 (a.c) Enter the name, title, and telephone number of a company contact person who may be contacted for additional information regarding this submission.

2.1 (a-d) Mark as appropriate the manufacturing activity conducted by your company during the current reporting period. If you answer "Yes" to any one of (a) through (d) please begin with ltem 3.0 and complete the remainder of this form. If you answer "No" to all of (a) through (d) please complete only Items 2.2 and 7.0.

2.2 If you answered "No" to all of Item 2.1. please mark whether you company plans to begin or continue any monufacturing activity, and if so, in what year.

3.1 (a-i) Report only on activities that are photovoltaic related.

3.2 (a-h) A new photovoltaic product is differentiated from a modified existing product if the "now" product is different enough to warrant a new model number and requires retesting or recertification under existing industry standards.

3.3 Enter the total number of person-years expended on photovoltaic-related activities during the survey year. ISee definition of "Person Year" on page 4.1

4.1 Quantity (in peak kilowatts) of photovoltaic module/cell shipments for terrestrial use only. Photovoltaic modules/cells intended for applications in space programs (satellites, military projects, etc.) are to be excluded.

Part (1) Total net module shipments. Enter the quantity in peak kilowatts (not the number of modules) of net photovoltaic modules shipped for final consumption or to another organization for resale lincluding exports and imports) in the appropriate module/cell type column. (Net photovoltaic module is defined on page 4.1 When exported, incomplete modules and un-encapsulated cells are also included. Total (column $\mathrm{h}$ ) should be the total peak kilowatts of all module types in that row.

Part (2) Total net cell shipments . Enter the quantity in peak kilowatts (not the number of cells) of net photovoltaic cells shipped to end-users or non-photovoltaic original equipment manufacturers lincluding exports and imports) in the appropriate module/cell type column. (Net photovoltaic cell is defined on page 4.1 Photovoltaic cells which are shipped to U.S. based photovoltaic module manufacturers should not be reported. Incomplete cells, such as wafers, should not be reported. Total (column h) should be the total peak kilowatts of all module types in that row.

Total quantity of shipments - Sum under $4.1(3)$ the quantities of $4.1(1)$ and $4.1(2)$ for all types (columns a through g) and Totals, (column h).

4.2 Value (in dollars) of photovoltaic module/cell shipments in ltem 4.1. The value reported should be total value received for modules/cells only at your company's net billing price. freight-on-board factory, including charges for cooperative advertising and warranties. Do not include excise taxes, freight, or transportation. Report values to the nearest dollar.

Part (1) Value of not module shipments - Enter under 4.2111 the total value of net photovoltaic modules in ltem 4.111). Total (column h) should be the total value of all module types in that row.

Part (2) Value of net cell shipments - Enter under $4.2(2)$ the total value of net photovoltaic cells in Item 4.1(2). Total (column $\mathrm{h}$ ) should be the total value of all cell types in that row.

Total value of shipments. Sum under $4.2(3)$ the values of $4.2(1)$ and $4.2(2)$ for all types (columns a through $\mathrm{g}$ ) and Totals, (column h).

4.3 For each end use, enter the peak kilowatt quantity of module/cell shipments in Item $4.1(3)$ by type as precisely as possible. The end-use categories in liem 4.3 are:

Part (1) Health - Photovoltaic modules/cells used in health/medical applications such as those used for powering medical refrigerators, medical equipment and for water purifications.

Part (2) Water Pumping. Photovoltaic modules/cells used for pumping water for agricultural, land reclamation. commercial and other similar applications where water pumping is the main use.

Part (3) Transportation. Photovoltaic modules/cells used on boats, cars, and recreational vehicles; and those used for transportation support systems such as signs. illumination, warning signals, etc.

Part (4) Communication - Photovoltaic modules/cells employed to power fixed base telecommunications equipment such as mountain-top repeater stations. Modules/cells issued for space applications are not to be included in this survey.

Part (5) Consumer goods. Photovoltaic modules/cells used to power products such as portable radios, toys, watches. calculators, small battery chargers, etc. (Please specify on the bases of stabilized full sun rating.)

Part (6) Electric Generation - Grid interactive and remote or stand alone power generation for general uses, including those for grid distribution and general remote uses like: residential power and power for mobile homes. 


\section{SPECIFIC INSTRUCTIONS}

4.3 Pant (7) To original equipment manufacturers (non-PV). Photovoltaic cells or modules shipped to non-photovoltaic original equipment manufacturers (OEM) that combines the cells into existing or newly developed product lines such as boats, cars, otc.

Part (8) Other uses - Shipments of photovoltaic cells and modules for other uses such as cooking food, desalinization, distilling, etc.

Total end use - Sum and.use quantities and enter a total for each row $(4.3(1) \cdot(8))$ in column h. Next, sum columns a through $h$ and enter a total in row $4.3(9)$ for each column. These column totals should equal shipment totals entered under ltem $4.1(3)$ by coluinn. The total entered for 4.319$)$ in column $h$ should equal the total entered for ltem $4.1(3)$ in column $\mathrm{h}$.

4.4 For each appropriate sector, enter the peak kilowatt quantity of module/cell shipments in Item $4.1(3)$ by type as precisely as possible. The mirket-sector categories in ltem 4.4 are:

Part (1) Government. Photovoltaic modules/cells for terrestrial use and employed to produce power for any branch of the U.S. Federal, Stute, and local government lincluding the military and including such uses as research. development, and demonstration projectsl. This excludes foreign government, which should be reported in ltem 4.4 Part (7). Other sectors.

Part (2) Residential - Photovoltaic modules/cells that are used in distributed, grid connected photovoltaic systems to provide power for residential applications.

Part (3) Commercial. Photovoltaic modules/cells employed to produce power for commercial establishments, such as office bulldings, private hospitals, private schools, retail establishments, etc. (Publicly owned schools. hospitals, and other institutions should be listed under government.)

Part (4) Industrial. Photovoltaic modules employed to produce power for industrial applications. Includes both grid and non-grid connected systems.

Part (5) Utility. Photovoltaic modules/cells used to produce power at an utility owned system including central stations, decentralized systems or experimental applications.

Part (6) Transportation - Photovoltaic modules/cells used to produce power on boats, cars, and recreational vehicles: and those used to power transportation support systems such as signs, illumination, warning signals, etc.

Part (7) Other sectors - Self explanatory.

Total market sector. Sum market sector quantities and enter a total for each row $(4.4(1)-(7)]$ in column $\mathrm{h}$. Next, sum columns a through $h$ and enter a total in row $4.4(8)$ for each column. These column totals should equal shipment totals entered under Item $4.1(3)$ by column. The total entered for $4.4(8)$ in column $h$ should equal the total entered for ltem $4.1(3)$ in column $h$.

4.5 Quantity (in peak kilowatts) of imported photovoltaic modules/cells that represents the portion of photovoltaic shipments entered in Item 4.1 (1) and (2) by module/cell type that were imported and shipped by your compe,ly.

Part (1) Modules - Enter the peak kilowatts of imported photovoltaic modules by type. This amount represerts the portion of total shipments in Item 4.111). Total (column h) should be the total peak kilowatts of all im sorted module types in that row.

Part (2) Cells - Enter the peak kilowatts of imported photovoltaic cells by type. This amount represents the iortion of total shipments in Item $4.1(2)$. Total (column $\mathrm{h}$ ) should be the total peak kilowatts of all imported cell types in that row.

Total Imports - Sum under $4.5(3)$ the quantities of $4.5(1)$ and $4.5(2)$ for all types (columns a through g) and Total, (column h).

4.6 Quantity (in peak kilowatts) of exported photovoltaic modules/cells that represents the portion of photovoltaic shipments entered in ltem $4.1(1)$ and $(2)$ by module/cell type that were exported by your company.

Part (1) Modules - Enter the peak kilowatts of exported photovoltaic modules by type. This amount represents the portion of total shipments in Item 4.1(1). Total (column $\mathrm{h}$ ) should be the total peak kiluwatts of all exported module types in that row.

Part (2) Colls . Enter the peak kilowatts of exported photovoltaic cells by type, including those cells that were shipped to foreign photovoltaic module manufacturers. This amount represents the portion of total shipments in ltem $4.1(2)$. Total (column $h$ ) should be the total peak kilowatts of all exported cell types in that row.

Total Exports . Sum under $4.6(3)$ the quantities of $4.6(1)$ and $4.6(2)$ for all types (columns a through $\mathrm{g}$ ) and Total. (column h).

4.7 List the country(ies) from which photovoltaic modules/cells reported in ltem 4.5 were imported.

4.8 List the country(ies) to which photovoltaic modules/cells reported in Item 4.6 were exported, and percent of exports in liem 4.6 for each country listed.

4.9 Of the modules/cells reported in Item 4.1 (1) and (2), report in peak kilowatts, the recipients of modules/cells immediately following manufacturing or warehousing. If recipients overlap (for example, the recipient is both a wholesaler distributor and an installer). report the recipients in the higher category (i.e., $a$ is higher than b. b is higher than c, etc.l. 


\section{SPECIFIC INSTRUCTIONS}

liem

instructions

5.1 Enter the number of complete systems shipped from the total modules in Item 4.111 ) (column $\mathrm{h}$ ).

5.2 Of the modules reported in Item $4.1(1)(\mathrm{h})$. enter the peak kilowrits that were sold as complete systems. (Complete system is defined as anit with all the necessary functional components, except for installation materials.)

6.3 The value reported should be the total value recelved for the complese systems at your company's net billing price. freight-on-boord factory, including charges for cooperotive advertising and warranties. Iit should include the value of the associated modules.i Do not include excise taxes, froight or trensportation charges, or installation charges. Report values to the nearest dollar.

6.1 Mark as appropriate.

7.0 Self-explanatory.

\section{DEFINITIONS}

1. Amerohous silicon - An alloy of silica and hydrogen, with an irregular internal atomic arrangement, that can be deposited in thin-film layers (a fow micrometers in thickness) by means of a number of deposition methods to produce thin-film photovoltaic cells on glass. metal, or plastic substrates.

2. Cast sllicen - Crystalline silicon obtained by pouring pure molten silicon into a vertical mold and adjusting the temperature gradient along the mold volume during cooling to obtain slow, vertically-advancing crystallization of the silicon. The polycrystalline ingot thus formed is composed of large, relativaly parallel, interlocking crystals. The cast ingots are sawed into wafers for further fabrication into photovoltaic cells. Cast-silicon waters and ribbon-silicon sheets fabricated into cells are usually referred to as polycrystalline photovoltaic cells.

3. Concentrater. A reflective or refractive device that focuses solar rays onto an ares smaller than the reflective or refroctive surface, resulting in higher intensity solat rays at the point of focus.

4. Expert (soler). A shipment of solar thermal collectors and/or photovoltaic devices sent from the United States and ony of its territories to a foreign country.

5. Impert (solar) - A shipment of solar thermal collectors and/or photovoltaic devices into the United States and any of its territorles from foreign countries.

6. Peak Kilowatt $\left(k W_{0}\right)$ - One thousand peak watts.

7. Net Photevoltaic Cell Shipment. The difference between photovoltaic cell shipments and photovoltaic cell purchases.

8. Net Photovoltaic Module Shipment - The difference between photovoltaic module shipments and photovoltaic module purchases.

9. Peak Watt - A manufacturer's unit indicating the amount of power a photovoltaic cell or module will produce at standard test conditions (normally 1,000 watts per square meter and 25 degrees Celsius).

10. Person Year. One whole year, or fraction thereof. worked by an employee. It is expressed as a quotient lto two decimal places) of the time units worked during a year (hours, weeks, months) divided by the like total time units in a year. For example: 80 hours worked is 0.04 (rounded) of a person-year; 3 weeks worked is 0.06 (rounded) of a person-year; 12 months worked is 1.00 person-year.

11. Photovoltoic Cell . An electronic device consisting of layers of semiconductor materials fabricated to form a junction ladjacent layers of materials with different electronic characteristics) and electrical contacts. and being capable of converting incident light directly into electricity (direct current).

12. Photevoltaic Module. An integrated assembly of interconnected photovoltaic cells designed to deliver a selected level of working voltage and current at its output terminals, packaged for protection against environment degradation, and suited for incorporation in photovoltaic power systems.

13. Ribbon Silicon - Sheets of crystalline silicon fabricated by a variety of solidification (crystallization) methods whereby thin silicon sheets are withdrawn from a pool of relatively pure molten silicon. The methods include: edge-defined, film. fed growth (EFG) and dendritic.web growth.

14. Silicon-A nonmetallic element with atomic number 14 and valence of 4 . It occu s extensively in earth's crust as silica $\left(\mathrm{SiO}_{2}\right)$ and silicates $\left(\mathrm{SiO}_{2}+\right.$ other elements and/or molecules). As a chemically aitered extract, silicon is used in alloys and electronic devices such as photovoltaic cells.

15. Single Crystal Silicen (Czochralski) . An extremely pure form of crystalline silicon produced by the Czochralski method of dipping a single crystal seed into a pool of molten silicon under high vacuum conditions and slowly withdrawing a solidifying single crystal boule of silicon. The boule is sawed into thin silicon wafers and fabricated into single-crystal photovoltaic cells. 


\section{Appendix C}

\section{Respondents to the 1992 Solar Thermal Collector Manufacturers Survey (Form CE-63A)}

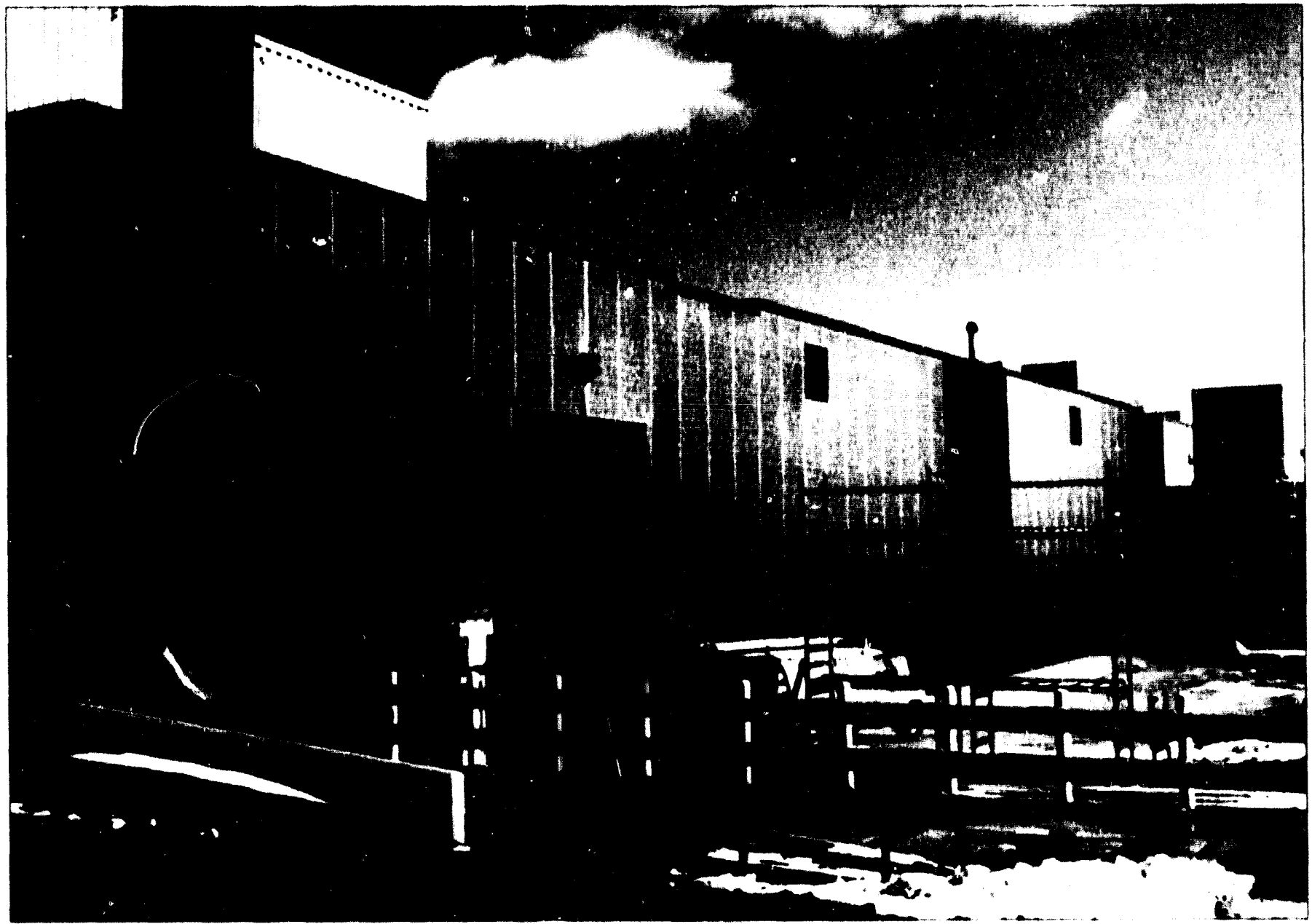




\section{Appendix C \\ Respondents to the 1992 Solar Thermal Collector Manufacturers Survey (Form CE-63A)}

Of the companies reporting data on Form CE-63A, 43 gave permission to have their company name and address listed in this publication.

Access Technology Corporation

36) Center Street

Bangor, Maine (440)1

American Energy Technologies

P.O. Box 1865

Creen Cove Springs, Florida 32043

American Solar Network, l.td.

5480) Gibbons Drive, Suite H

Carmichael, California 9560)8

Applied Solar Products

4580 Almaden Expressway

San Jose, California 95118

Aquatherm Industries, Inc.

1985 Rutgers University Blvd.

Lakewond, N('w Jersey (0870)1

Astron Technologies

4(0)1 Atlantic Avenue

Raleigh, North Carolina 27614

Bio-Energy Systems, Inc.

P.O. Box 191

48 Canal St.

Ellenville, New' York 12428

Caribe Soll De Puerto Rico

Apartado 190)

Mayaguez, Puerto Rico (0)7(x)

Conserval Systems, Inc.

2211 Main St., Building B

Buffalo, New York 14214

Contemporary Systems, Inc.

Route 12

Walpole, New I lampshire (0,361)8
Cummins Power Cieneration, Inc.

Box 30(0)5

Columbus, Indiana $472(2$

Energy Concepts Co.

627 Ridgely Avenue

Annapolis, Maryland 214()1

FAFCO, Inc.

2690) Middleficld Road

Redwood City, California 94063

GS Energy Industries, Inc.

108 Jefferson Avenue

Des Moines, lowa 50314

Haleakala Resources, Inc.

250) Alamaha Place, S-6

Kahului, Hawaii 96732

Heliocol USA, Inc.

927 Fern Street, \#2(X)

Altamonte-Springs, Florida 32701

Heliodyne Corporation

4910 Seaport Avenue

Richmond, California 94804

Industrial Solar Technology

5771 West 52nd Avenue

Denver, Colorado 80212

Keenan Solar, Inc.

7000 SW 22nd $\mathrm{Ct} .127 \mathrm{C}$

Davic, Florida 33317

Nippon Electric Glass America, Inc. 650 E. Devon Avenue, Suite 110

Itasca, Illinois 60143

Puerto Rico Solar Products

PO Box 7()2

Moca, l'uerto Rico (00716 
Radco Products, Inc.

2877 Industrial Parkway

Santa Maria, California 93455

S \& L. Solar System Co., Inc.

PO Box 1535

Carolina, Puerto Rico 0)9884

Sage Advance Corporation

P.O. Box 23136

Eugene, Oregon 97402

Sealed Air Corporation

3433 Arden Road

Hayward, California 34545

SEMCO

90121 st, N.W.

Albuquerque, New Mexico 87104

SOLAHART USA

155 Mata Way, Suite 109

San Marcos, California 92069

Solar Alternative, Inc.

PO Box 739

Brattleboro, Vermont 05301

Solar Development, Inc.

3697 A Prospect Avenue

Riviera Beach, Flonida 33404

Solar Energy \& Resources, Inc.

PO Box 2929

Bayamon, Pucrto Rico (0)965)

Solar Living, Inc.

PO Box 12

Netcong, New Jersey (17857

Solar Specialists, Inc.

6825 Mercedes Avenue

Citrus Heights, Califomia 95621
SunEarth, Inc.

4315 Santa Ana Street

Ontario, California 91761

Sun Cilow Systems

P.O. Box 18324

Fountain Hills, Arizona 85268

Sun Qest, Inc.

1555 Rankin Avenue

Newton, North Carolina 28658

Sun Ray Solar Heaters

1943-A Friendship Drive

E. Cajon, California 92020

Sun Trapper Solar Systems, Inc.

134 West Rhapsody Drive

San Antonio, Texas 78216

Sunwalt Corporation

RFD Box 751

Addison, Maine (4606

Sun Works, Inc.

1001 NW 50th Street

Sunrise, Horida 33351

Thermal Conversion Technolugy, Inc.

PO Box 3887

Sarasota, Florida 34230

Thermomax USA, L.td.

1201 Louisiana Avenue

Winter Park, Morida 32789

Universal Solar Products, Inc.

PO Box 364(1)27

San Juan, Puerto Rico (0)(936

Virginia Solar Components, Inc.

Route 4, Box 87

Rustburg, Virginia 24588 


\section{Appendix D}

\section{Respondents to the 1992 Photovoltalc Module/Cell Manufacturers Survey (Form CE-63B)}

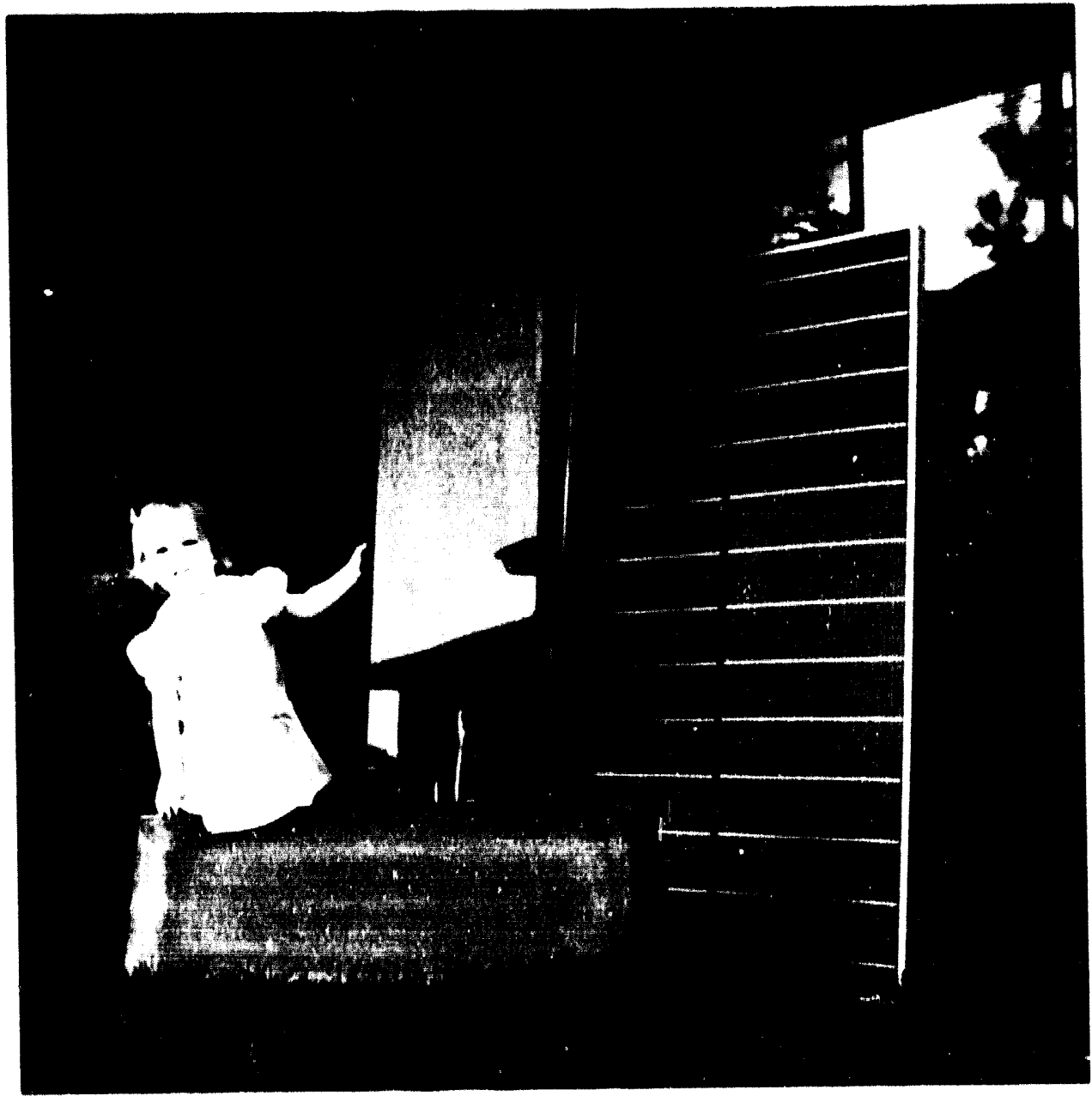

Thin-film photovoltaic modules, being tested for widespread utility use. 


\section{Appendix D \\ Respondents to the 1992 Photovoltaic Module/Cell Manufacturers Survey (Form CE-63B)}

Of the companies reporting data on Form (E-63B, 20 gave permission to have their company name and address listed in this publication.

AIS, Inc.

195 Clarksville Road

Lawrenceville, New Jersey 08648

Astrol'ower, Inc.

Solar Park

Newark, Delaware 19716

Blue Ridge Industrial Development Ciroup

304 Viewpoint Drive

Marion, North Carolina 28252

ENTECH, Inc.

PO Box 612246

DFW Airport, Texas 75261

EPV - Energy I'hotovoltaic

4326 US Route 1

Monmouth Jct., New Jerscy 08852

Hoxan America, Inc.

One Centennial Plaza, Suite $3 \mathrm{~F}$

Piscataway, New Jersey (88854

lowa Thin Film Technologies

ISU Research Park \#6()7

Ames, lowa 5(X)10

Kyocera America, Inc.

8611 Balboa Avenue

San Diego, California 92123

Midway Labs, Inc.

2255 E. 75th Street

Chicago, Illinois 60649

Mobil Solar Energy Corporation

4 Suburban Park Drive

Billerica, Massachusetts (01821
Sanyo Energy Corporation

2001 Sanyo Avenue

San Diego, California 92713

Siemens Solar Industries PO Box 6(1)32, 4560) Adhor Lane

Camarillo, California 93010

Soiarex Corporation

630) Solarex Court

Frederick, Maryland 21701

Solar Electric Enginecring, Inc. 1164 th Street

Santa Rosa, California 95401

Solec International, Inc.

12533 Chadron Avenue

Hawthorne, California 90250)

Spire Corporation

One Patriots Park

Bedford, Massachusetts 01730

SunPower Corporation

435 Indio Way

Sunnyvals, California 94086

Sunwatt Corporation

RFD Box 751

Addison, Maine 04606

Tideland Signal Corporation

PO Box 52430

Houston, Texas 77052

Translumin International, Inc.

1401 Northwest Boulevard

Franklin, Louisiana 70538 
Appendix E

U.S. Customary Units of Measurement, International System of Units (SI), and Selected Data Tables in SI Metric Units 


\section{Appendix E \\ U.S. Customary Units of Measurement, International System of Units (SI), and Selected Data Tables in SI Metric Units}

The standard factor for conversion between U.S. customary units and the International System of Units (SI) is shown in Table E1.

Table E1. Conversion Factor for U.S. Customary Units and SI Metric Units of Measurement

\begin{tabular}{ccc}
\hline To Convert From: & To: & Multiply by: \\
\hline $\begin{array}{c}\text { Square Feet } \\
\left(\mathrm{ft}^{2}\right)\end{array}$ & $\begin{array}{c}\text { Square Meters } \\
\left(\mathrm{m}^{2}\right)\end{array}$ & 0.09290304 \\
\hline
\end{tabular}

Note: The conversion factor is exact and all subsequent digits are zero.

Source Table $\mathrm{E} 1$ is patterned after Table 3, "Conversion Factors for SI Metric Units and U.S Customary Units of Measurement," in S.M. Long and A.M. Orellana, "The Metric System," in Suggestions to Authors of the Reports of the United States Geological Survey, Sixth Edition (U.S. Government Printing Office, Washington, DC, 1978), pp. $192-196$

\section{Selected Tables Converted to SI Metric Values}

The seven tables listed below contain data converted to equivalent metric values. The crosswalk given below shows the correlation between the tables of metric values and their corresponding tables in U.S. customary units in Chapter 1 of this report. No data tables from the "Photovoltaic Cell and Module Manufacturing Activities" chapter are converted to equivalent metric values.
Appendix E
Chapter 1
Table Number
Table Number

$\begin{array}{ll}\text { E2 } \ldots \ldots \ldots \ldots & \text { Table } 1 \\ \text { E3 } \ldots \ldots \ldots \ldots & \text { Table } 7 \\ \text { E4 } \ldots \ldots \ldots \ldots \ldots & \text { Table } 9 \\ \text { E5 } \ldots \ldots \ldots \ldots & \text { Table } 10 \\ \text { E6 } \ldots \ldots \ldots \ldots \ldots & \text { Table } 11 \\ \text { E7 } \ldots \ldots \ldots \ldots & \text { Table } 12 \\ \text { E8 } \ldots \ldots \ldots \ldots & \text { Table } 13\end{array}$


Table E2. Solar Thermal Collector Companles and Shlpments, 1974-1992 (Thousand Square Meters)

\begin{tabular}{|c|c|c|c|c|c|}
\hline & \multirow[b]{2}{*}{ Year } & \multirow{2}{*}{$\begin{array}{l}\text { Number of } \\
\text { Companles }\end{array}$} & \multicolumn{3}{|c|}{ Solar Thermal Collectors } \\
\hline & & & Total Shipments & Import Shipments & Export Shipments \\
\hline 1992 & $\ldots \ldots \ldots$ & 45 & 658 & 153 & 29 \\
\hline 1991 & $\ldots \ldots \ldots$ & 48 & 611 & 143 & 31 \\
\hline 1990 & $\ldots \ldots \ldots$ & 51 & 1,060 & 145 & 23 \\
\hline 1989 & $\ldots \ldots \ldots$ & 44 & 1,067 & 115 & 43 \\
\hline 1988 & $\ldots \ldots \ldots$ & 51 & 759 & 76 & 15 \\
\hline 1987 & $\ldots \ldots \ldots$ & 59 & 675 & 64 & 17 \\
\hline 1986 & $\ldots \ldots \ldots$ & 98 & 870 & 44 & 21 \\
\hline $1985^{a}$ & $\ldots \ldots \ldots$ & NA & NA & NA & NA \\
\hline 1984 & $\ldots \ldots \ldots$ & 225 & 1,597 & 58 & 32 \\
\hline $1983^{b}$ & $\ldots \ldots \ldots$ & 203 & 1,563 & 47 & 15 \\
\hline $1982^{b}$ & $\ldots \ldots \ldots$ & 265 & 1,730 & 39 & 42 \\
\hline $1981^{b}$ & $\ldots \ldots \ldots$ & 203 & 1,870 & 18 & 72 \\
\hline $1980^{b}$ & $\ldots \ldots \ldots$ & 233 & 1,802 & 22 & 104 \\
\hline 1979 & $\ldots \ldots \ldots$ & 349 & 1,324 & 27 & 79 \\
\hline 1978 & $\ldots \ldots \ldots$ & 340 & 1,009 & 37 & 78 \\
\hline 1977 & $\ldots \ldots \ldots$ & 321 & 958 & NA & NA \\
\hline 1976 & $\ldots \ldots \ldots$ & 186 & 539 & NA & NA \\
\hline 1975 & $\ldots \ldots \ldots$ & 131 & 348 & NA & NA \\
\hline 1974 & $\ldots \ldots \ldots$ & 45 & 118 & NA & NA \\
\hline
\end{tabular}

ancomplete data (see Appendix A).

bincludes imputation of shipment data to account for nonrespondents (see Appendix A).

$N A=$ Not available

Note: Total shipments include import and export shipments.

Sources: 1974-1977-Federal Friergy Administration telephone survey. 1978-1984-Energy Information Adrinistration, Form EIA-63, "Annual Solar Thermal Collector and Photovoltaic Module Manufacturers Survey." 1985-1992-Energy Information Administration, Form CE-63A, "Annual Solar Thermal Collector Manufacturers Survey."

Table E3. Five Top Solar Thermal Manufacturing States/Terrltories, 1991 and 1992

(Thousand Square Meters)

\begin{tabular}{c|l|r|r}
\hline Rank & & \multicolumn{2}{|c|}{ Shipments $^{\mathrm{a}}$} \\
\hline $1992 / 1991$ & Origin & 1992 & 1991 \\
\hline $1 / 1$ & California & 277 & 262 \\
$2 / 2$ & New York & 91 & 91 \\
$3 / 3$ & New Jersey & 90 & 75 \\
$4 / 5$ & Florida & 19 & 19 \\
$5 / 4$ & Puerto Rico & 19 & 14
\end{tabular}

Top Five Total . . . . . . . . . $496 \quad 461$

Includes domestic shipments and exports.

Note: Totals may not equal sum of components due to independent rounding.

Source: Energy Information Administration, Form CE-63A, "Annual Solar Thermal Collector Manufacturers Survey." 
Table E4. Solar Thermal Collector Shipments by Type, 1980-1992

(Thousand Square Meters)

\begin{tabular}{|c|c|c|c|c|c|}
\hline \multirow[b]{2}{*}{ Year } & \multicolumn{2}{|c|}{ Low-Temperature } & \multicolumn{2}{|c|}{ Medlum-Temperature } & \multirow{2}{*}{$\begin{array}{c}\text { Hlgh-Temperature } \\
\text { Shipments }\end{array}$} \\
\hline & Shipments & $\begin{array}{l}\text { Average Annual } \\
\text { Shipments per } \\
\text { Manufacturer }\end{array}$ & Shipments & $\begin{array}{l}\text { Average Annual } \\
\text { Shipments per } \\
\text { Manufacturer }\end{array}$ & \\
\hline$\ldots \ldots$ & 575 & 35.9 & 83 & 2.5 & (s) \\
\hline$\ldots \ldots$ & 519 & 32.4 & 92 & 2.2 & (s) \\
\hline $1990 \ldots \ldots$ & 339 & 28.2 & 235 & 5.7 & 487 \\
\hline $1989 \ldots \ldots$ & 398 & 39.8 & 185 & 5.1 & 484 \\
\hline$\ldots \ldots$ & 309 & 38.6 & 68 & 1.5 & 382 \\
\hline$\ldots \ldots$ & 293 & 24.4 & 89 & 1.8 & 293 \\
\hline$\ldots \ldots$ & 348 & 15.8 & 103 & 1.2 & 418 \\
\hline $1985^{b} \ldots \ldots$ & NA &.- & NA & -- & NA \\
\hline 1984 & 416 & 8.7 & 1,109 & 5.4 & 72 \\
\hline $1983^{c} \ldots \ldots$ & 451 & 8.2 & 1,113 & 6.2 & NA \\
\hline $1982^{C}$ & 695 & 11.4 & 1,035 & 4.2 & NA \\
\hline $1981^{c} \ldots \ldots$ & 806 & 10.7 & 1,064 & 4.1 & NA \\
\hline $1980^{c} \ldots \ldots$ & 1,136 & 14.4 & 666 & 2.7 & NA \\
\hline
\end{tabular}

${ }^{a}$ For high-temperature collectors, average annual shipments per manufacturer are not disclosed.

Incomplete data (see Appendix A).

Includes shipment data imputed for nonrespondents (see Appendix A).

$(\mathrm{s})=$ Less than 500 square meters. NA $=$ Not available, $\cdots=$ Not applicable.

Note: Totals may not equal sum of components due to independent rounding.

Sources: 1980-1984-Energy Information Administration, Form ElA-63, "Annual Solar Thermal Collector and Photovoltaic Module Manufacturers Survey." 1885-1992-Energy Information Administration, Form CE-63A, "Annual Solar Thermal Collector Manufacturers Sunvey." 
Table E5. Quantity, Value, and Average Price of Solar Thermal Collector Shipments by Type, 1991 and 1992

\begin{tabular}{|c|c|c|c|c|c|c|}
\hline Type & $\begin{array}{l}\text { Quantity } \\
\text { (thousand } \\
\text { square } \\
\text { meters) }\end{array}$ & $\begin{array}{l}\text { Value } \\
\text { (thousand } \\
\text { dollars) }\end{array}$ & $\begin{array}{c}\text { Average } \\
\text { Price (dollars } \\
\text { per square } \\
\text { meter) }\end{array}$ & $\begin{array}{c}\text { Quantity } \\
\text { (thousand } \\
\text { square } \\
\text { meters) }\end{array}$ & $\begin{array}{l}\text { Value } \\
\text { (thousand } \\
\text { dollars) }\end{array}$ & $\begin{array}{l}\text { Average } \\
\text { Price } \\
\text { (dollars per } \\
\text { square } \\
\text { meter) }\end{array}$ \\
\hline \multicolumn{7}{|l|}{ Low-Temperature } \\
\hline Liquid and Air . . . . . . . . . & 575 & 15,403 & 26.80 & 519 & 16,206 & 31.24 \\
\hline \multicolumn{7}{|l|}{ Medlum-Temperature } \\
\hline $\begin{array}{l}\text { Air } \ldots \ldots \ldots \ldots \ldots \ldots \\
\text { Liquid }\end{array}$ & (s) & 8 & 124.59 & $w$ & W & W \\
\hline ICS/Thermosiphon ........ & 28 & 3,825 & 136.08 & 24 & 4,965 & 205.33 \\
\hline Flat Plate . . . . . . . . & 54 & 5,441 & 100.31 & 65 & 6,375 & 97.62 \\
\hline Evacuated Tube ......... & W & $W$ & W & $W$ & W & W \\
\hline Concentrator $\ldots \ldots \ldots \ldots$ & W & $W$ & W & (s) & 275 & $2,355.03$ \\
\hline All Medium Temperature . . . . . . & 83 & 9,831 & 117.95 & 92 & 11,807 & 128.56 \\
\hline \multicolumn{7}{|l|}{ High-Temperature } \\
\hline Parabolic Dish and Trough & (s) & 148 & 814.95 & (s) & 23 & 343.85 \\
\hline Total & 658 & 25,382 & .- & 611 & 28,036 & $\ldots$ \\
\hline
\end{tabular}

$W=$ Data withheld to avoid disclosure. (s) = Less than 500 square meters. $\cdots=$ Not applicable.

Note: Totals may not equal sum of components due to independent rounding.

Source: Energy Information Administration, Form CE-63A, "Annual Solar Thermal Collector Manufacturers Survey."

Table E6. Shlpments of Solar Thermal Collectors by End Use and Type, 1991 and 1992 (Thousand Square Meters)

\begin{tabular}{|c|c|c|c|c|c|c|c|c|c|}
\hline \multirow[b]{3}{*}{ End Use } & \multirow{3}{*}{$\begin{array}{l}\text { Low- } \\
\text { Temperature } \\
\text { Liquid/Air } \\
\text { Metallic and } \\
\text { Nonmetallic }\end{array}$} & \multicolumn{5}{|c|}{ Medlum-Temperature } & \multirow{3}{*}{$\begin{array}{c}\text { High- } \\
\text { Temperature }\end{array}$} & \multirow[b]{3}{*}{$\begin{array}{l}1992 \\
\text { Total }\end{array}$} & \multirow[b]{3}{*}{$\begin{array}{l}1991 \\
\text { Total }\end{array}$} \\
\hline & & & \multicolumn{4}{|c|}{ Liquid } & & & \\
\hline & & Air & $\begin{array}{l}\text { ICS/ } \\
\text { Thermo- } \\
\text { siphon }\end{array}$ & $\begin{array}{l}\text { Flat-Plate } \\
\text { (Pumped) }\end{array}$ & $\begin{array}{c}\text { Evacu- } \\
\text { ated } \\
\text { Tube }\end{array}$ & $\begin{array}{l}\text { Concen- } \\
\text { trator }\end{array}$ & & & \\
\hline Pool Heating & 574 & 0 & 0 & 3 & 0 & 0 & 0 & 577 & 514 \\
\hline Hot Water & 0 & (s) & 26 & 48 & $w$ & $w$ & 0 & 74 & 92 \\
\hline Space Heating ... & 1 & (s) & 2 & 0 & (s) & 0 & 0 & 3 & 2 \\
\hline $\begin{array}{l}\text { Space Cooling } \ldots \ldots \ldots \\
\text { Combined Space and }\end{array}$ & 0 & 0 & 0 & 0 & $w$ & $w$ & (s) & (s) & (8) \\
\hline Water Heating .... & 0 & 0 & 0 & (s) & (s) & 0 & 0 & (s) & 1 \\
\hline Process Heating ... & 0 & 0 & (s) & 3 & 0 & 0 & (s) & 3 & 1 \\
\hline Electricity Generation & 0 & 0 & 0 & (s) & 0 & 0 & (s) & (8) & (s) \\
\hline Other $\ldots \ldots \ldots$ & 0 & 0 & 0 & 0 & 0 & 0 & (s) & (8) & (8) \\
\hline Total ..... & 575 & (8) & 28 & 54 & $w$ & $w$ & (8) & 658 & 611 \\
\hline
\end{tabular}

ICS = Integral Collector Storage.

$(s)=$ Less than 500 square meters. $W=$ Data withheld to avoid disclosure

Source: Energy Information Administration, Form CE-63A, "Annual Solar Thermal Collector Manufacturers Survey." 
Table E7. Shlpments of Solar Thermal Collectors by Market and Type, 1991 and 1992

(Thousand Square Meters)

\begin{tabular}{|c|c|c|c|c|c|c|c|c|c|}
\hline \multirow[b]{3}{*}{ Markel Sector } & \multirow{2}{*}{$\begin{array}{l}\text { Low- } \\
\text { Temperature } \\
\text { Liquid/Air }\end{array}$} & \multicolumn{5}{|c|}{ Medium-Temperature } & \multirow{3}{*}{$\begin{array}{c}\text { High- } \\
\text { Temperature }\end{array}$} & \multirow[b]{3}{*}{$\begin{array}{l}1002 \\
\text { Total }\end{array}$} & \multirow[b]{3}{*}{$\begin{array}{l}1901 \\
\text { Tolal }\end{array}$} \\
\hline & & & & Liqu & & & & & \\
\hline & $\begin{array}{l}\text { Metallic and } \\
\text { Nonmetallic }\end{array}$ & Air & $\begin{array}{l}\text { Thermo } \\
\text { siphon }\end{array}$ & $\begin{array}{l}\text { Flat-Plate } \\
\text { (Pumped) }\end{array}$ & $\begin{array}{l}\text { ated } \\
\text { Tube }\end{array}$ & $\begin{array}{l}\text { Concen. } \\
\text { Irator }\end{array}$ & & & \\
\hline Residential & 559 & (s) & 27 & 47 & w & $w$ & 0 & 634 & 587 \\
\hline Commercial & 15 & 0 & (s) & 4 & $w$ & $w$ & 0 & 19 & 21 \\
\hline Industrial & 1 & 0 & (s) & 1 & 0 & 0 & 0 & 3 & 1 \\
\hline Utility & 0 & 0 & (s) & 1 & 0 & 0 & 0 & 2 & 1 \\
\hline Other & 0 & 0 & (s) & (s) & 0 & 0 & (s) & (s) & (a) \\
\hline Total & 575 & (घ) & 28 & 54 & $w$ & $\mathbf{w}$ & (s) & 658 & 611 \\
\hline
\end{tabular}

ICS = Integral Collector Storage.

$(s)=$ Less than 500 square meters. $W=$ Data witheld to avoid disclosure

Note: Totals may no! equal sum of components due to independent rounding

Source: Energy Information Administration, Form CE-63A. "Annual Solar Thermal Collector Manufacturers Survey * 
Table E8. Shipments of Solar Thermal Collectors by Destination, 1991 and 1992

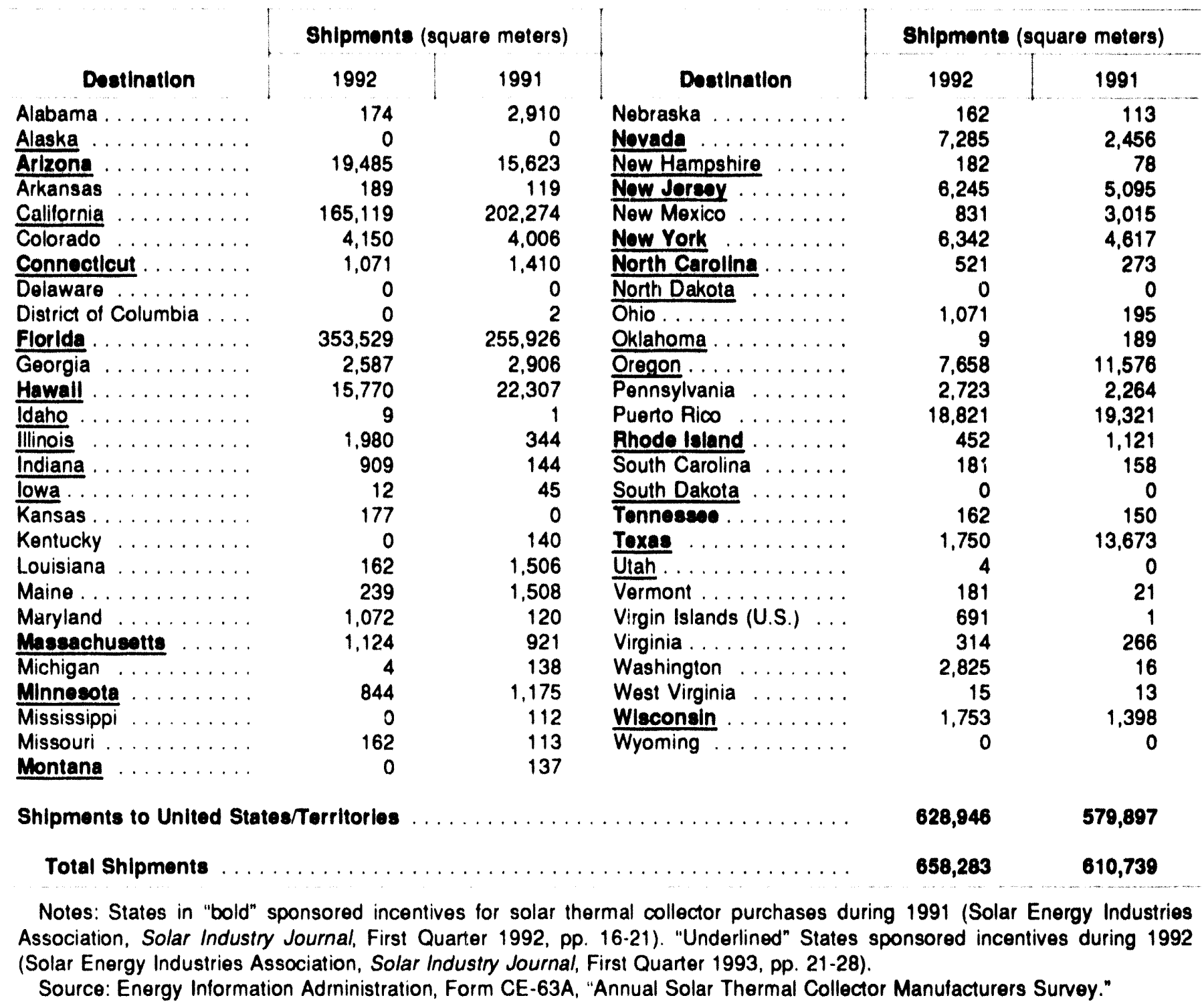




\section{Appendix F}

\section{Solar Collector Installed Capacity and Energy Production in the United States}

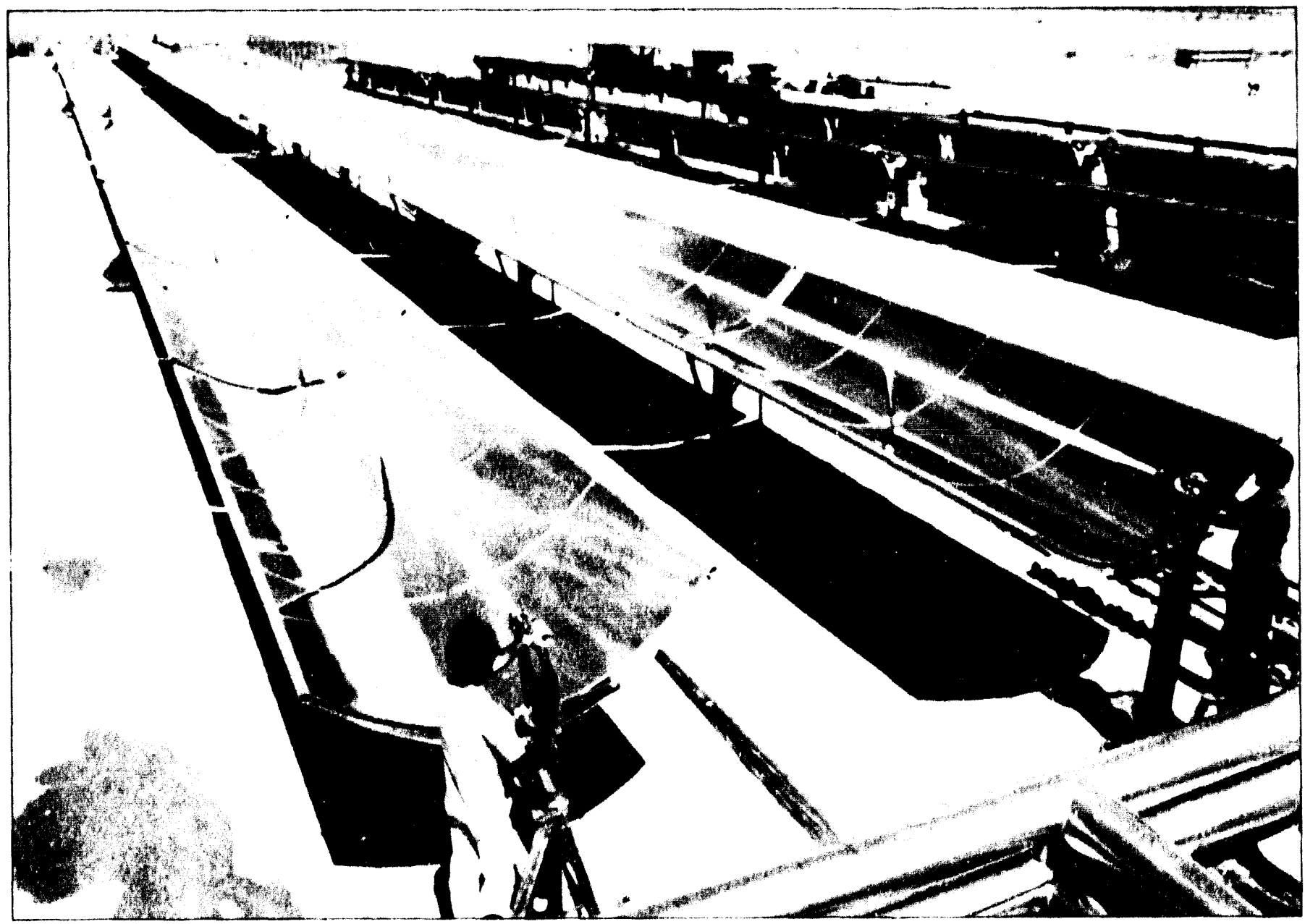

Parabolic troughs (high-temperature solar thermal collectors) operating at a Solar Electric Generating System (SEGS) plant in Kramer Junction, California. 


\section{Appendix $F$ \\ Solar Collector Installed Capacity and Energy Production in the United States}

Information on the amount of solar collectors, solar thermal, and photovoltaics shipped for installation has been reported in this series of reports, "Solar Collector Manufacturing Activity." Solar thermal collectors are quantified by area (square feet). Photovoltaic colls and modules are quantified by the amount of electrical capacity (peak walts).

Since 1974, approximately 212 million square feet of solar thermal collectors were shipped for eventual installation in the United States (Table F1). Solar thermal collectors are grouped into three categories: low-temperature, medium-temperature, and high-temperature. Presuming an overall efficiency of 50 percent for all three categories and a 1,50) Btu per square foot average daily insolation, the potential thermal energy production from the 212 million square feet of solar thermal collectors is 0.058 quadrillion Btu (quads) in 1992.

An efficiency of 50 percent for solar thermal collectors exposed to 1,50) Btu insolation is a simplified approach for this energy calculation. Low-temperature and hightemperature collectors have been rated at more than 50) percent efficient, and medium-temperature collectors are generally less than 50 percent efficient. A mildly cloudy day produce's about $1,5())$ Btu of insolation onto an area of 1 square foot.

In 1991, U.S. nonutility power producers reported installed capacity of 360 megawatts and gross electricity generation of 779 million kilowatthours (the thermal energy equivalent is 0.(X)8 Quad) from solar thermal collectors. Ninety-eight percent of the installed capacity was SECS I-IX (nine operating Solar Electric Generating System plants in southern California with an installed capacity of 354 megawatts). A 10th SECS plant (SEGS X) was never constructed as planned in

\section{Table F1. Annual Photovolialc and Solar Thermal} Domestlc Shipments, 1974-1992

\begin{tabular}{|c|c|c|}
\hline & Domest! & ipments" \\
\hline Year & $\begin{array}{l}\text { Photovoltaic } \\
\text { (peak } \\
\text { kilowatts) }\end{array}$ & $\begin{array}{l}\text { Solar Therma } \\
\text { (thousand } \\
\text { square leet) }\end{array}$ \\
\hline Total, 1974-1992 & 63,593 & 212,471 \\
\hline 1992 & 5,760 & 6.770 \\
\hline 1991 & 6,035 & 6.242 \\
\hline 1990 & 6,293 & 11,164 \\
\hline$\ldots \ldots$ & 5,462 & 11,021 \\
\hline 1988 & 4,318 & 8.016 \\
\hline 1987 & 3,029 & 7,087 \\
\hline$\ldots \ldots$ & 3,224 & 9,136 \\
\hline$\ldots \ldots \ldots$ & 4.099 & E19,166 \\
\hline$\ldots \ldots \ldots$ & 7,759 & 16,843 \\
\hline 1983 & 10,717 & 16,669 \\
\hline 1982 & 6.897 & 18,166 \\
\hline 1981 & 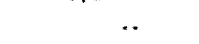 & 19,362 \\
\hline$\ldots \ldots \ldots$ & .. & 18.283 \\
\hline 1979 & .. & 13,396 \\
\hline$\ldots \ldots$ & .. & 10,020 \\
\hline 1977 & .. & 10,312 \\
\hline 1976 & .. & 5,801 \\
\hline 1975 & .. & 3,743 \\
\hline 1974 & .. & 1,274 \\
\hline
\end{tabular}

${ }^{a}$ Total shipments minus export shipments.

$E$ = Estimated data (see Appendix A, pages 24 and 25).

.. - Not applicable.

Sources: 1974-1977-Federal Energy Administration telephone survey. 1978-1984-Energy Information Administration, Form ElA.63, "Annual Solar Thermal Collector and Photovoltaic Module Manufacturers Survey." 1985.1992-Energy Information Administration, Form CE-63A, "Annual Solar Thermal Collector Manufacturers Survey," and Form CE.63B. "Annual Photovoltaic Module/Cell Manutacturers Survey." 
1991. Solar inslalled capacity from nonutility power prodicers in 1492 has nol yot buen publishid, but it should be abuut the sime as in 1441.

Since 1982, approximately 64 poak megawalls of photo. voltaic cells and mextules were shipped for eventwal installation in the United States Thable 111 . Asstiming a 27.5 percent capacity factor, the pefential energy production from the of peak megawalls is 155 million kilowatthours of electricity. This is equivalent 10 (1)(x)2 Quad of thermal energy in 1992, using. a thermal con version rate of 10,352 Btu per kilowatthour of clectricity genoration?

U.S. electric utilities reperted that nel electric generation from photovollaic modules was 3.2 milloun kilo watthours in 1992* (Table 12). Net generalion is groms generation minus plant use by all clectric utility awned plants.

\section{Table F2. U.S. Uilitity Net Electricliy Generation from Solar Energy, 1992}

(Thousand Kilowatthours)

\begin{tabular}{|c|c|c|}
\hline Utillity & $\begin{array}{l}\text { Plant } \\
\text { (State) }\end{array}$ & $\begin{array}{c}\text { Net } \\
\text { Generation }\end{array}$ \\
\hline $\begin{array}{l}\text { Sacramento Municipal } \\
\text { Utility District }\end{array}$ & $\begin{array}{c}\text { Solar } \\
\text { (California) }\end{array}$ & 2.467 \\
\hline Austin Electric & $\begin{array}{c}\text { Decker Creok } \\
\text { (Texas) }\end{array}$ & 369 \\
\hline Pacific Gas \& Electric & $\begin{array}{l}\text { PVUSA } 1 \\
\text { (Calitornia) }\end{array}$ & 322 \\
\hline Virginia Electric Power & $\begin{array}{l}\text { North Anna } \\
\text { (Virginia) }\end{array}$ & 11 \\
\hline Total & & 3,169 \\
\hline
\end{tabular}

Source: Energy Information Administration, Electric Power Monthly, April 1993, DOE EIA 0226(93/04), Table 64
Fstimated U.S whar electrictty generalion was 437.2 million kilowatthours in l(x)? Overall, milimated whlar energy production was ll.k Quad, and adjusted fotal

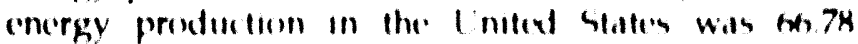
Quads (lable 13$)$

\section{Table F3. Estimated U.S. Solar and Total} Energy Production, 1992

(Quadrillion Btu)

\section{Activity, Production Sector, and Soler Energy Source}

\section{Energy}

Production

Production to Generate Electricity

Electric Utilites

Photovoltaic

Nonutility Power Producers

Solar Thermal Electric

End Users

Photovoltaic

Production to Generate Thermal Energy

End Users

Solat Thermal

Estimated Solar Energy Production

Adjuated Production Eatimate

"Adjusted total is the sum of 1 LA s tolat energy production ustimate of 6512 Quadrillion Blu (Annual Fnergy Review 1992. Table 1 2) and $O O f$ Duadrillion Btu estimatod for solar energy production

(5) = Less than 0005 quadrilion Biu

Sources Energy Intormation Administration ( $(\mathbb{A})$. Form CE 63A. Annual Solar Thermal Collector Manufacturers Survey," and Form CE 63B. Annual Photovoltaic Module Cell Manulacturers Survey" EIA, form EIA 759. Monthly Power Plant Report "EIA. Annual Energy Review 1992 (June 1993), Table 12 and Tabie 812

\footnotetext{
"Department of Energy, "The Potential of Renewable Energy, An Interlaboratory White l'aper" (March 1Wx)1, P C.5

'ElA. Annual Inergy Reture 1993 (June 1943), Table A7

"EIA, Form RIA-774, "Monthly l'ower llant Repurt"
} 
Glossary 


\section{Glossary}

Alr Collector: A medium-temperature solar thermal collector, employed predominantly in space-heating applications, which uses pumped air as the heattransfer medium.

Amorphous Silicon: An alloy of silica and hydrogen, with an irregular internal atomic arrangement, that can be deposited in thin-film layers (a few micrometers in thickness) by means of a number of deposition methods to produce thin-film photovoltaic cells on glass, metal, or plastic substrates.

Btu (British Thermal Unit): A standard unit for measuring the quantity of heat energy equal to the quantity of heat required to raise the temperature of 1 pound of water by 1 degree Fahrenheit.

Cast Sllicon: Crystalline silicon obtained by pouring pure molten silicon into a vertical mold and adjusting the temperature gradient along the mold volume during cooling to obtain slow, vertically advancing crystallization of the silicon. The polycrystalline ingot thus formed is composed of large, relatively parallel, interlocking crystals. The cast ingots are sawed into wafers for further fabrication into photovoltaic cells. Cast-silicon wafers and ribbon-silicon sheets fabricated into cells are usually referred to as polycrystalline photovoltaic cells.

Concentrator: $A$ reflective or refractive device that focuses solar rays onto an area smaller than the reflective or refractive surface, resulting in higher intensity solar rays at the point of focus.

Consumer Goods: Goods such as calculators, computers, toys, and watches that are powered by photovoltaic cells and modules.

Evacuated-Tube Collector: A solar thermal collector in which the collector fluid flows through an absorber tube that is contained inside an evacuated glass cylinder.

Export (solar): A shipment of solar thermal collectors and/or photovoltaic devices sent from the United States and any of its territories to a foreign country.
Flat-Plate (pumped): A medium-temperature solar thermal collector, typically made with a metal frame, glazing, absorbers (usually metal), and insulation, that uses pumped liquid as the heat-transfer medium; predominately used in water-heating applications.

Generation (Electricity): The process of producing electric energy by transforming other forms of energy; also, the amount of electric energy produced, expressed in watthours (Wh).

Gross Generation: The total amount of electric energy produced by the generating units at a generating station or stations, measured at the generator terminals.

High-Temperature Collector: A solar thermal collector that generally operates at temperatures above 180 degrees Fahrenheit.

Import (solar): A shipment of solar thermal collectors and/or photovoltaic devices into the United States and any of its territories from foreign countries.

Integral Collector Storage (ICS): A solar thermal collector in which incident solar radiation is absorbed direclly by the storage medium.

Kilowatthour (Kwh): One thousand watthours.

Liquid Collector: A medium-temperature solar thermal collector, employed predominantly in water heating, which uses pumped liquid as the heat-transfer medium.

Low-Temperature Collector: A solar thermal collector that generally operates at temperatures below 110 degrees Fahrenheit.

Medium-Temperature Collector: A solar thermal collector that generally operates in the temperature range of 140 degrees Fahrenheit to 180 degrees Fahrenheit but can also operate at temperatures as low as 110 degrees Fahrenheit.

Net Generation: Gross generation less the electric energy consumed at the generating station for station use. 
One Sun: Natural solar insulation falling on an object without concentration or diffusion of the solar rays.

Original Equipment Manufacturer (OEM): A nonphotovoltaic manufacturer that combines photovoltaic technology into existing or newly developed product lines.

Parabolic Dish: A high-temperature (above 180) degrees Fahrenheit) solar thermal concentrator, generally bowlshaped, with the capacity for tracking the sun using two axes of rotation.

Parabolic Trough: A high-temperature (above 180) degrees Fahrenheit) solar thermal concentrator with the capacily for tracking the sun using one axis of rotation.

Peak Kilowatt: One thousand peak watts.

Peak Megawatt: One million peak watts.

Peak Watt: A manufacturer's unit indicating the amount of power a photovoltaic cell or module will produce at standard test conditions (normally 1,000 watts porr square meter and 25 degrees Celsius).

Photovoltaic Cell: An electronic device consisting of layers of semiconductor materials fabricated to form a junction (adjacent layers of materials with different electronic characteristics) and (lectrical contacts, and being capable of converting incident light directly into electricity (direct current).

Photovoltaic Module: An integrated assembly of interconnected photovoltaic cells designed to deliver a selected level of working voltage and current at its output terminals, packaged for protection against environmental degradation, and suited for incorporation in photovoltaic power systems.

Ribbon Silicon: Sheets of crystalline silicon fabricated by a variety of solidification (crystallization) methods whereby thin silicon sheets are withdrawn from a pool of relatively pure molten silicon. The methods include: edge-defined, film-fed growth (EFG) and dendritic-web growth.

Single-Crystal Silicon: An extremely pure form of crystalline silicon produced by dipping a single crystal sced into a pool of molten silicon under high vacuum conditions and slowly withdrawing a solidifying single crystal boule (rod) of silicon. The boule is sawed into thin silicon wafers and fabricated into single-crystal photovoltaic cells.

Solar Thermal Collector: A device designed to receive solar radiation and convert it into thermal energy. Normally, a solar thermal collector includes a frame, glazing, and an absorber, together with appropriate insulation. The heat collected by the solar thermal collector may be used immediately or stored for later use.

Special Collector: An evacuated tube collector or a concentrating (focusing) collector. Special collectors operate in the temperature range from just above ambient temperature (low concentration for pool heating) to several hundred degrees Fahrenheit (high concentration for air conditioning and specialized industrial processes).

Survey Frame: The list of companies to which survey forms are sent.

Thermosiphon System: A solar collector system for water heating in which circulation of the collection flitid through the storage loop is provided solely by the temperature and density difference between the hot and cold fluids.

Watthour (Wh): An electrical energy unit of measure equal to 1 watt of power supplied to, or taken from, an electric circuit steadily for 1 hour. 

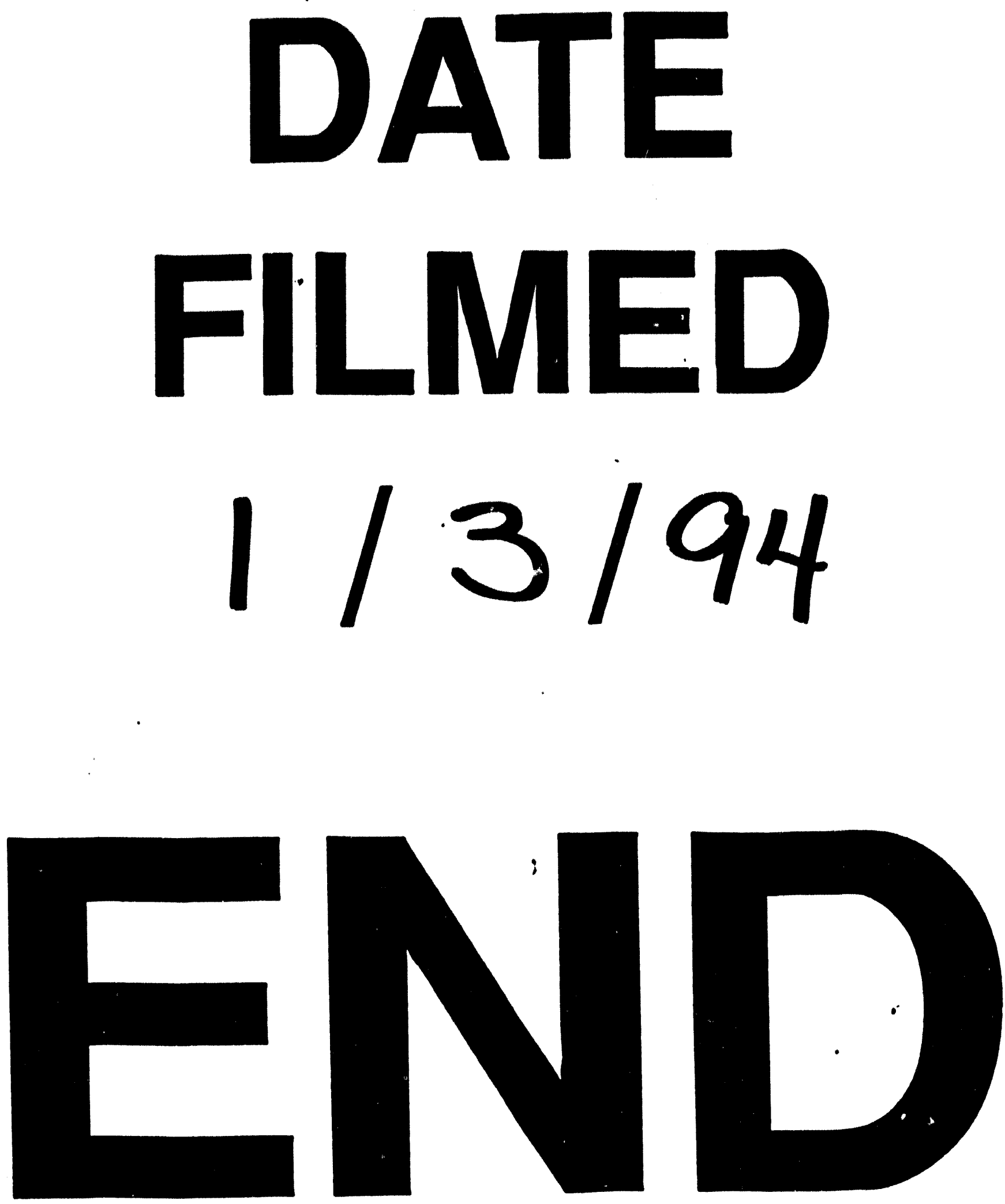